\title{
GENDER AND CONSUMERISM IN NICKOLAS MURAY'S PHOTOGRAPHY FOR
}

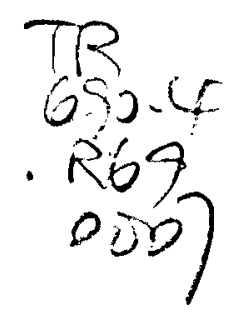

\author{
MCCALL'S MAGAZINE, 1933-1945
}

by

Katherine Roze B.F.A, NSCAD University, Halifax, Nova Scotia, 2003

\author{
A thesis project \\ presented to \\ Ryerson University, Toronto, Ontario and
}

George Eastman House International Museum of Photography and Film Rochester, New York

in partial fulfillment of the

requirements for the degree of

Master of Arts

in the program of

Photographic Preservation and Collections Management

Toronto, Ontario, Canada, 2007

(C) Katherine Roze 


\section{Author's Declaration}

1 hereby declare that I am the sole author of this thesis.

I authorize Ryerson University and George Eastman House International Museum of Photography and Film to lend this thesis to other institutions or individuals for the purpose of scholarly research.

I further authorize Ryerson University and George Eastman House International Museum of Photography and Film to reproduce this thesis by photocopying or by other means, in total or in part, at the request of other institutions or individuals for the purpose of scholarly research. 


\section{Abstract}

GENDER AND CONSUMERISM IN NICKOLAS MURAY'S PHOTOGRAPHY FOR MCCALL'S MAGAZINE, 1933-1945

Katherine Roze

Master of Arts, 2007

Photographic Preservation and Collection Management

Ryerson University, Toronto, Ontario and George Eastman House International Museum of Photography and Film, Rochester, New York

This thesis examines aspects of gender and consumer culture in Nickolas Muray's photographs for McCall's magazine from 1933 to 1945 . It emphasizes the fluidity of meaning from image content to magazine context and includes two image indexes of Muray's images for McCall's from 1933 to 1945 . One features original photographs and the other, published images. McCall's was a mass circulating women's magazine designed for the middle class homemaker. Muray's photographs for McCall's had the dual responsibility of representing the magazine's identity and the reader's idealizations. His images reflected expectations and perpetuated stereotypes of the American woman. At times, her role embodied traditional female values and at other times, it embraced modern womanhood and consumer culture. The latter was continuously amplified by the context of the magazine. These aspects of her role did not conflict. Rather, they complemented one another and characterized the diversity and limitations of her identity. 


\section{Acknowledgments}

It is a pleasure to have the opportunity to thank the many individuals who have helped and supported me throughout this project. My first debt is to my thesis advisor, Bleu Cease, who provided insight, support and reassurance in ways that extended far beyond his obligations as an advisor. His presence in this project shaped the course of the research and simultaneously provided the foundation for our friendship.

I am grateful to my professor, Dr. Alison Nordström, for her continuous direction and advice throughout this project both professionally and personally. Her illuminating discussions on the slipperiness of photographic objects opened my mind to a new method of examining cultural history. Robert Burley also provided me with direction and advice during the course of my studies, and grounded my research when needed.

The staff of the George Eastman House International Museum of Photography and Film and the Monroe County Rochester Public Library provided me with a great deal of help. Carol Tuzzeo provided the special permission required to borrow objects from the Rochester Public Library vault so they could be photographed for this project. Joe Struble made accessing Nickolas Muray's carbro prints possible, and Todd Gustavson provided photographic equipment to reproduce $M c$ Call's magazine images.

Although we have never met, I would like to thank Jennifer Scanlon for providing the inspiration for this project, and the late photographer Nickolas Muray, for having left 
his mark on the American advertising industry. I would also like to thank his granddaughter, Mimi Levitt, his former employee, Daniel Jones, and Dr. Solomon Grimberg for the personal communications that provided insight in Muray's personality and professional life.

I am indebted to those who assisted with editing and revisions, most notably from Jennifer LeBlanc, Dr. Amani Whitfield, Vincenzo Pirozzi, and my mother, Dr. Doris LeBlanc. Their patience and attention to detail proved invaluable to this project and to my studies.

I was fortunate to have the support of friends. Jessica Johnston, Sean Corcoran, Ola Dlugosz, Olivia Arnone, Lisa Hennessey and Elizabeth Reilly's many small services amounted to a great help.

Finally, I would like to thank those who were closest to me for the duration of this project. I am most grateful to my parents, Doris LeBlanc and Blair Roze, who provided tremendous support and enthusiasm throughout. I would also like to thank my children, Gwenna and Salvador, who will some day understand the reasons for the long hours we spent apart. 
For my parents, Doris LeBlanc and Blair Roze

And my children, Gwenna and Salvador 


\section{Contents}

Abstract $\quad$ V

Acknowledgments vii

Illustrations $\quad$ xiii

$\begin{array}{ll}\text { Appendices } & \text { XV }\end{array}$

Introduction 1

One Literature Survey 5

Two Profile of Nickolas Muray 15

Three Profile of McCall's 19

Four Selling the Magazine: The Importance of Cover Images 23

Five The Homemaking Dichotomy 31

Six Motherhood and American Families $\quad 41$

Seven Mixed Visions of "Style and Beauty" $\quad 49$

Eight Working Women $\quad 57$

$\begin{array}{ll}\text { Nine Advertising in McCall's } & 67\end{array}$

$\begin{array}{ll}\text { Conclusion } & 75\end{array}$

$\begin{array}{ll}\text { Appendices } & 79\end{array}$

$\begin{array}{lr}\text { Bibliography } & 129\end{array}$ 


\section{Illustrations}

Figures

4.1 Nickolas Muray, frontispiece, McCall's, April 1938

4.2 Neysa McMein, frontispiece, McCall's, March 1938

4.3 Nickolas Muray, frontispiece, McCall's, October 1940

$4.4 \quad$ Nickolas Muray, frontispiece, McCall's, June 1938

4.5 Nickolas Muray, frontispiece, McCall's, December 1940

4.6 Nickolas Muray, frontispiece, McCall's, November 1938

$5.1 \quad$ Nickolas Muray, "Homemaking," McCall's, October 1938

5.2 Nickolas Muray, "Homemaking," McCall's, July 1937

5.3 Nickolas Muray, "Homemaking," McCall's, January 1942

5.4 Nickolas Muray, "Homemaking," McCall's, February 1942

6.1 Nickolas Muray, McCall's Magazine, Night Before Christmas, ca. 193942

6.2 Nickolas Muray, frontispiece, McCall's, January 1940

6.3 Nickolas Muray, McCall's, Homemaking Cover, Packing Trunk, 45 ca. 1937

6.4 Nickolas Muray, "Homemaking," McCall's, January 1940

6.4 Nickolas M uray, McCall's, Homemaking Cover, Family Arriving 46 for the Holidays, ca. 1939

6.6 Nickolas Muray, "Homemaking," McCall's, November 1939

7.1 Nickolas Muray, McCall Mag, Style and Beauty Cover, Fortune Teller 50 Carbro, ca. 1940

7.2 Nickolas Muray, "Style and Beauty," McCall's, August 1940

7.3 McCall's Pattern Illustrations, McCall's, November 1938

$7.4 \quad$ Nickolas Muray, "Style and Beauty," McCall's, November 1938

7.5 Nickolas Muray, "Style and Beauty," McCall's, April 1938 
7.6 Nickolas Muray, "Style and Beauty," McCall's, April 1939

$8.1 \quad$ Nickolas Muray, frontispiece, McCall's, September 1943

8.2 McCall's Pattern Illustrations, McCall's, July 1938

8.3 McCall's Pattern Illustrations, McCall's, September 1942

8.4 Ruzzi Green and Nickolas Muray, "Homemaking," September 1943

8.5 Ruzzi Green and Nickolas Muray, "Style and Beauty," September 194364

9.1 Nickolas Muray, Cream of Wheat, published in McCall's September 68 1938

9.2 Nickolas Muray, Cream of Wheat, Baby's Phone, Carbro, ca. $1935 \quad 69$

9.3 Nickolas Muray, Cream of Wheat, published in McCall's September 69 1938 


\section{Appendices}

A Nickolas Muray's Production for McCall's, 1933-1945

B Known $M c$ Call's photographs by Nickolas Muray for $M c$ Call's, 1933-1945

C Carbro Prints by Nickolas Muray at George Eastman House

115 International Museum of Photography and Film, 1933-1945 


\section{Introduction}

This thesis examines aspects of gender and consumer culture in Nickolas Muray's photographs for McCall's magazine during the Depression and World War II by emphasizing the ways in which meaning changes from image content to magazine context. The photographs selected for this thesis were chosen because they represent the scope of Muray's work for the magazine and, in many cases, because they could be examined in original and published format. Many descriptions include the original and published versions of the one image and the analysis incorporates how changes such as cropping and color shift affected meaning. Included in the appendices are two image indexes. Appendix B identifies Muray's published photographs for McCall's from 1933 to 1945 and appendix $\mathrm{C}$ reproduces carbro prints commissioned by $M c$ Call 's, which are part of the George Eastman House collection.

Throughout the course of this project, I faced the challenge of trying to establish creative authorship in Muray's photographs for McCall's. How much of the pictures were determined by Muray and how much by an art director? As important as this question might be, the answer could not be determined. Therefore, this thesis examines Muray, not 
as a study of a creative entity but as a prolific and important commercial photographer whose work manifested the spirit of his times.

During the 1930s and 1940s, McCall's was a mass-produced women's magazine that had one of the broadest geographic circulations in the United States. For most of this time, Muray was the most prominently featured photographer. As a staff photographer, he had the responsibility of representing the magazine's intentions and the readers' aspirations. His social tableaux reached the homes and minds of millions of women at a time when the Western world faced the challenges of an economic depression and war. Yet, the contents of the photographs seldom alluded to the hardships of the Depression and World War II. Rather, they depicted a utopian vision of women's domestic life amidst the promises of consumer culture.

The point of departure for this project is Jennifer Scanlon's Inarticulate Longings: Ladies' Home Journal, Gender, and the Promises of Consumer Culture.' Scanlon's cultural analysis explores the roles of women as illustrated in the magazine from its creation to the onset of the Depression. Through fiction, advice columns and advertisements, female readers were offered various and sometimes conflicting models of womanhood in an expanding consumer culture. The original intent of this thesis was to examine the theories presented by Scanlon as applied to Muray's photographic images. However, since her book covers a period later than the one examined in this thesis, this book served mainly as a framework for research and analysis.

Muray's artistic abilities and personal style were perhaps the reasons $\mathrm{McCall}$ 's chose him to define their identity. Renowned for his dedication to perfection, Muray

\footnotetext{
' Jennifer Scanlon, Inarticulate Longings: Ladies' Home Journal, Gender, and the Promises of Consumer Culture (New York and London: Routledge, 1995).
} 
worked closely with art directors to ensure that his clients' wishes were always respected. When photographing editorial images for the magazine, he replicated sketches precisely and accurately. ${ }^{2}$ Although commercial imagery required the creative input of various individuals, credit must be given to Muray for projecting the "magic" in the images. ${ }^{3}$

Muray's editorial photographs for McCall's magazine were designed to appeal to an audience of middle-class women. This class delimitation set forth by the magazine proved to be as inclusive as it was exclusive when compared to the actual American population. Based on his images one could imagine that a McCall's woman was American-born, middle-class, and white. She was college educated and cultured, she was also a happily married homemaker with two children, probably one boy and one girl, with whom she spent most of her time. She lived in an urban or suburban home, had all of the basic utilities and purchased her food at the local supermarket yet had a vegetable garden in the summer. She had dated before marriage and now she enjoyed participating in public social activities such as attending or hosting dinner parties and shopping. Economically, and until the American participation in the war, her purpose in the public sphere was limited to that of the consumer and her representation was apolitical. This limited vision of the McCall's woman excluded variations on race, culture, sexual orientation, economic status and geographic location. It also excluded women who chose not to marry, worked, or had many or no children.

This study examines the use of iconography in Muray's images for McCall's from original print to published photograph. Chapters two and three profile the magazine and the photographer; these chapters provide an understanding of the significance of Muray's

\footnotetext{
${ }^{2}$ Daniel Jones, former employee of Nickolas Muray, in discussion with the author, June 2007.

${ }^{3}$ Salomon Grimberg, e-mail message to author, June 19, 2007.
} 
contribution to McCall's. Chapters four through nine deconstruct Muray's images in terms of gender and consumer culture and explore how their inclusion in the larger context of a magazine influences and alters the meaning of the photographs. Chapter four examines the importance of cover imagery in selling the magazine to readers and potential advertisers by representing the contents and the readers' aspirations. Chapters five and six focus on the conflicting ideals of mother and homemaker presented in Muray's images, occasionally embodying traditional ideals of womanhood while at other times embracing consumer culture. This conflict exists because of prevailing values of Victorian motherhood, which advocated simplicity in domesticity and contentment with what you had, and this was better than a wealth of possessions. Chapter seven examines the promises of life and love in Muray's images under the pretext of style and beauty. Chapter eight considers women's economic contribution during the Depression and World War II. Finally, chapter nine makes the connection to advertising imagery.

The McCall's magazine context in which Muray's images inhabit is intrinsic to their understanding. This cultural studies approach to the photographic discourse underlines the fluidity images have from one context to the next. This study contends that Muray's photographs for McCall's depicted an exclusive and complex view of the American woman. At times she maintained traditional values of womanhood within the confines of patriarchy and capitalism yet once placed in a magazine environment, the ideals in the photographs change to become the assurance offered by consumer culture. 


\section{Literature Survey}

Nickolas Muray's images for McCall's magazine can certainly be studied for their own artistic and cultural merit, but such an approach would drastically undermine their raison d'être. A study of how these objects were used involves both the history of the images in question and an understanding of the context in which they appeared. This cultural approach to the photographic discourse is one that has received much attention over the past decade. However, there has been little attention given specifically to the use of photographs in popular women's magazines and none written exclusively on Muray's photographs for McCall's magazine during the Depression and World War II. This literature survey examines some of the writing on this subject including the magazine's history, various angles of research and other texts on photography and Muray.

Jennifer Scanlon's Inarticulate Longings: Ladies' Home Journal, Gender, and the Promises of Consumer Culture ${ }^{I}$ is perhaps the most complete analysis of a woman's magazine in its cultural context. Covering the time between the creation of Ladies' Home Journal to the onset of the Depression, Scanlon traces the cultural history of the

\footnotetext{
1 Jennifer Scanlon, Inarticulate Longings: Ladies' Home Journal, Gender, and the Promises of Consumer Culture (New York and London: Routledge, 1995).
} 
magazine and its content as an artifact of establishing a consumer culture. As a point of departure, many of Scanlon's theoretical examples successfully apply to Muray's photographs; specifically those concerned with the extreme socio-economic shift that occurred at the onset of the Depression. Yet while the status of women normalized after they acquired the vote, ${ }^{2}$ the same cannot be said for magazine imagery and text, both of which changed quite drastically. Departing from the structure inspired by Scanlon's book, the research for this project is based predominantly on visual cues found in Muray's images and within the pages of the magazine.

Frank Luther Mott's A History of American Magazines ${ }^{3}$ documents the history of McCall's magazine. Although his book covers an earlier period than that when Muray was the primary photographer at $M c C$ all's, his book serves as a foundation for many other texts on the history of American magazines. Another such book was Mary Ellen Zuckerman's A History of Popular Women's Magazines in the United States, 1792$1995,{ }^{4}$ which provides a thorough comparison of major women's mass publications. Two books in particular provided a framework for understanding the cultural function of mass media aimed at women, despite being from a time later than the one in question. Nancy A. Walker's Shaping Our Mother's World: American Women's Magazines ${ }^{5}$ and Susan J. Douglas' Where the Girls Are: Growing Up Female with the

\footnotetext{
${ }^{2}$ Jean V. Matthews, The Rise of the New Woman: the Women's Movement in America, 1875-1930, The American Way Series (Chicago: Ivan R, Dee, 2003) 158.

${ }^{3}$ Frank Luther Mott, A History of American Magazines (Cambridge, Massachusetts: Harvard University Press, 1970).

${ }^{4}$ Mary Ellen Zuckerman, A History of Popular Women's Magazines in the United States, 1792-1995 (New York and Oxford: Oxford University Press, 1991).

${ }^{5}$ Nancy A. Walker, Shaping Our Mother's World: American Women's Magazines (Jackson, Mississippi: University of Mississippi, 2000).
} 
Mass Media ${ }^{6}$ both dealt with issues of mass media and American culture beginning with the post-war baby boom.

As for understanding the actual roles of women in culture when these images were made — and not the ones illustrated by women's magazine — this thesis relies on books documenting the development of the status of women. The most complete and condensed book used for this research was S. J. Kleinberg's Women in the United States, 1830-1945. Also quite insightful and pertinent to this angle of research was Jean V. Matthews' The Rise of the New Woman: The Women's Movement in America, 1875$1930 .{ }^{8}$ Both books provided the perspective required to understand the position of women vis-à-vis status and work; that the new woman in society was not necessarily equivalent to the new woman as portrayed in women's magazines.

Perhaps most crucial to comprehending the context in which Muray's images were commissioned is understanding the lives of homemakers, since $\mathrm{McC}$ Call's believed them to be their readership. Three fascinating texts provided historical accounts of American housewives and their work. Ruth Cowan Schwartz' More Work For Mother: The Ironies of Household Technology from the Open Hearth to the Microwave Oven ${ }^{9}$ painted the most complete picture of American housewives during the Depression and World War II by contrasting those living comfortably and those struggling to make ends meet. Equally as valuable, and differing in their approach, were Susan Strausser's Never

\footnotetext{
${ }^{6}$ Susan J. Douglas, Where the Girls Are: Growing Up Female with the Mass Media (New York: Three Rivers Press, 1995).

${ }^{7}$ S. J. Kleinberg, Women in the United States, 1830-1945 (New Brunswick, New Jersey: Rutgers University Press, 1999).

${ }^{8}$ Jean V. Matthews, The Rise of the New Woman: The Women's Movement in America, 1875-1930, The American Way Series (Chicago: Ivan R. Dee, 2003).

${ }^{9}$ Ruth Cowan Schwartz, More Work For Mother: The Ironies of Household Technology from the Open Hearth to the Microwave Oven (New York: Basic Books, 1983).
} 
Done: A History of American Housework ${ }^{10}$ and Glenna Mathews' "Just a Housewife:" The Rise and Fall of Domesticity in America. ${ }^{\text {Il }}$ These works provide historical analyses of the significant changes that occurred in the lives and responsibilities of American homemakers. The evolution of these changes resulted in three main areas of concentration for the homemaker: housekeeper, consumer, and mother. ${ }^{12}$ Mathews contends that although there was discontent in the fifties, the pattern actually began in the twenties and magnified in the thirties when the homemaker's work was devalued economically and she felt deskilled intellectually. ${ }^{13}$

While slightly less related to this particular project, one noteworthy critique of American housewives that cannot be excluded was former McCall's columnist Betty Freidan's The Feminine Mystique. ${ }^{14}$ Her groundbreaking and seminal text provides much of our current understanding of the homemaker's role and discontent in the fifties, termed by Freidan as "the problem that has no name." 15

Since parenting was seen as intrinsic to homemaking from $M c$ Call's' perspective in the thirties and forties, understanding American family life is essential as well. Aside from the exceptional vision presenied by Schwartz, ${ }^{16}$ Stephanie Coontz' Marriage, A History: From Obedience to Intimacy or How Love Conquered Marriage ${ }^{17}$ demystifies the structure of American marriages during the Depression and World War II. What is

\footnotetext{
${ }^{10}$ Susan Strausser, Never Done: A History of American Housework (New York: Henry Holt, 2002).

"Glenna Mathews, "Just a Housewife:" The Rise and Fall of Domesticity in America (New York and Oxford: Oxford University Press, 1987).

${ }_{12}^{12}$ Ibid.

${ }^{13}$ Glenna Mathews, "Naming the Problem," in Just a Housewife, 197-222.

${ }^{14}$ Betty Freidan, The Feminine Mystique, introduction by Anna Quindlen (New York and London: W. W. Norton \& Company, 2001).

${ }^{15} \mathrm{Ibid}$.

${ }^{16}$ Ruth Cowan Schwartz, More Work For Mother.

${ }^{17}$ Stephanie Coontz, Marriage, A History: From Obedience to Intimacy or How Love Conquered Marriage (New York: Viking, 2005).
} 
particularly pertinent is the historical account of the "radical idea of marrying for love."18 As for the history of American childhoods, Daniel Beekman's much referenced The Mechanical Baby: A Popular History of the Theory and Practice of Child Raising ${ }^{\prime 9}$ and Joseph E. Illick's American Childhoods ${ }^{20}$ both provide knowledge that greatly paralleled and complemented the texts on homemaking.

With respect to the images of women as used in consumer culture, Naomi Wolf's The Beauty Myth: How Images of Beauty Are Used Against Women ${ }^{2 l}$ provides a history and a critique of images of women in the mass media. In her text, she contends that after the invention of photography, mass media imagery created our understanding of beauty ideals by which women are compared. Joan Jackobs Brumberg's The Body Project: An Intimate History of American Girls ${ }^{22}$ complements Wolf's text by providing historical accounts of the impact such images had in changing women's behavior. As the title suggests, body projects are media-influenced endeavors that encourage women to give more attention to appearance and hygiene through increased consumption. One noteworthy critique of Wolf's theories on the cultural creation of the beauty index is Nancy Etcoff's Survival of the Prettiest: The Science of Beauty. ${ }^{23}$ Etcoff counterbalances theories that beauty ideals are largely cultural creations with theories that they are instead fundamentally part of natural and sexual selection and contribute to the survival of the

\footnotetext{
${ }^{18}$ Stephanie Coontz, "The Radical Idea of Marrying for Love," in Marriage, A History, 15-23.

${ }^{19}$ Daniel Beekman, The Mechanical Baby: A Popular History of the Theory and Practice of Child Raising ((Westport: Connecticut: Lawrence Hill \& Company, 1977).

${ }^{20}$ Joseph E. lllick, American Childhoods (Philadelphia: University of Pennsylvania Press, 2002).

${ }^{21}$ Naomi Wolf, The Beauty Myth: How Images of Beauty Are Used Against Women (New York: W. Morrow, 1991).

${ }^{22}$ Joan Jackobs Brumberg, The Body Project: An Intimate History of American Girls (New York:

Random House, 1997).

${ }^{23}$ Nancy Etcoff, Survival of the Prettiest: The Science of Beauty (New York: Anchor Books, 1999).
} 
species. She believes that the beauty index is grounded in nature and only peripherally influenced by culture.

A historical account of how images in the past mirrored culture rather than changed behavior is examined in Carolyn Kitsch's The Girl on the Magazine Cover: The Origins of Visual Stereotypes in American Mass Media. ${ }^{24}$ This book describes the history of representational trends and how they relate to cultural mores and values of the time. Although the time frame covered in this book ends before the Depression, this book provides valuable insight on the true woman versus new woman dichotomy. Another similar work is Marjorie Ferguson's essay “Imagery and Ideology: The Cover Photographs of Traditional Women's Magazines" 25 which provides a critique of the visual stereotypes of women in front page images used to sell popular women's magazines.

There are numerous books on consumer culture as well as essays and critical writings. Three that were particularly helpful in historically contextualizing the establishment of the female consumer were Thomas Hine's I Want That: How We All Became Shoppers, ${ }^{26}$ Pamela Klaffke's Spree: A Cultural History of Shopping ${ }^{27}$ and Rachel Bowlby's Carried Away: The Invention of Modern Shopping. ${ }^{28}$ Hine's text places particular emphasis on how men and women differ in their approach to shopping while Klaffke and Bowlby both focus on the role shopping had in liberating women. They

\footnotetext{
${ }^{24}$ Carolyn Kitsch, The Girl on the Magazine Cover: The Origins of Visual Stereotypes in American Mass Media ((Chapel Hill and London: University of North Carolina Press, 2001).

${ }^{25}$ Marjorie Ferguson, "Imagery and Ideology: The Cover Photographs of Traditional Women's Magazines," in Hearth and Home: Images of Women in the Mass Media, eds. Gaye Tuchman, Arlene Kaplan Daniels and James Benét, 97-115 (New York: Oxford University Press, 1978).

${ }^{26}$ Thomas Hine, I Want That: How We All Became Shoppers (New York: HarperCollins, 2002).

${ }^{27}$ Pamela Klaffke, Spree: A Cultural History of Shopping (Vancouver: Arsenal Pulp Press, 2003).

${ }^{28}$ Rachel Bowlby's Carried Away: The Invention of Modern Shopping (New York: Columbia University Press, 2001).
} 
contend that shopping gave them a place in the public sphere and economic world. Klaffke's text is much more embedded in the present while Bowlby's explores the history of women's role in shopping and consumer culture. Along the same lines, Jennifer Scanlon's The Gender and Consumer Culture Reader ${ }^{29}$ provides a selection of essays which examine various aspects of gender in consumer culture that are often overlooked in broad historical accounts.

Two exemplary books on the cultural history of advertising in America are Jackson Lears' Fables of Abundance: A Cultural History of Advertising in Modern America $^{30}$ and Roland Marchand's Advertising the American Dream: Making Way for Modernity. ${ }^{31}$ Although gender is not their focus, both provide the basis for a contemporary understanding of the history of advertising. Of particular interest is Lears' discussion of the relationship between fine art and imagery in advertising. Related to this, Patricia Johnston's Real Fantasies: Edward Steichen's Advertising Photography ${ }^{32}$ analyses Steichen's advertising images and their relationship to his artistic practice and the artistic culture of the time; she proposes that although his images were commercial in intent, they can nevertheless be discussed artistically. Equally as insightful as the previous two, and often seeming like an abridged version of both, is Juliann Sivulka's Soap, Sex and Cigarettes: A Cultural History of American Advertising. ${ }^{33}$ While Lears' and Marchand's books offered a large number of theories on the history of advertising,

\footnotetext{
${ }^{29}$ Jennifer Scanlon, ed, The Gender and Consumer Culture Reader (New York: New York University Press, 2000).

${ }^{30}$ Jackson Lears, Fables of Abundance: A Cultural History of Advertising in Modern America ((New York: Basic Books, 1994).

${ }^{31}$ Roland Marchand, Advertising the American Dream: Making Way for Modernity, 1920-1940 (Berkley, Los Angeles and London: University of California Press, 1985).

${ }^{32}$ Patricia Johnston, Real Fantasies: Edward Steichen's Advertising Photography (Berkley: University of California Press, 1997).

${ }^{33}$ Juliann Sivulka, Soap, Sex and Cigarettes: A Cultural History of American Advertising (New York: Wadsworth Publishing Company, 1998).
} 
Sivulka put those theories into practice and applied them to a multitude of images, slogans and jingles. Her book also includes a series of graphic timelines, which mark memorable moments in American history, turning points in advertising history and the birth of important products and slogans.

Surprisingly unhelpful was Tom Reichert's The Erotic History of Advertising. ${ }^{34}$ Despite having dedicated a section specifically to the use of love in McCall's magazine during the Depression, his generalized theories applied only to a select few of Muray's images in $M c$ Call's. In addition, some of his generalizations on gender-specific advertising conflicted quite clearly with $M c$ Call's magazine advertising content, for instance, his assumption that sexual arousal by the use of nude depictions of the opposite sex was used not to promote brand association and sell products to women, but to men. Yet throughout the war, Cannon towels ran a series of full page ads on the inside cover of the magazine which featured buff nude soldiers in social tableaux such as towel fights in communal showers.

Focusing specifically on the use of photographs in advertising and magazine imagery, Robert Sobieszek's The Art of Persuasion: A History of Advertising Photography $y^{35}$ remains the authoritative text that deals specifically with the historical evolution of the photographic image in advertising. By prioritizing the image, Sobieszek maps out stylistic trends while highlighting the technical evolutions occurring with the photographic process.

With respect to the use of colour photographs in popular culture, Sally Stein's dissertation entitled "The Rhetoric of the Colorful and the Colorless: American

\footnotetext{
${ }^{34}$ Tom Reichert, The Erotic History of Advertising (Amherst, Yew York: Prometheus Books, 2003).

${ }^{35}$ Robert Sobieszek, The Art of Persuasion: A History of Advertising Photography (New York: Harry N. Abrams, 1998).
} 
Photography and Material Culture between the Wars" ${ }^{36}$ provides an in-depth examination of the use of colour photographic technology during the Inter-War period. Specifically related to process and practice, Victor Keppler's The Eighth Art: A Life of Color Photography ${ }^{37}$ is perhaps the most accurate account of the carbro process in commercial practice during the Depression. This process was used by Muray throughout the time period examined in this study.

Finally, for a biographical account of the photographer himself, Salomon Grimberg's I Will Never Forget You: Frida Kahlo and Nickolas Muray ${ }^{38}$ is the only published text that extends beyond articles and interviews in magazines about Muray. Although focused on the relationship and communication between Muray and his lover Frida Kahlo, the book does include a chronological sketch of Muray's life. To establish some understanding of his working environment, the documentation of communication with those who knew, worked with and studied with him is invaluable.

This literature survey indicates the multiple areas of research available to help understand one collection of images by one photographer, for one magazine over a given period of time. Certainly, more angles could have been adopted, even within the parameters of gender and consumerism in Nickolas Muray's photographs for McCall's magazine. Understanding how photographs were used in a cultural context requires the acceptance that meaning is not intrinsic to an image but is in fact malleable, changing, and dependent on the context in which it appeared, the reasons it was made and the cultural context it inhabits.

\footnotetext{
${ }^{36}$ Sally A. Stein, "The Rhetoric of the Colorful and the Colorless: American Photography and Material Culture between the Wars" (PhD diss., 1991).

${ }^{37}$ Victor Keppler, The Eighth Art: A Life of Color Photography (London: Chapman, 1939).

${ }^{38}$ Salomon Grimberg, I Will Never Forget You: Frida Kahlo and Nickolas Muray (San Francisco: Chronicle Books, 2004).
} 


\section{Profile of Nickolas Muray}

Nickolas Muray, the fourth of five children, was born Miklós Mandl in 1892 in Zseged, Hungary into a Jewish family. ${ }^{1}$ The family relocated to Budapest where his father, a postal worker, considered him to be the brightest of his children and wanted him to become a lawyer. However, Muray had other dreams and began his apprenticeship in an artist's studio at the age of twelve. He later entered the Budapest Graphic Art School and studied photography, lithography and photo-engraving. This was followed by a yearlong employment at Weinerwurm \& Co. photo-engravers. Continuing along the same path, he moved to Munich to study colour separation and then to Berlin to study photochemistry, colour filtration and colour photo-engraving. This earned him his International Engravers Certificate. Armed with the certificate, Muray immigrated to the United States in 1913 and a few years later became an American citizen. ${ }^{2}$

Muray's photo-engraving career continued after his arrival in the United States where he worked for Condé Naste. Here, he did colour separation negatives for Vanity Fair in New York. Influenced either by the magazine he worked for or his friend Edward

\footnotetext{
'Chronology of Nickolas Muray" in I Will Never Forget You: Frida Kahlo and Nickolas Muray (San Francisco: Chronicle Books, 2004), 109.

${ }^{2}$ Ibid.
} 
Steichen, or perhaps simply by his creative circle of friends, Muray's personal photographic output increased after 1913 while he developed the style that would soon make him famous. During the 1920s, Muray opened his own studio where his talent for celebrity photography earned him a reputation among the literary and artistic community in New York and beyond. While engaging in some commercial work, Muray's career focused on black and white glamour portraiture, particularly in the areas of theatre and dance, taking more than ten thousand photographs during this time. ${ }^{3}$ His approach to the genre helped codify that era's artistic style of celebrity portraiture.

The stock market crash of 1929 shifted Muray's creative output to commercial and editorial magazine photography. ${ }^{4}$ Editorial photography was understood as commissioned work for parts of the magazine such as the front page, stories and articles. Commercial photography was for advertisements. McCall's magazine used Muray's editorial photographs to differentiate sections of the magazine by featuring social tableaux or still lives.

At the same time that the bulk of Muray's output shifted from celebrity portraiture to advertising and magazine photography, his primary production method evolved from black-and-white gelatin silver prints and negatives to colour carbro prints from colour separation negatives. Muray became a master of the carbro process; in 1931, he photographed the first commercial colour carbro ever reproduced in a magazine. ${ }^{5}$ The photograph consisted of twenty-one models arranged around a pool for a two-page Ladies' Home Journal spread.

\footnotetext{
${ }^{3}$ Jbid.

${ }^{4}$ Ibid., 110.

5 Ibid.
} 
The carbro process is a laborious additive photographic process and the practitioner is necessarily meticulous. ${ }^{6}$ It requires a special camera that takes three blackand-white exposures on panchromatic film through red, green and blue filters or on dyed panchromatic film in these colours. Following this, the separation negatives are used to make black and white separation prints on fiber-based barita paper. Following a series of exact steps involving image transfers, bleaching and the addition of colour, a final print is made by assembling the coloured gelatins that began as separation prints onto one piece of paper. The colour, which was added to the process during the first image's support transfer, comes from manufactured coloured tissues in the complementary colours of cyan, magenta and yellow. Initially, to reproduce the prints in a magazine, the prints were re-photographed by a colour engraver and matched to replicate the original print. However, after about 1937, many photographers, including Muray, produced their own separation negatives or bromides to the printers. ${ }^{7}$ This process greatly facilitated the process and increased accuracy in reproducing the colours intended by the photographer. Muray began photographing for McCall's in 1933, and in the ten-year period of 1934 to 1944 , he was their most prominent photographer. McCall's self-proclaimed "Three Magazines in One" wanted to be a woman's complete cultural resource and divided its pages appropriately into three sections. Each of the sections had a cover: the first for news and fiction used the front cover, the second for homemaking, and the third for style and beauty. The front covers were most often portraits while the inside covers were mostly social tableaux. Muray's career peaked with McCall's in 1940 when he

\footnotetext{
${ }^{6}$ A detailed description of the carbro process for the commercial photographer is given by Victor Keppler in his "Carbro Printing," in The Eighth Art: A Life of Color Photography (London: Chapman, 1939), 102-134.

${ }^{7}$ Daniel Jones, former employee of Nickolas Muray, in discussion with the author, June 2007.
} 
photographed eighteen of the thirty-six covers that year, half of which were the front covers of the magazine. For a graph of Muray's production for McCall's see appendix A. Muray would continue to photograph for McCall's after the end of World War II, but his production for them diminished considerably and shifted to being primarily food photography and still lives. He continued to be sought out as a celebrity portraitist and his photographic career expanded once again in both skill and subject matter. Little more than a decade later, he adopted the new role of traveling photographer accompanying Dr. Paul Fejos around the world as official anthropological photographer. Throughout his life, and up until his death in 1965, Muray produced an astounding number of images in a variety of photographic genres. 


\section{Profile of 'McCall's'}

McCall's magazine was first published in the fall of 1873 in the United States. ${ }^{1}$ At this time mechanical reproduction technology had increased dramatically. Scottish immigrant and tailor James McCall founded the magazine so that he and his wife could advertise their fashion patterns. ${ }^{2}$ Originally named The Queen: Illustrating McCall's Bazaar Glove Fitting Patterns and later renamed The Queen of Fashion, the magazine was a consumer-based vehicle for fashion advertisement with little other content. Following the death of their founder, a series of financial and managerial struggles resulted in an expansion and diversification of content and an increase in quality. ${ }^{3}$ By 1910, McCall's had successfully become a women's general interest magazine. ${ }^{4}$

Urbanization had made it easier to reach women while advertising revenue had made it possible to sell McCall's below production cost. ${ }^{5}$ By the turn of the century, the

\footnotetext{
' Mary Ellen Zuckerman, A History of Popular Women's Magazines in the United States, 1792-1995 (New York and Oxford: Oxford University Press, 1991), 16.

${ }^{2}$ The sewing machine was invented in the 1940s and fashion patterns in the 1960s, Mary Ellen Zuckerman, A History of Popular Women's Magazines, 4 and 16.

${ }^{3}$ Ibid. 101 .

${ }^{4}$ Ibid., 25.

5 Ibid., 25.
} 
magazine was among the top six mass circulation women's magazines. ${ }^{6}$ The other five were Delineator, Good Housekeeping, Ladies' Home Journal, Pictorial Review, and Women's Home Companion. ${ }^{7}$ Despite an expansion in subject matter, in 1912 McCall's was considered little more than a cheap women's magazine. ${ }^{8}$ It was the least expensive mass circulation women's magazine, costing five cents per issue, while its five major competitors cost fifteen cents per issue. However, it still held the second largest circulation and was one of only two to have broken the million mark selling $1,084,902$ copies that year while its main competitor, Ladies' Home Journal, sold $1,538,360 .{ }^{9}$ Over the next few years, the price increased while the competitor's price decreased resulting in a longstanding ten cents an issue price that remained until World War II.

In the 1920s, McCall's would continue to "grow richer visually and in text," but the stock market crash of 1929 caused some unexpected changes. ${ }^{10}$ During the first years of the Depression, advertising content decreased and the magazine slimmed, though only temporarily. Moreover, the magazine streamlined its content, keeping only what was believed to be of interest to all women. This included features on homemaking, style and beauty, as well as fiction. Content would diversify during World War II and re-include multifaceted versions of womanhood, including married women at work."

In 1927 Otis L. Weise was hired at McCall's; one year later at the age of twentythree he was made editor. ${ }^{12}$ Often referred to as "the boy editor," ${ }^{13}$ he redefined much of

\footnotetext{
${ }^{6}$ Ibid.. 29.

${ }^{7}$ Ibid.

${ }^{8}$ Ibid.

${ }^{9}$ Ibid.

${ }^{10}$ Ibid., 101.

${ }^{11}$ Mary Ellen Zuckerman, “Part II, Women's Magazines 1919-1945," in A History of Popular Women's Magazines, 101-102.

${ }_{12}^{12}$ Time "Man in a Woman's World," 6 January 1947, www.time.com/time/archive.

${ }^{13}$ Mary Ellen Zuckerman, A History of Popular Women's Magazines, 112.
} 
the magazine's identity. In 1932, he made his first big editorial change by dividing the content of the magazine into three sections: "News and Fiction," "Homemaking," and "Style and Beauty." Just under the title on the cover page it stated: "Three Magazines In One." This was to be the new logo for the magazine. Each of the sections had appropriate content and advertising and each section had its own cover. Weise was also responsible for the shift in fiction content, which he believed was too light and sweet. Initially causing as much good as controversy, Weise bought stories that covered taboo subjects, including themes such as adultery. He asked rhetorically "But why should they [women] prefer boy-meets-girls on the bus stories when they know damn well they didn't meet their own husbands that way?"14

Under the direction of Weise, colour photography began to appear to illustrate the various cover sections of McCall's. Many believed photography was the universal language and that, unlike illustration, photographs could better relate to the reader. In addition, photographic reproductions were less expensive to commission than illustrations. McCall's had been reproducing black and white photographs since $1897^{15}$ and reproduced its first colour photograph in the November issue of 1933. Muray was one of the two photographers commissioned for that issue. His "Style and Beauty" section cover featured a portrait of a woman in a red dress admiring her reflection in the mirror.

McCall's readership was, and had for a long time been considered by its editors as white middle-class urban women. ${ }^{16}$ McCall's differed slightly from its competitors

\footnotetext{
${ }^{14}$ Time, "Man in a Women's World," interview with Otis L. Weise, 6 January 1947, www.time.com/time/archive.

${ }^{15}$ lbid.

${ }^{16}$ Mary Ellen Zuckerman, "Reader Demographics," in A History of Popular Women's Magazines, 133.
} 
because it catered primarily to women from smaller urban centers scattered throughout the United States. ${ }^{17}$ Hence, they had the broadest readership and, although fluctuating, the second highest one as well, selling over two million copies a year by World War II. Readership of other magazines such as Ladies' Home Journal and Good Housekeeping's were primarily located in large cities. Demographically, and as surveys conducted by the magazine revealed, $M c$ Call's readership ranged primarily between the ages of twenty-six and forty-five. ${ }^{18}$ Furthermore, younger women were more interested in fiction and beauty advice; older women were concerned with current events and socio-economics. Poorer women preferred fiction, while wealthier women read current events. ${ }^{19}$ Muray's covers for the various sections of the magazine reflected these findings, often featuring women and children on the "Homemaking" covers, unmarried women on the "Style and Beauty" covers, and ageless women of undetermined marital status on the front covers of the magazine.

\footnotetext{
${ }^{17}$ Ibid., 134

${ }^{18}$ Ibid., 133

${ }^{19}$ Ibid., 134
} 


\section{The Importance of Cover Imagery}

Nickolas Muray inaugurated a change for McCall's magazine in April 1938 when for the first time, a photograph was published as the cover image of the magazine. While Muray had been photographing inside covers for McCall's for some time, it was not until 1938 that $M c$ Call's chose to have photographs on its covers. Front cover images were especially important because they had the essential responsibility of selling the magazine. In addition to encouraging sales, front covers had to summarize visually the content of the magazine, represent the reader's aspirations and be appealing to potential advertisers.

To accentuate this change from illustration to photographic depiction, the front cover design was altered. The text area, which included the title, features, issue and price, was reduced to the top third of the page to allow the cover image to gain more prominence. As can be seen in the previous month's layout design of March 1938, the cover illustration encompassed only slightly more than one quarter of the surface area of the front page and was sandwiched between the title, price and issue located above, and the features below. The new design's photographic illustration covered about two thirds of the front page's surface area and all text was relocated above the image. By increasing 


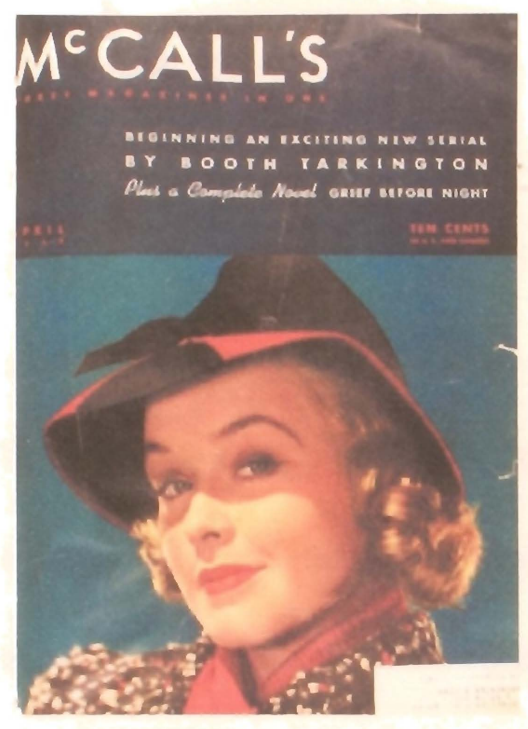

4.1. April 1938

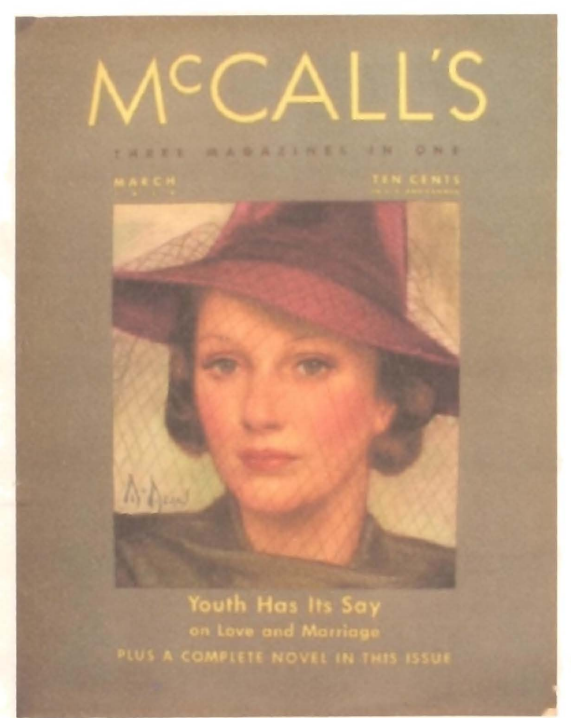

4.2. March 1938

Illustration by Neysa McMein

its size, the layout accentuated the photograph's importance. Curiously, while the dimensions of the image increased, the actual scale of the women's heads in the portraits did not change. Rather, the photographic depictions were simply less tightly cropped than the illustrations and dimension grew to include some of the background. In addition, the orientation of the portraits shifted from vertical to horizontal to fit with the new layout structure. The layout continued to change throughout Muray's time with McCall's and gave increasing importance to the photographic image. By the end of World War II, the text was reduced to a mere one fifth of the front page's surface, located yet again in two locations on the page, while the photographic image gained more prominence than ever before.

While there was a clear and steady rise in the use of colour photographs in magazines in the 1930s, 1936 is generally considered the year the shift from illustration to colour photographic reproduction in popular magazines occurred. McCall's, which had been reproducing photographs since the late nineteenth century and commissioning 
colour photographic reproductions for its "Homemaking" and "Style and Beauty" section covers since November 1933, chose to stay with illustrations on its front covers for another five years. However, by 1940 virtually all McCall's covers, inside and out, were photographic reproductions. Interestingly, 1940 was Muray's peak production year with McCall's photographing on average two of the three covers for each issue including nine of the twelve front covers (see appendix A for a graph of his production, and appendix B and $\mathrm{C}$ for examples).

The August 1940 cover of $M c$ Call's is a half tone reproduction of a colour photograph by Muray. The colour scheme is light blue, dark blue and white. Like the overwhelming majority of $M c$ Call's covers, the subject matter is a portrait of one woman. Twenty-eight of the thirty-nine covers photographed by Muray during the Depression and World War II are portraits of one woman. With no evidence of marital status, the woman, like the perceived readership demographic, could be any age ranging from twenty-five to forty-five. ${ }^{1}$ She is attractive, elegantly dressed-as her white lace gown suggests-and adorned with earrings and a necklace that mimic the aesthetic of traditional Egyptian jewelry. Similarly, her dark brown hair and dark brown eyes lined in black also echo an Egyptian aesthetic. Her bright red lips are posed in a slight smile. She looks out confidently from her place on the magazine cover and confronts the viewer directly. The backdrop is made of the same lace material as her dress. Inside the August 1940 issue, one finds escapes from reality through fictional heroines, articles and recipes destined for the homemaker, fashion and beauty advice, in-style pattern illustrations and a multitude

\footnotetext{
${ }^{1}$ On the perceived readership demographic in McCall's see Mary Ellen Zuckerman, "Reader Demographics," in A History of Popular Women's Magazines in the United States, 1792-1995 (New York and Oxford: Oxford University Press, 1991), 133.
} 
of consumer advertisements. Two of the articles featured in the issue advise on purchasing a pet for your child and how to choose the right bathing suit for your body.

Considering the indicators embedded in the front cover photograph, this woman's agelessness and the absence of any visible sign of marital status such as a wedding band, position her to appeal to the broadest possible female audience based on McCall's readership demographic. ${ }^{2}$ Furthermore, as surveys conducted in the late thirties and forties revealed, younger

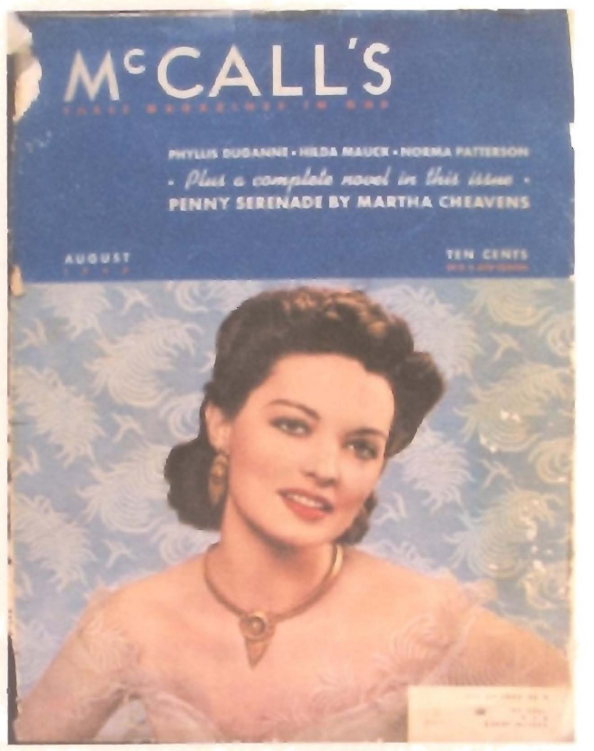

4.3. October 1940 women read more fiction and were interested in beauty while older women read more about current events and homemaking. ${ }^{3}$ As a general interest magazine and a woman's cultural resource, the front cover had to appeal to all of these women. In order to do this, Muray photographed models such as this one. She appears ageless and could represent the entire perceived readership. Moreover, through careful posing, usually involving the hiding of wedding bands, marital status in cover models was easily masked. There were consistent exceptions however as Muray often photographed brides, sometimes accompanied by grooms, for a spring or summer issue. He also occasionally photographed mothers, most often, although not always, during the holiday season, as can be seen in covers June 1938 and December 1940.

\footnotetext{
${ }^{2}$ Ibid.

${ }^{3}$ Ibid.
} 


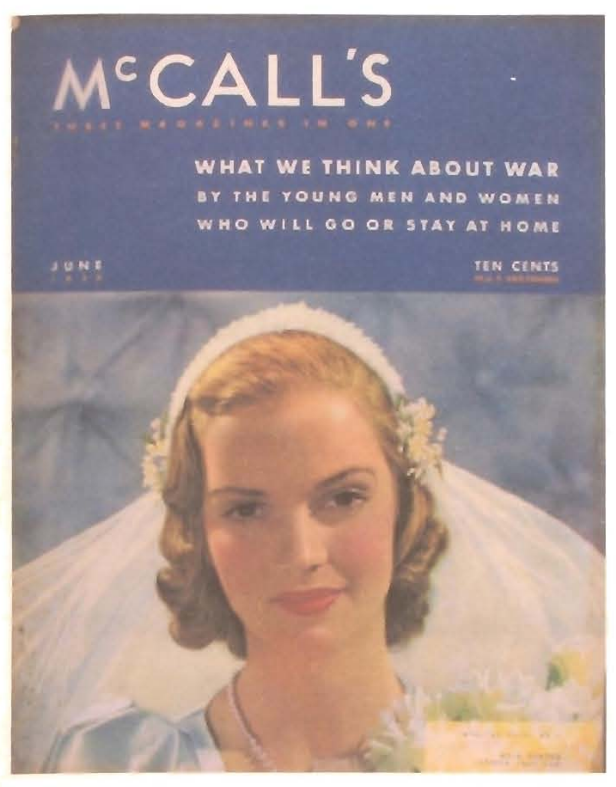

4.4. June 1938

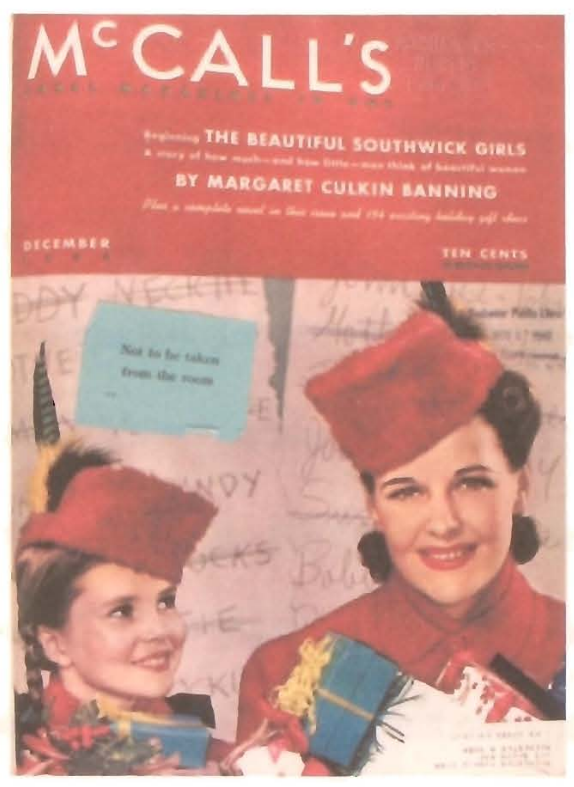

4.5. December 1940

Photographically, Muray bridged two important periods in American history: the

Depression and World War II. However, looking at

Muray's cover images for McCall's in the 1930s,

one could hardly have believed that the nation was

still in the throes of the Depression, albeit in the

process of recovery. One of numerous examples of

this trend is Muray's November 1938 cover

photograph which features an elegantly dressed

woman in modern fall attire wearing a hat and

gloves by designer Lily Daché. Her coat is a somber

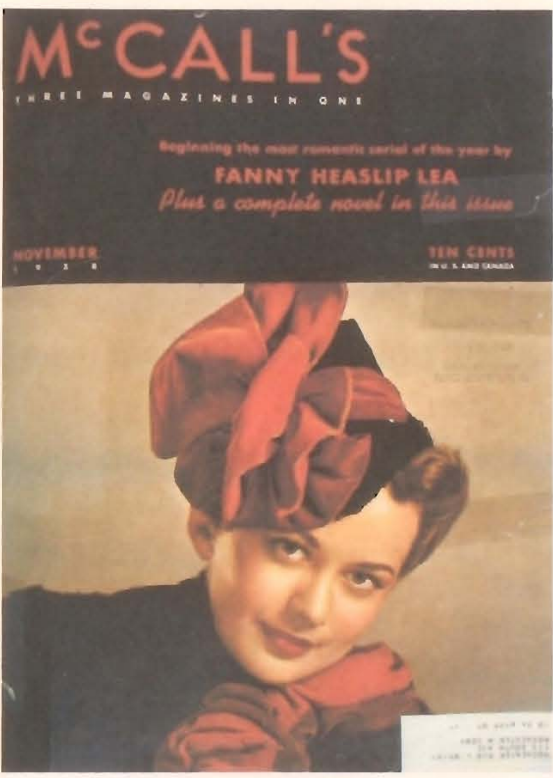

4.6. November 1938

shade, which helps accentuate her deep red designer accoutrement and her lovely face.

Like many of her contemporaries, she too has an ageless face and her marital status is

kept secret inside her gloves. Her graceful appearance reveals none of the hardships that her readership would have witnessed and experienced over the last nine years. Her image 
is a visual paradigm which historian Jackson Lears referred to as a "systematic denial" of hard times in popular women's magazines. ${ }^{4}$

When Muray photographed his model for the cover of the magazine of the November 1938 issue, he would have been photographing a combination of what women were and what women would like to be. As Marjorie Ferguson argues, "her personal importance is stressed by her symbolic dualism in representing both a magazine's identity and its reader idealizations." The cover was designed to display the subject matter of the magazine and the reader's aspirations. In addition to attracting readers, Muray's cover images also had to appeal to potential advertisers since $\mathrm{McCall}$ 's, like its competitors, relied heavily on that revenue to supplement their income. ${ }^{6}$ Advertisers preferred their audience to have a certain level of buying power. ${ }^{7}$ Therefore, if these luxurious women appeared on the cover the magazine, it was implied that similarly affluent women read them. While Muray's model for the November 1938 cover was ageless, she was not classless. She was chosen and adorned to evoke the aspirations of middle class women; a group of women who even during the Depression had great purchasing power and were the nation's consumers because they made the majority of household purchases. ${ }^{8}$

Once the war began, there was a steady rise in patriotic imagery in Muray's photographs for McCall's. This began as a visible increase in the red, white and blue

\footnotetext{
${ }^{4}$ Jackson Lears, Fables of Abundance: A Cultural History of Advertising in Modern America ((New York: Basic Books, 1994). 237.

${ }^{5}$ Marjorie Furguson, "Imagery and Ideology: The Cover Photographs of Traditional Women's Magazines,", in Hearth and Home: Images of Women in the Mass Media, eds. Gaye Tuchman, Arlene Kaplan Daniels and James Benét, 97-115 (New York: Oxford University Press, 1978), 101.

${ }^{6}$ Mary Ellen Zuckerman, A History of Popular Women's Magazines, 25.

${ }^{6}$ The sewing machine was invented in the 1940s and fashion patterns in the 1960s, Mary Ellen Zuckerman, A History of Popular Women's Magazines, 25.

${ }^{7}$ Mary Ellen Zuckerman, A History of Popular Women's Magazines, 134.

${ }^{8}$ On the consumer's importance and primal responsibility see Thomas Hine, I Want That: How We All Became Shoppers (New York: HarperCollins, 2002), 23
} 
colour schemes from 1942 until the end of the war where he photographed such war-time themes as working women using heavy machinery. During the years the United States participated in the war, soldiers replaced men as boyfriends and grooms in Muray's front cover depictions. Yet, despite the increase in wartime imagery, the majority of his cover images for McCall's remained similar to those of the previous era and continued to feature clean and confident context-free women in stylish clothes. Out of the thirty-one front covers photographed by Muray during World War II, there are twenty portraits of a single women, five of a man and women, three of a mother and daughter, one of our girls, one of a women and two soldiers, and one unknown. ${ }^{9}$ Only three of the thirty-one covers are portraits of working women.

Muray's cover for March 1942 was no exception. His image of a glamorous model in black attire and white gloves, wearing an elaborate bracelet and framed by a zebra print background, stayed true to his style of front cover portraiture. The model, like the others, appeared ageless but not classless. She was well dressed and in the latest fashion and jewelry. Like her sisters, she continued to stand for the ideologies of the magazine and the readers' aspirations. The style of glamour photography in which Muray depicted her was a continuation of what originally made him famous in the 1920 s.

In summary, Muray initiated a change in McCall's in April 1938 that would forever alter the magazine's front-page identity. He did so by photographing the first image ever published as the cover of the magazine. He would continue to photograph front covers throughout the remainder of the Depression and World War II. These photographs, used to sell the magazine, had the dual objective of representing the mores

\footnotetext{
${ }^{9}$ McCall's credits the December 1939 front cover to Nickolas Muray even if the page was missing from the magazine used for this research.
} 
and ideals upheld by the magazine as well the readers' desires. The magazine being consumerist in nature, front covers also had to appeal to potential advertisers. The front cover images were a formal invitation to see all of the promises offered inside. Inside the magazine were differing images, articles of fiction and advice on the ideals of womanhood. At times the magazine maintained traditional female values of simplicity in domesticity; at other times it relished the grandeur of consumer culture. 


\section{The Homemaking Dichotomy}

If the gender dichotomy suggested by Jennifer Scanlon still existed a generation later among the pages of popular women's magazines, 'in Nickolas Muray's images for McCall's it is most prominent in the still life and social tableaux that introduced the "Homemaking" section of the magazine. In these editorial photographs, one can see most clearly the different messages women received; at times, they embodied the romantic ethics of traditional womanhood and other times, the modern ideals of women in contemporary culture.

The cult of true womanhood embodied Victorian ideals of femininity; the true woman wanted little more than a happy home and healthy children and was not concerned with, or even interested in, consumerism. ${ }^{2}$ Her depictions in $\mathrm{McC}$ all's supported the ideology that the home could be economically viable, producing useful things such as vegetables and clothing for the family. She reflected wholesome family

\footnotetext{
' Jennifer Scanlon, Inarticulate Longings: Ladies' Home Journal, Gender, and the Promises of Consumer Culture (New York and London: Routledge, 1995), 4.

${ }^{2}$ On true womanhood, see Carolyn Kitsch, "From True Woman to New Woman," 17-36, and "The Modern American Family," 136-159, in The Girl on the Magazine Cover: The Origins of Visual Stereotypes in American Mass Media (Chapel Hill and London: University of North Carolina Press, 2001) and Jennifer Scanlon, Inarticulate Longings, 4 and 50.
} 
values. She was happy with her life as a homemaker. The new woman embraced consumer culture and embodied this as part of her gendered role. ${ }^{3}$ The home was the seat of consumption rather than production. Outside the home, her task as consumer was an important familial responsibility, one that included her in the public sphere and positioned her as an economic member of society. It is important to note that at the time of Muray's entrance as a photographer for McCall's covers, women had long been established as the primary consumers in the home, and as such, were responsible for at least 80 percent of all purchases. ${ }^{4}$

Muray's editorial photograph for the October 1938 "Homemaking" cover of McCall's is an image of a boy and a girl in a domestic setting. In the image, the girl is at the kitchen sink washing a dish with a scrubber while the boy steals icing from the pot found at the table next to the cake. As a result of his mischievous action, the girl is giving him a look of lighthearted scorn. As was common in Muray's images in McCall's in 1938, the colour scheme is red, white and blue. The children in the image are fair-haired, clean and well groomed with the boy's hair being playfully messy. The background displays several steel pots and pans hanging on the wall and hot and cold water taps above two sinks filled with dishes, one clean and one filled with soapy water. The foreground features a clothed table with a cake, a pot of icing and a knife. The primary visual emphasis is the humorous interaction between the boy and girl. The secondary visual emphasis is the freshly iced and delicious looking cake. The physical use of this image was to mark the start of the "Homemaking" section of the magazine. The cultural

\footnotetext{
${ }^{3}$ On true women in consumer culture, see Jennifer Scanlon, "Housekeeping" in Inarticulate Longings, 13 and 172.

${ }^{4}$ Roland Marchand, Advertising the American Dream: Making Way for Modernity, 1920-1940 (Berkeley, Los Angeles and London: University of California Press, 1985), 167.
} 
use of the image was a depiction of ideologies created to appeal to a specific

demographic group of women, that of mothers and homemakers.

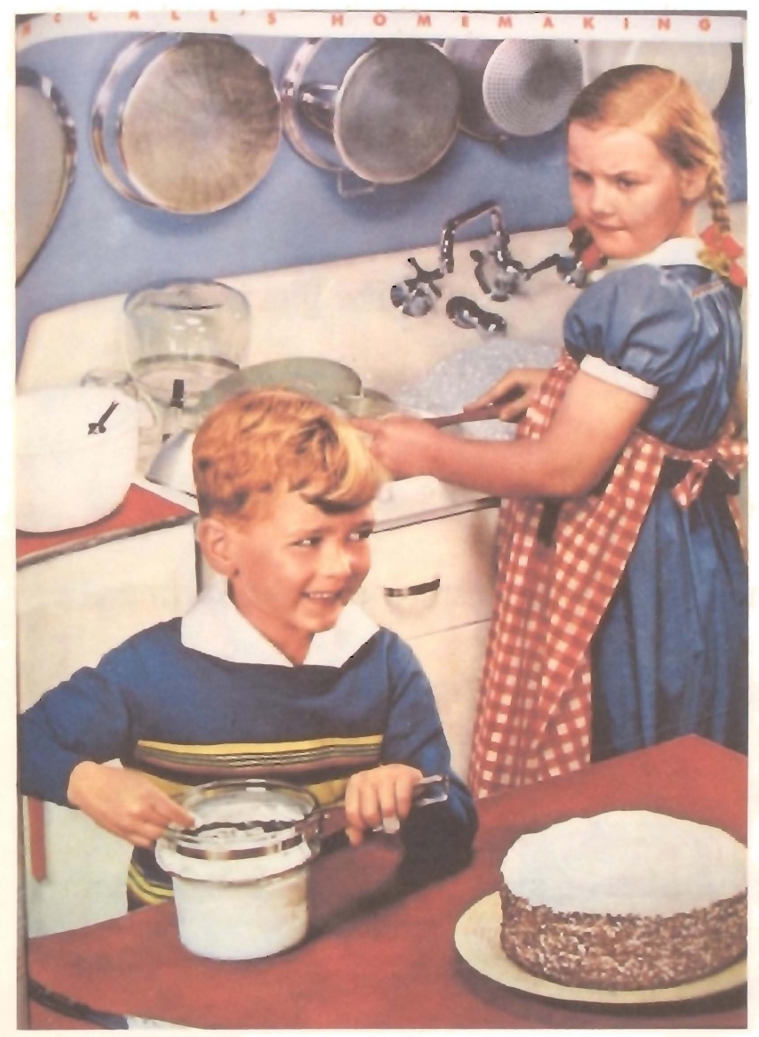

5.1. October 1938
The girl in Muray's image is

participating in women's homemaking

activity. Although during the Depression and

at the beginning of World War II, it was

acceptable for women to work after college

and before marriage, after marriage — and

except in the case of a dire need - women

were expected to abandon their careers and

become mothers and homemakers. ${ }^{5}$ The

United States' participation in the war would

ultimately change that. Domesticity did not

exclude women from the public sphere

entirely yet it limited their economic participation to that of consumers rather than

producers. Particularly during the Depression, the role of the homemaker was more than a mere gender role; it was a status symbol as well. ${ }^{6}$ Being a homemaker implied being married to a successful husband and, perhaps more subtly, having a successful marriage. However, men played a more active role on the domestic front than did the previous generation. ${ }^{7}$ Men were encouraged to engage in parenting and to help with household

\footnotetext{
${ }^{5}$ Jean V. Matthews, "After the Vote," in The Rise of the New Woman: The Women's Movement in America, 1875-1930, The American Way Series (Chicago: Ivan R. Dee, 2003), 179.

${ }^{6}$ Ruth Cowan Schwartz, More Work For Mother: The Ironies of Household Technology from the Open Hearth to the Microwave Oven (New York: Basic Books, 1983), 207 and Jean V. Matthews, The Rise of the New Woman, 179.

${ }^{7}$ The Modernization of Fatherhood: A Social and Political History (Chicago and London: University of Chicago Press, 1997), 118.
} 
maintenance such as doing the dishes. This was nonetheless a secondary role and their primary responsibility remained as breadwinner.

Muray's October 1938 composition reflects women's role during this era by demonstrating both gender roles and familial structure through the filters of cultural standards of the modern American home and family. The children are markers of traditional gender roles and thus the signifiers of true woman ideals. The girl in the image is not performing a new female chore but engaging in one that was passed down from mother to daughter for many generations. While housework has not always been specifically a female task, industrialization further separated the spheres and took men out of the home and into the workplace. Domestic labor had thus redefined itself as being women's work. Perhaps unintentionally, but certainly more subtly, the male domestic role as recipient or consumer of the woman's effort of producing a homemade cake is portrayed in Muray's photograph by the boy stealing the icing on the cake. Had the roles in the image been reversed, with the boy doing the dishes while the girl steals the icing, the image would have had substantially different implications. However traditional the gender roles may appear, it remains within the parameters of modern life. The kitchen is clean and, as evidenced by the hot and cold taps, modern. The mixers and the number of pots and pans hanging in the background suggest both the availability of electricity in the home and the use of electrical appliances.

By the late Depression when this image was published, the task of homemaking had changed in comparison with the previous era. This was largely due to the growing availability of what are now considered basic amenities such as electricity, plumbing and 
central heating. ${ }^{8}$ This resulted in the subsequent production of a growing number of appliances such as the washing machine, refrigerator and vacuum cleaner, which would "revolutionize" housework. ${ }^{9}$ Although numbers conflict, it is estimated that by midDepression most urban dwellers had standard utilities. ${ }^{10}$ That said, the greater part of McCall's readership was found in small towns scattered throughout the United States; the more remote and less densely populated the area, the more time it took for standard utilities to become available.

Unfortunately, in spite of all their promise, these modern conveniences did not reduce the amount of work that needed to be done. As historian Ruth Cowan argues in More Work for Mother: the Ironies of Household Technologies from the Open Hearth to the Microwave Oven, the automation of housework did not actually decrease the number of hours women spent doing housework. " Rather, it raised the bar for the amount of housework that needed to be done. ${ }^{12}$ For instance, the amount of time required to wash a load of laundry decreased yet the frequency of washings as well as the amount of clothing increased, a phenomenon largely encouraged in advertisements by the soap industries that were perhaps struggling during the Depression. Moreover, while the vacuum cleaner removed the tedious task of beating the rugs during the yearly springcleaning, it increased the amount of weekly maintenance. With the increased

\footnotetext{
${ }^{8}$ Ruth Cowan Schwartz, More Work For Mother, 174.

${ }^{9}$ Ruth Cowan Schwartz, More Work For Mother, 174, and Susan Strausser, Never Done, 264.

${ }^{10}$ Susan Strausser, Never Done, 263.

"In this chapter, Schwartz makes the distinction in homemaking between those who were living comfortably and those who were struggling to make ends meet at a time when living standards were rising. Interestingly, she finds that economically comfortable homemakers' housework hours increased much more than economically struggling ones because increased automation coincided with a decrease in hired help. Ruth Cowan Schwartz, "Household Technology and Household Work: Between the Wars," in More Work For Mother, 172-191, and specifically on the number of hours women spend doing housework see Ruth Cowan Schwartz, More Work For Mother, 178

${ }^{12}$ Ruth Cowan Schwartz, More Work For Mother, 188.
} 
responsibilities associated with consumerism and parenting, the end result was that women spent the same number of hours doing housework as their mothers did. ${ }^{13}$ Cowan argues that the number of hours women spent as homemakers surpassed the number of hours a husband spent at his full-time job. ${ }^{14}$ It is therefore understandable that a task as monumental as homemaking would be difficult to abandon for extra income, if the woman chose to work outside the home. ${ }^{15}$

However traditional the female gender role in Muray's image may have appeared on its own, within the magazine context it was much more embedded in consumer culture. In the subsequent pages, there are nine articles on homemaking printed alongside an astounding fifty-eight advertisements specifically aimed at the housewife, featuring items such as canned goods, cleaning products, and bathroom tissue. Furthermore, four of the nine homemaking articles include advice on consumerism such as tips on how to buy canned food and furniture. The remaining articles feature recipes, cooking tips, and one parenting advice article (which, incidentally, advocates making your children work for extra allowance money). As a whole, it resonates with consumer culture and reinforces the importance of women's economic activity thereby validating the role of the consumer and concomitantly maintaining traditional family values.

Two other examples of Muray's "Homemaking" covers for McCall's that are reminiscent of traditional woman ideals include the covers for July 1937 and January 1942. On the July 1937 cover, a child is pushing a child-size wheelbarrow full of fresh garden vegetables. The cart contains an eggplant, yellow squash, tomatoes, cherry tomatoes, beet greens, and a variety of other greens. The child is clothed in jean denim

\footnotetext{
${ }^{13}$ Ibid., 178.

14 Ibid., 199.

${ }^{15}$ Ibid.
} 
overalls and a striped shirt. The background for the image is a multitude of flowers in bloom in front of a wooden fence. Like the previous image, this positions the home as still being productive even in 1930s culture. Here the child is pushing a variety of fresh garden vegetables during the era when supermarkets were an established venue for

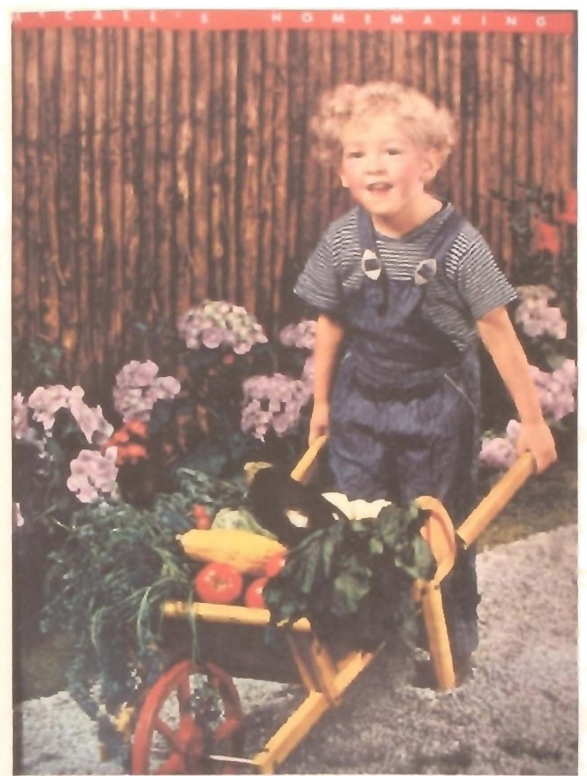

5.2. July 1937

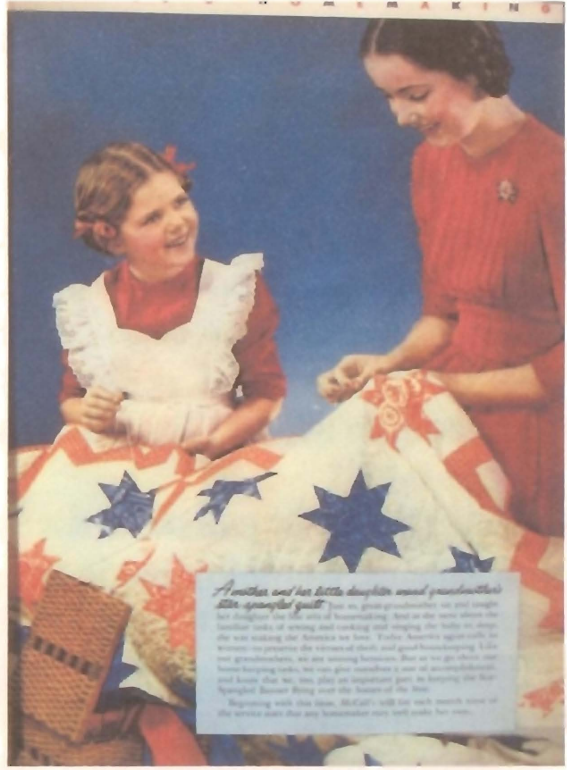

5.3. January 1942

feeding the family. ${ }^{16}$ Women's role had included the practice of buying food since the last quarter of the nineteenth century. ${ }^{17}$ This fact alone greatly contributed to establishing women as primary consumers as well as giving them a specific and participatory role in the public sphere. Modern living remains evident in Muray's image, even if more subtle, and can be seen in what appears to be a fenced-in backyard decorated with flowers.

In Muray's second social tableau, the January 1942 cover depicts a mother and daughter sewing a star-spangled quilt. The colours in the image are red, white and blue. In this image, homemaking is not only romanticized but it is also a patriotic activity. Here, a girl is learning the craft of quilting from her mother, something that has been

\footnotetext{
${ }^{16}$ Ruth Cowan Schwartz, More Work For Mother, 179, and Susan Strausser, Never Done, 259.

${ }^{17}$ Susan Strausser, Never Done, 244.
} 
considered a specifically female activity for many generations. The text in the image adds even more connection to the past by letting the reader know that this was a grandmother's quilt and was passed down just as the art of homemaking has been passed down from generation to generation. The text reads:

A mother and her little daughter mend grandmother's star-spangled quilt. Just so, great-grandmother sat and taught her daughter the fine arts of homemaking. And as she went about the familiar tasks of sewing and cooking and singing the baby to sleep, she was making the America we love. Today America again calls its women-to preserve the virtues of thrift and good housekeeping. Like our grandmothers, we are unsung heroines. But as we go about our home-keeping tasks, we can give ourselves a star of accomplishment, and know that we, too, play an important part in keeping the Star Spangled Banner flying over the homes of the free. ${ }^{18}$

These two images, so traditional in intent, were embedded in a McCall's magazine context filled with advertisements and advice for the consuming homemaker.

However, not all of Muray's "Homemaking" covers reflected traditional values to that extent. Although more infrequent, some of Muray's images completely acknowledge

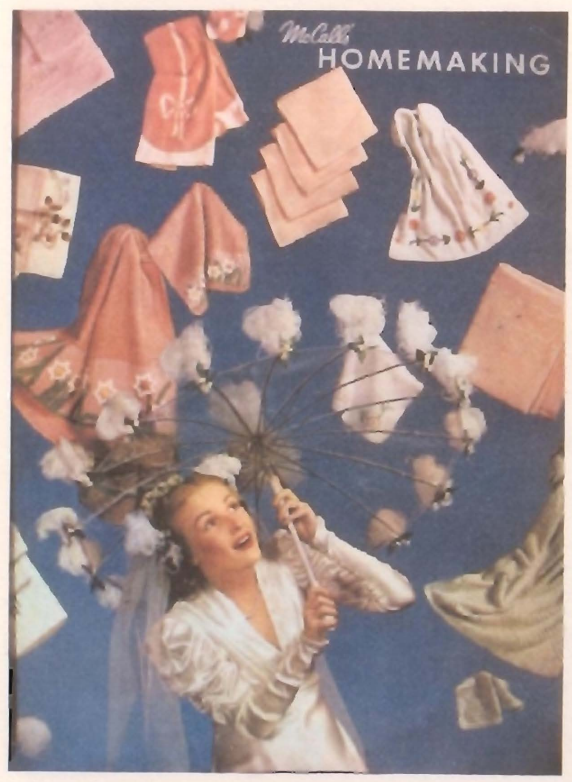
consumer culture. One example is McCall's

"Homemaking" cover for February 1939. This image is a visual pun of a wedding shower. In the image, a bride shields herself with an umbrella from a barrage of falling objects, which are part of her trousseau such as linens, towels and face cloths. These items were some of a large number of consumer products whose uses were part of a homemaker's daily life.

5.4. February 1939

\footnotetext{
${ }^{18}$ Mc Call's, "Homemaking," January 1942.
} 
Perhaps most telling of Muray's images for McCall's "Homemaking" covers when they enter the magazine context is the connection between homemaking and consumption. ${ }^{19}$ More frequently than not, the traditional woman values were maintained in Muray's editorial tableaux, even if photographed in a modern world. However, once Muray's images are placed in the context of the magazine and are displayed amongst a multitude of product advertisements and consumer goods targeted specifically at the homemaker and supported by articles and advice from writers and editors, the connection between homemaker and consumer cannot be understated. This dichotomy is not conflicting but in fact reflects the co-existence and diversity of gender roles, as well as their evolution. The modern woman accepts her position as economic consumer within the family structure as well as the more traditional role of housekeeper. She maintains traditional family values under the new auspices of wholesomeness while participating in modern life and consumer culture.

\footnotetext{
${ }^{19}$ For an examination of the connection of housekeeping and consumerism up to the 1930s see Jennifer Scanlon, Inarticulate Longings, 73.
} 


\section{Motherhood and American Families}

Nickolas Muray's photographs commissioned by McCall's magazine offered a limited view of the American family. While remaining within the parameters of cultural expectations, his images were perhaps as inclusive as they were exclusive. In his images, mothers were confident and educated women who, through positive familial activity, contributed to the emotional nourishment and well being of child, and family, and thus to society. Yet the women depicted during the Depression and much of World War II were also limited to white middle class homemakers. Mothers as depicted by Muray for McCall's were modern in their domestic and parenting activity all the while preserving the traditional family ideal that a woman's place was in the home.

Muray's editorial carbro photograph published as the cover for the January 1940 issue of McCall's features a woman reading to a child from a book titled The Night Before Christmas. In the image, the child appears comfortably seated on her mother's lap. The colour scheme for the image is red, white and blue. The mother's clothing is blue, as is the backdrop and child's hair ribbon; the child is in white, and the book, lipstick and painted nails are red. As stated earlier, while Muray's front cover typically depicted a. 
woman who could be of any age or marital status, it was nonetheless normal for issues near holidays to have a mother and daughter, just as it was common for a spring or summer issue to feature a bride. When comparing the pre to post published versions of the January 1940 image, the original carbro reveals that the eyelashes were darkened and defined and that the image was heavily cropped for publication. The crop creates a more intimate portrait of the mother and child. In addition, and as can be expected, the colours on Muray's pre-publication print are much cooler and significantly more vibrant than the published version. And there is much more detail in the shadow areas of the print.

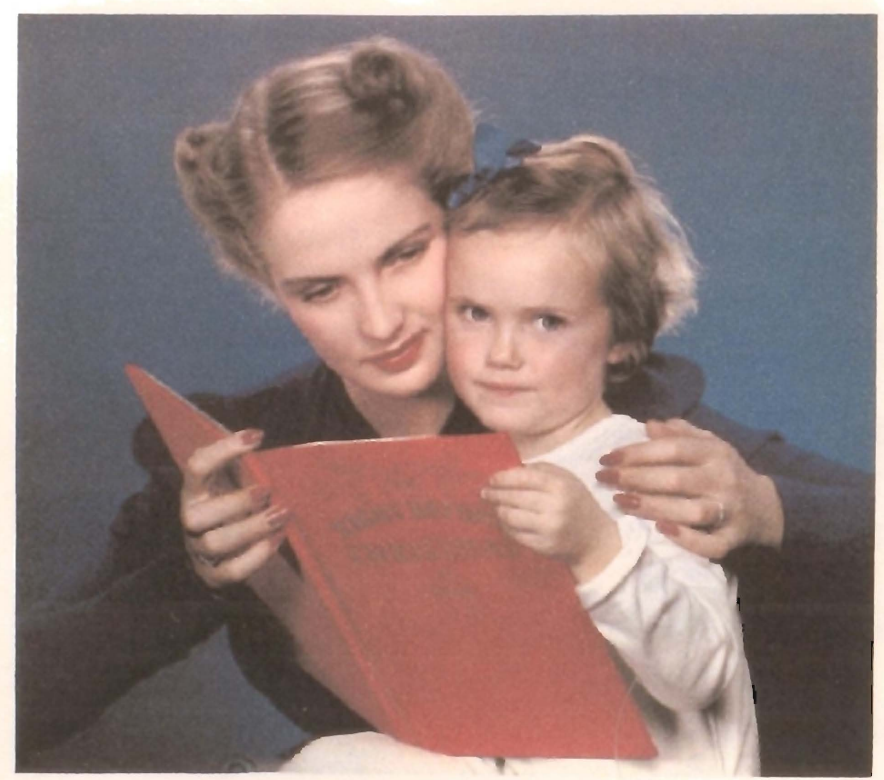

6.1. [frontispiece] January 1940 Courtesy of George Eastman House

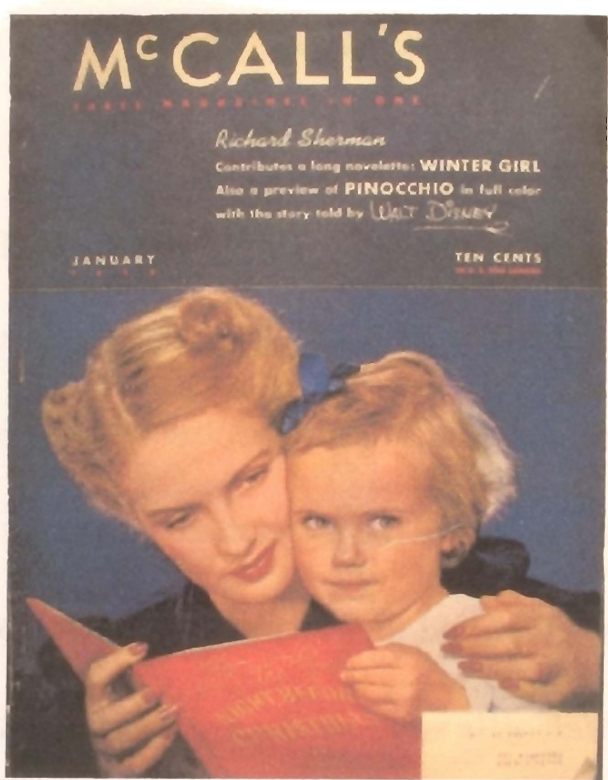

6.2. [frontispiece] January 1940

In the published version, above the photograph are the words that state: “MCCALL'S: THREE MAGAZINES IN ONE," "Richard Sherman contributes a long novelette: WINTER GIRL." And, "Also a preview of PINOCCHIO in full colour with the story by Walt Disney." The magazine costs ten cents, the same price as its leading competitor, Ladies' Home Journal. The two inside covers of the magazine were not photographed by Muray. The "Homemaking" cover features a boy and a girl pulling taffy 
and the "Style and Beauty" cover is that of an elegant woman dressed in rose-coloured clothing reclining gracefully on a daybed. The novelette advertised on the front cover titled Winter Girl is the story of a small town working girl who loved and lost her lover to her college-educated and city-smart best friend when the latter returned home during summer vacation.

In the social tableau, the two models are playing the roles of mother and daughter reading bedtime stories. Visual information in the image includes the wedding ring worn by the mother, the manner in which she holds the child in close proximity and the child's dress, which appears to be a nightgown. The child looks healthy and happy. This mother is enjoying a quiet moment with her daughter and participating in modern activities of literate motherhood. As the depiction implies, she was educated enough to read and was informed about the importance of reading to her children. As parenting advice of the time advocated through articles and depictions such as this one, reading to your child fostered a parent-child bond that contributed to the child's healthy emotional development, and perhaps more subtly, provided a necessary tool for becoming a well-adjusted adult. Muray's photograph embodied the magazine's perceptions of motherhood responsibilities and displayed the results of modern research regarding responsible parenting by virtue of this healthy and adoring child.

Reading to your child was a parenting responsibility that had only recently become standard practice. Victorian mothers read their children if they had servants to do the housework, but in no way could a mother who spent two full days doing the laundry, tended to the hearth and carried in all of the water used by the family have had much time 
or energy to read to her child.' As physical housework decreased due to automation and education was offered outside the home, emotional nourishment and motherhood tasks increased. ${ }^{2}$ A mother in the 1930 s would have been doing a number of tasks unknown to her mother, tasks such as driving her children to doctors' appointments, parties and music lessons, and supervising children at the playground. ${ }^{3}$ In addition, a mother would have been expected to keep informed about modern parenting practices. This included reading about parenting in her spare time in magazines such as McCall's and talking to her husband about what she had read. ${ }^{4}$ Motherhood in the thirties was a clear and definable task separate from housework and shopping. It contributed to the emotional health and well being of the family. ${ }^{5}$

Another of Muray's photographs of mother and daughter engaging in domestic activity can be seen in September 1940s "Style and Beauty" original and published versions of the photographs. This editorial image finds the woman and child packing a trunk to go on holiday. In the scene, the daughter observes her mother as she arranges a white floor length evening gown on a hanger. The mother is seated and surrounded by objects. Amidst the array of items arranged by the photographer, one can see a tennis racket, riding boots and portraits of the wife and husband. Aside from the portraits, which primarily serve to include the husband in the image, the items suggest an economically

\footnotetext{
${ }^{1}$ On following published-parenting advice before the automation of housework see Susan Strausser, Never Done: A History of American Housework (New York: Henry Holt, 2002), 241.

${ }^{2}$ Susan Strausser, Never Done, 241.

${ }^{3}$ Ruth Cowan Schwartz, More Work For Mother: The Ironies of Household Technology from the Open Hearth to the Microwave Oven (New York: Basic Books, 1983), 179.

${ }^{4}$ Ralphe LaRossa, "Fatherhood in the Popular Press," in The Modernization of Fatherhood: A Social and Political History (Chicago and London: University of Chicago Press, 1997), 118.

${ }^{5}$ Similarly, homemaking, which was becoming increasingly devalued, came to be defined not as real and productive work but as a labor of love that contributed to the emotional well-being of the family as well. Stephanie Coontz, Marriage, A History: From Obedience to Intimacy or How Love Conquered Marriage (New York: Viking, 2005), 155 and Ruth Cowan Schwartz, More Work For Mother, 179.
} 
thriving household. Leisure activities such as horseback riding and tennis were associated with the activities of the well to do. A sticker on the trunk reveals that this woman is

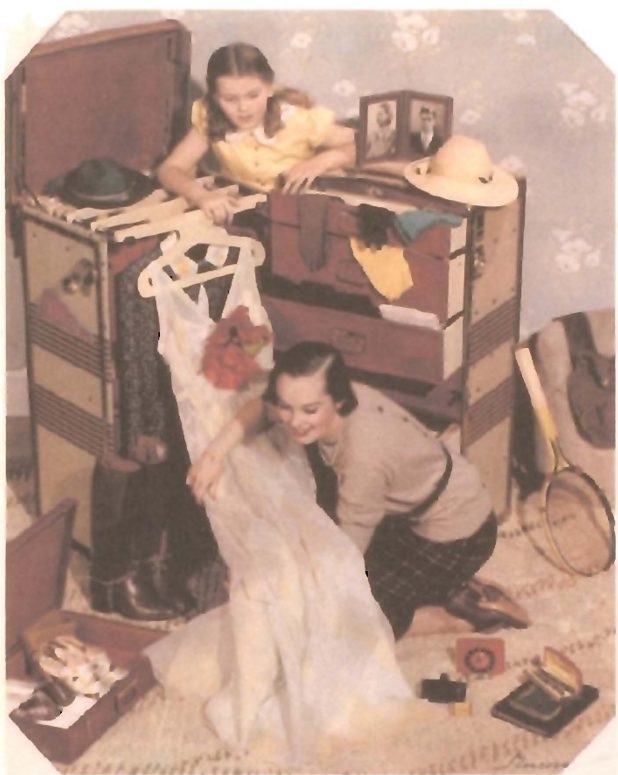

6.3. "Style and Beauty," September 1940 Courtesy of George Eastman House

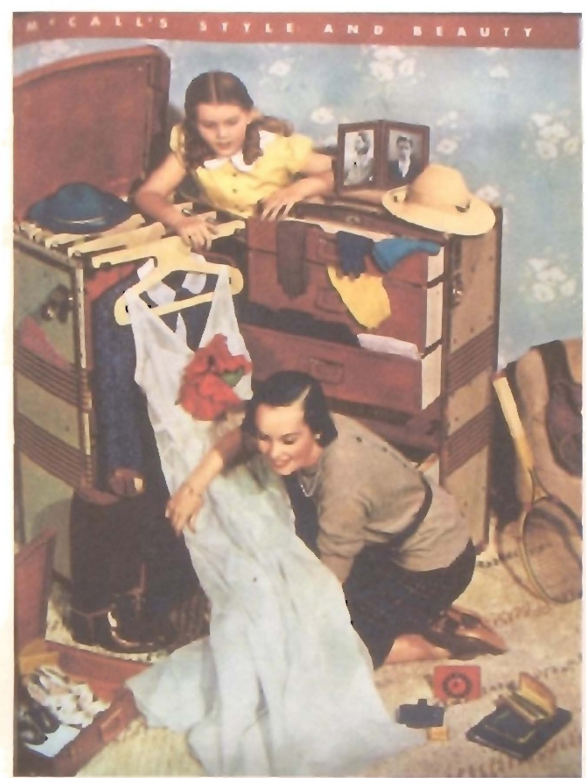

6.4. "Style and Beauty," September 1940

educated and received her post-secondary education at Vassar College for women. When comparing the pre and post published versions of this image, there is very little change in terms of cropping. However, there is quite a shift in color, and this carbro is much warmer in tone.

Muray's November 1939 "Homemaking" cover photograph for McCall's depicts an American family unit in a very wholesome scene. In the image, a family of four, composed of a mother, father, boy and girl, enter a grandmother's kitchen for a holiday meal. On the table are two pies, fresh fruit and a basket of baked goods. When comparing the Muray's carbro image to magazine reproduction, the image crops tightly around the family members, which gives the illusion of intimacy. The grandmother is mixing something in a bowl. Depression families were smaller in size than in previous generations for numerous reasons including economic constraints, marriage 
postponements due to women's education and entry into the workforce, and the availability of information and products on birth control. ${ }^{6}$ By 1940 , urban white married couples had an average of two children per family while rural and non-white families had more. ${ }^{7}$ Yet, the children that were born stood a much better chance of survival due to increased living standards and the availability of health care. These two factors

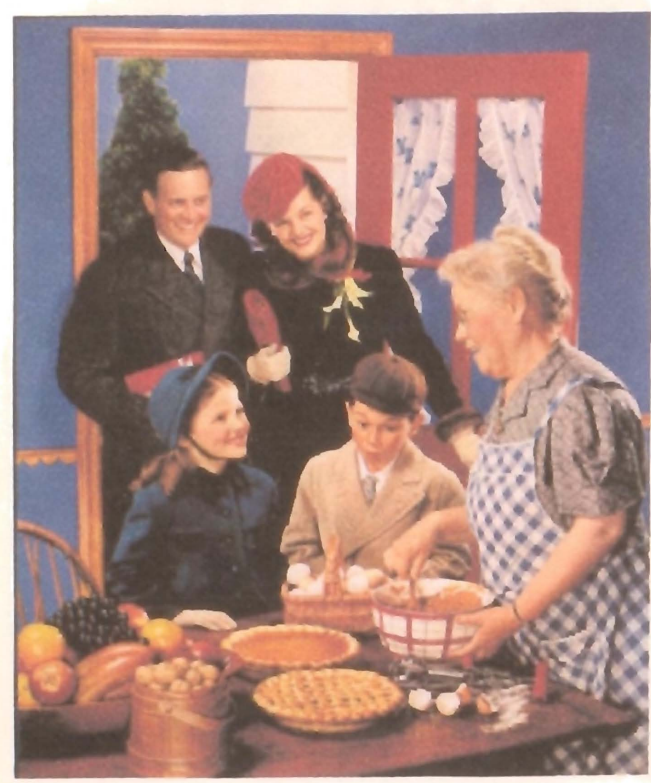

6.5. "Homemaking" November 1939 Courtesy of George Eastman House

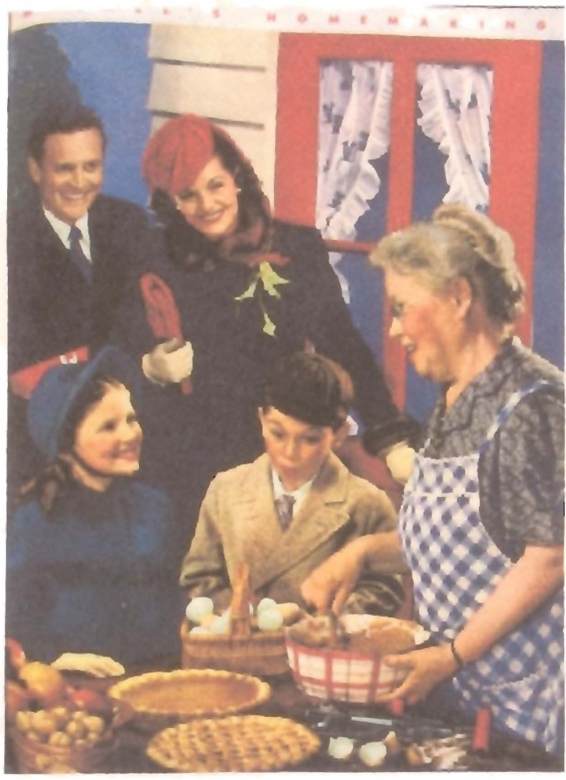

6.6. "Homemaking," November 1939

contributed significantly to a drop in the very high infant mortality rate in America. ${ }^{8}$ This made the existing children all the more important.

Another common trend, though not reflected in $M c$ Call's, was the decision couples made to put off marriage ${ }^{9}$ and children. ${ }^{10}$ Some couples did delay having children

\footnotetext{
${ }^{6}$ S. J. Kleinberg, Women in the United States: 1830-1945, (New Brunswick, New Jersey: Rutgers University Press, 1999), 234.

${ }^{7}$ S. J. Kleinberg, Women in the United States: 1830-1945, 234.

${ }^{8}$ The United States infant mortality rate was 10 percent in 1915 (one of the highest in the Western World) and 5.6 percent in 1935, a near half drop despite the Depression. Adapted from Historical Statistics of the United States, From Colonial Times to 1957 (Washington, 1960), series B 107, 25, seen in Ruth Cowan Schwartz, More Work for Mother, 179.

${ }^{9}$ Stephanie Coontz, Marriage, A History, 220.

${ }^{10} \mathrm{~S}$. J. Kleinberg, Women in the United States: 1830-1945, 234.
} 
due to economic constraints while others chose not to have them for greater economic freedom, something that would likely be forfeited once a child was born. ${ }^{11}$ In addition, there were growing numbers of families during the Depression headed by only the mother. ${ }^{12}$ Within two parent familial structures, factors such as the reduction of employment work hours and the isolation of suburbanization affected the family unit as it became more introverted. As a result, the father played an increasing role in childrearing, though still secondary to the mother's. ${ }^{13}$ Parenting advice advocated that men contribute to their children's emotional development, sometimes portraying men as teachers and other times as buddies to their children. ${ }^{14}$

Taking a closer look at all of Muray's photographs in McCall's, which can be seen in appendix B, one observes that the majority of the portraits are images of white middle class women, followed by portraits of children and finally, portraits of couples. From the one hundred and sixty-two known cover photographs by Muray for McCall's, sixty-six are portraits of one woman, and another eleven are pictures of two or more women. Of the thirty-two photographs that include children, seven are mothers and daughters, and another five are of only girls. Nine are of boys and five are one boy and one girl. Two are of infants and two more are family portraits. One photograph is of a flower girl and bride, while the remaining photograph is of a grandfather and grandson. There are no pictures of mothers or fathers and sons. Out of the thirteen photographs of

\footnotetext{
${ }^{11}$ Ibid.

${ }^{12}$ On the demasculinizing effects of women-headed households see Stephanie Coontz, Marriage, $A$ History, 219. On death or departure of the father see Karen Anderson, Changing Woman: A History of Racial Ethnic women in Modern America (New York and Oxford: Oxford University Press, 1996), 110.

${ }^{13}$ Ralphe LaRossa, "Fathcrhood in the Popular Press," in The Modernization of Fatherhood, 118.

${ }^{14}$ Even though womens' and parenting magazines had primarily a female audience, fathers were the recipients of parenting advice from popular magazines, whether directly or indirectly, because their wives may have discussed what they had read or modeled behavior recommended in parenting articles, Ralphe LaRossa, The Modernization of Fatherhood, 118.
} 
couples, the woman is the key element in the composition and the man is more of an appendage or decoration that completes the picture. The four remaining pictures of people do not fall into the categories described above. ${ }^{15}$ Of the remaining thirty-six pictures, eighteen are of foods, eleven are still lives, three are of pets and two are montages. Two photographs are of unknown subject matter. ${ }^{16}$

Muray's images in McCall's presented a picture of the American family based on popular ideology and cultural expectations. His photographs of white middle class women and children clearly did not represent the diversity of American families. However, from the perspective of the magazine, they evoked popular sentiment. Mothers during the Depression were limited to the domestic sphere in photographs, even if amidst a variety of consumer products. Yet even though their roles as mothers remained traditional, the act of parenting included modern parenting practices and ideologies. Muray's mothers read to their children and played with their children. Muray's children played dress-up, made puzzles and decorated Easter eggs. Muray's families as commissioned by McCall's were small and emotionally well nourished by their stay-athome mothers. For the duration of the United States' involvement in World War II, Muray continued to portray mothers for McCall's as homemakers but the context diversified the meaning of the images by including women in the workforce. During this time, most images of mothers and children remained similar in subject matter-albeit increasingly patriotic- but articles evolved to include advice on childrearing for working mothers.

\footnotetext{
${ }^{15}$ One photograph is of a woman and two soldiers, one is of two soldiers, and the last two are the split pictures by Muray and his partner Ruzzi Green, which feature portraits of women on half the page and portraits of soldiers on the other half. The latter two will be discussed in Chapter 8 and can be seen in figures 8.4 and 8.5 .

${ }^{16}$ Two images are missing.
} 


\section{Mixed Visions of "Style and Beauty"}

Nickolas Muray's editorial photographs for the "Style and Beauty" section of McCall's were diverse in their subject matter and composition. Frequently, women in these images were part of the younger readership demographic and often appeared as unmarried or as brides. Like the "Homemaking" covers, many of Muray's "Style and Beauty" photographs were social tableaux. They were visual depictions that told a story. However, once placed in the magazine, the images were altered by their contexts.

Muray's carbro print reproduced for August 1940's "Style and Beauty" section cover for McCall's is an editorial tableau of a woman having her fortune read. In the image, the fortuneteller holds the woman's right hand while she points to lines on her upturned palm. Beneath their hands, tarot cards lie scattered on the table. The woman whose palms are being read has a facial expression fashioned in such a way that she seems to be pronouncing the sound "ooooh," perhaps in acknowledgment of new and interesting information. She wears a charm bracelet on her left arm and has painted nails. Her fair hair is styled à la mode, as is her make-up. She wears a yellow shirt with white trim. The fortuneteller wears a green shawl and is adorned in gold bracelets, earrings and 


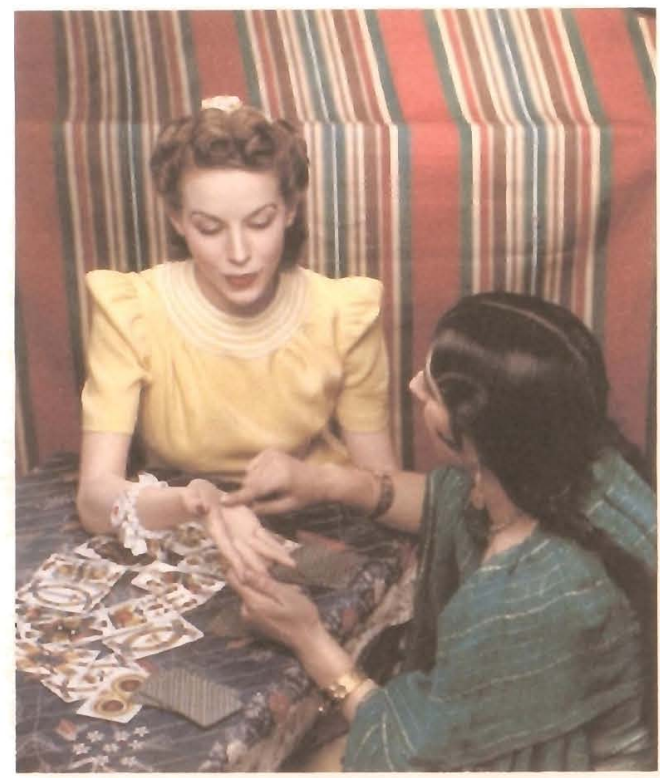

7.1. "Style and Beauty," August 1940 Courtesy of George Eastman House

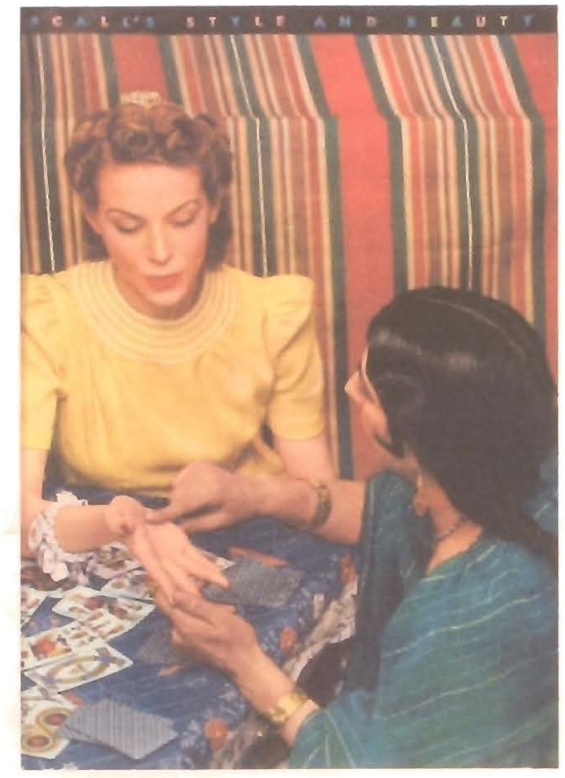

7.2. "Style and Beauty," August 1940

a necklace. Her black hair is styled in two long braids. Her face is indiscernible. Peering closely at the photograph, one can see the image has been slightly touched up. Both women's eyelashes were darkened and defined. The published version is warmer in tone, less vibrant in color and is cropped tightly around the two women.

When printed in $\mathrm{McC}$ all's, the image preceded an article by Hildegard Fillmore, a long time "Style and Beauty" columnist for McCall's. In her article entitled "Let Me Tell You Your Fortune," Fillmore presented the viewer with four tarot cards, each of which contains mildly related beauty advice. ' The first card, entitled "You're Going on a Journey," tells readers what clothing material packs best and advises against the threat of offending others (with body odor) while traveling. The second card entitled "I See a Man in your Life" describes the necessity of having a well-organized handbag since a tidy purse represents a tidy woman. This is important should a new male acquaintance happen to see its content. The third card, "Beware of Unknown Foes," is a metaphor of the

\footnotetext{
'Hildegard Fillmore, "Let Me Tell You Your Fortune," McCall's, August 1940, 83.
} 
potential social harm caused by visible body hair. The last card titled "You Will Have a Happy Future," neatly wraps up the fortune "predictions" by assuring the reader that with proper efforts in skin care and personal relaxation, she too can have luck and love. In each section, there was a description of what types of products were available to remedy each potentially harmful situation. For instance, the third card described methods of hair removal available such as shavers, depilatory creams and electric shavers. Even though product types were recommended, no specific brands were endorsed.

Alone, Muray's photograph of a woman having her fortune told is an interesting social tableau depicting an experience that the average woman of 1940 could understand. Visually, the diagonal lines and contrasting colours make this a compelling and aesthetically correct composition. As well, the downward angle taken by the photographer for the shot, the woman's facial expression and the air of mystery implied in cards create an element of intrigue, as though the viewer was a fly on the wall about to discover a secret. While she portrays what was considered fashionable and beautiful, this is not the subject of the photograph. However, paired with the article, the fortune becomes the structure for a set of guidelines that turn the meaning of the image into a "body project," ${ }^{2}$ for the reader. "Body projects," as described by Joan Jackobs Brumberg, involve control over one's body to coincide with societal expectations. In 1930s and 1940 s women's magazine advice this typically implied increased consumption. ${ }^{3}$ In this image, the secret revealed was beauty advice. Following the suggestions made by Fillmore, the woman in Muray's image becomes the recipient of beauty advice, which is

\footnotetext{
${ }^{2}$ Cleverly titled "the body project," Joan Jackobs Brumberg describes the changes in control over the body for girls and women from the Victorian era onwards. Joan Jackobs Brumberg, The Body Project: An Intimate History of American Girls (New York: Random House, 1997).

${ }^{3}$ On "body projects" perpetuated by magazine content see Joan Jackobs Brumberg, The Body Project, 70.
} 
positioned as a deciding factor on whether one will be successful in love and life. The "body project" in this circumstance involves control over one's appearance and smell by proper use of commercial beauty and hygiene products. This pair of images, like many of Muray's images, gains its consumer meaning not by its inherent content but by the context in which it is placed.

Photography played an important role in developing what cultural theorist Naomi Wolf has termed the beauty index, a cultural ideal of physical beauty. Wolf contends that beauty as we have come to understand it is a relatively new idea, dating back to no earlier than $1830 .{ }^{4}$ Previous to the development of photography and other means of technological reproduction, women had limited exposure to external images of beauty. However, with the advent of new technologies that allowed for the mass production and dissemination of images, photographic objects such as daguerreotypes, cabinet cards and fashion plates reproduced in mass publications propelled the creation of the beauty index. ${ }^{5}$ Some disagree with the extent to which Wolf positions beauty as a societal construct, believing instead that human evolution, biology and sexual selection play a greater role in deciding what is attractive. ${ }^{6}$ Nevertheless, Wolf makes a strong argument for beauty's entrance as part of collective consciousness, an entrance perpetuated and sustained by mass media imagery.

In the pages of $M c C a l l ' s$, the possession of beauty was often synonymous with finding love. One such example is Muray's November 1943 "Style and Beauty" section cover. The image features a pretty young woman and her sweetheart pulling at a

\footnotetext{
${ }^{4}$ Naomi Wolf, The Beauty Myth: How Images of Beauty Are Used Against Women (New York: W. Morrow, 1991), 15.

${ }^{5}$ Ibid.

${ }^{6}$ Nancy Etcoff, Survival of the Prettiest: The Science of Beauty (New York: Anchor Books, 1999).
} 
wishbone while gazing into each other's eyes. The woman is perhaps in her early twenties, as revealed in her youthful face and hairstyle. She is representative of the younger portion of the readership, a common feature in Muray's "Style and Beauty" covers. The man is a soldier, as were nearly all of Muray's male subjects during the war. Both bear emblems confirming wartime participation on their attire. While the young woman in the image is noticeably pretty, there is no overt declaration in the image itself confirming that it is her good looks that won her the attention of a handsome soldier. However, placed under the heading of "Style and Beauty" and within the context of the magazine, an alternative meaning is revealed. Muray's cover image of a pretty young woman pulling a wishbone with her sweetheart soldier introduced a multitude of articles and advertisements revealing the message that with proper attention to appearance and scent, one would find true love. Moreover, proper attention usually involved proper consumption. In advertisements particularly, slogans were written and illnesses created that directly used love to sell. Some examples include the unforgettable slogan "Always a bridesmaid, never a bride," and the socially ostracizing "illnesses" of halitosis (bad breath), ptosis (skin bulges sagging over corsets) and pink toothbrush.

No "Style and Beauty" section would be complete without a reference to fashion. Having been a vehicle for fashion from the beginning, the "Style and Beauty" section continued to include a fashion section throughout the Depression and World War II, even if the McCall's patterns were relegated to the last ten or so pages of the magazine. The patterns illustrated were printed with advice on how to wear them, as can be seen in the November 1938 eveningwear illustrations. Curiously, while Muray's models always appeared in style, they seldom wore clothing advertised in the pattern pages. Rather, their 
mode of dress embodied the style of the times and patterns with similar aesthetics were depicted. In the "Style and Beauty" photograph of that issue, Muray's very elegant model

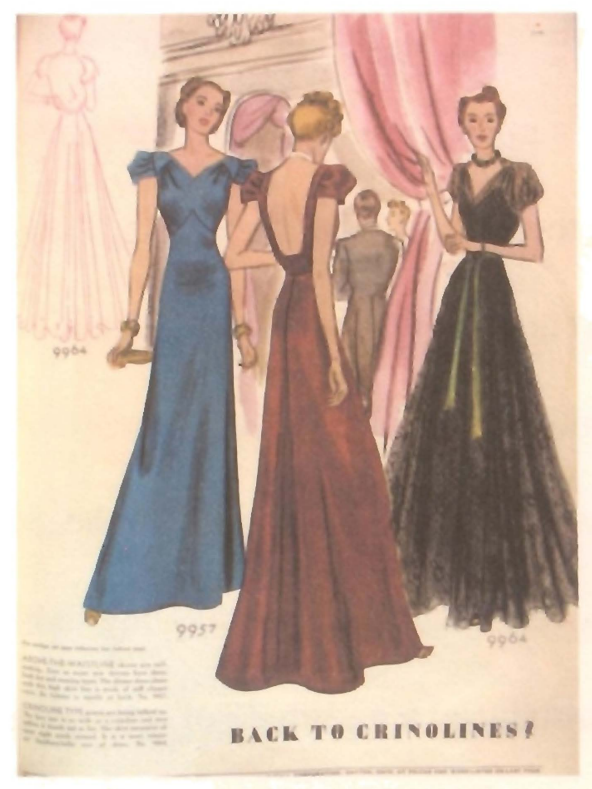

7.3. [McCall's Pattern Illustrations] November 1938

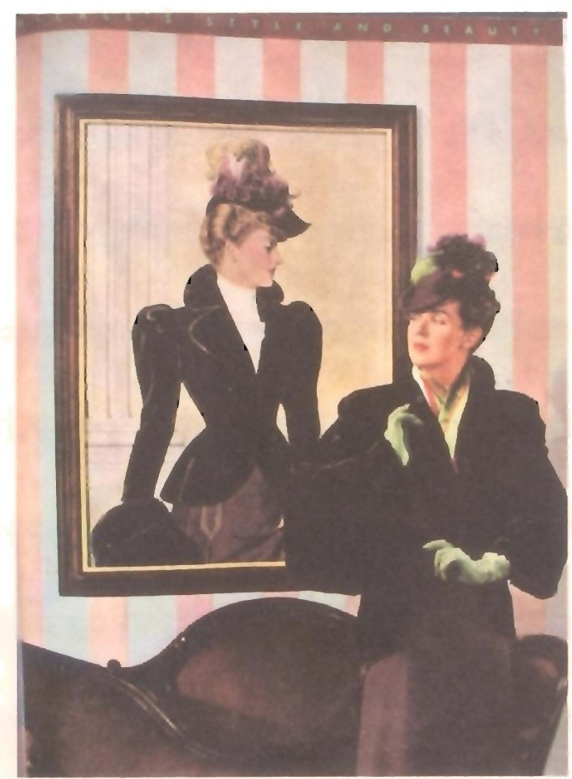

7.4. "Style and Beauty," November 1938

is glancing at a painting of a similarly dressed woman. It is important to note that

Muray's images were not usually strictly about fashion but were most often a social tableau of sorts, as was this image.

Though not the majority, some of Muray's images were indeed strictly about fashion in consumer culture, such as the "Style and Beauty" covers for April 1938 and April 1939. In both of these photographs, the subject is a stylish shoe. Unlike the other scenarios described, these images related quite directly to consumer culture even without magazine context. Fashion was particularly pivotal in consumer culture because it blurred some class lines and rendered objects useless before their practical lives were over. ${ }^{7}$

\footnotetext{
${ }^{7}$ Manufactured clothing and the availability of textiles blur class lines by making clothing similar in style amongst the working and middle classes, yet this excludes the very rich and very poor. On making items obsolete see, Thomas Hine, I Want That: How We All Became Shoppers (New York: HarperCollins, 2002), 98.
} 


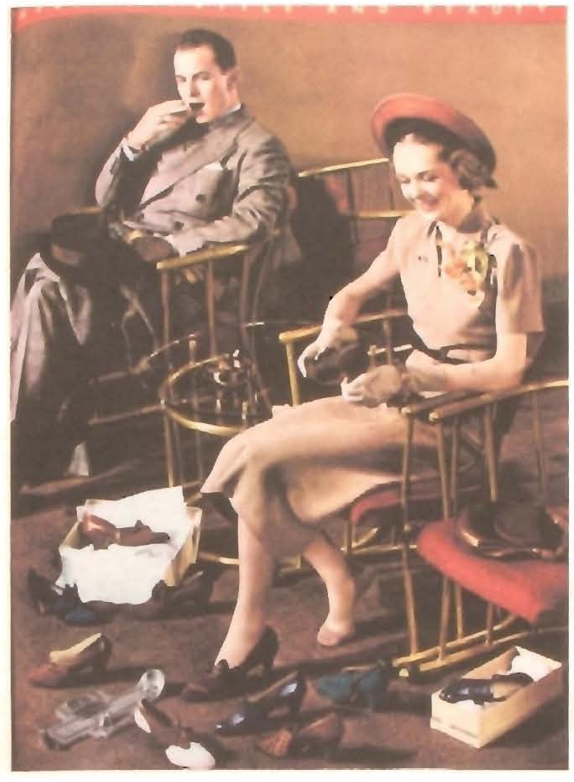

7.5. "Style and Beauty, April 1938

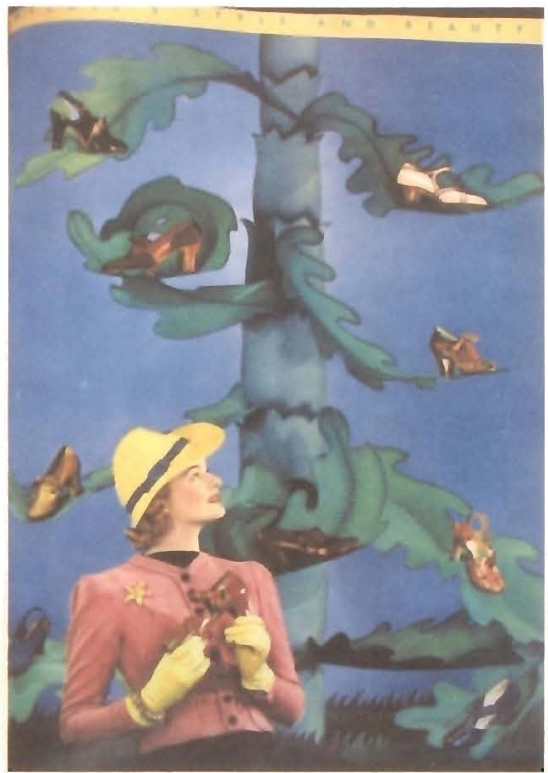

7.6. "Style and Beauty," April 1939

Muray's editorial images for the "Style and Beauty" section of the magazine were similar to those created for the "Homemaking" covers because they were images that told a story. Their consumer meaning amplified once the images were printed in the context of the magazine. The social tableaux created may have used predetermined notions of beauty in their choice of models, but the situations were not necessarily related to the acquisition of beauty. Rather, they usually depicted the enjoyment of life and love. Alone, the images presented an intriguing situation. Within context, they were a commercial conduit that used beauty and the body to situate articles and position products that promised love and social success. 


\section{Working Women}

During World War II, the greater part of Nickolas Muray's images for McCall's remained similar in subject matter to the Depression era imagery, but a significant diversification occurred. For the first time, they included women's participation in the economic sphere as producers instead of consumers. These images depicted working women performing tasks related to the war effort. The content of the magazine also diversified to include paid work as part of women's role. Furthermore, the government used the magazine as an outlet to keep the population informed about the country's need. ${ }^{1}$ Articles on consuming promoted rationing rather than purchasing. Even fashion changed and simplified. Temporarily, women were visually represented as economically productive members of society in Muray's images for McCall's.

Muray's cover of the September 1942 issue of McCall's features a woman operating heavy machinery. Like other McCall's cover women, she is pretty, clean and well made up. Additionally, her age is nondescript. In this image, the absence of a wedding ring is an accurate description of a machine operator rather than an indicator of

\footnotetext{
'Mary Ellen Zuckerman, A History of Popular Women's Magazines in the United States, 1792-1995 (New York and Oxford: Oxford University Press, 1991), 194.
} 
marital status. What is distinctly different between this image and Muray's typical cover images is that this woman in her yellow shirt and red cap is not simply smiling for the

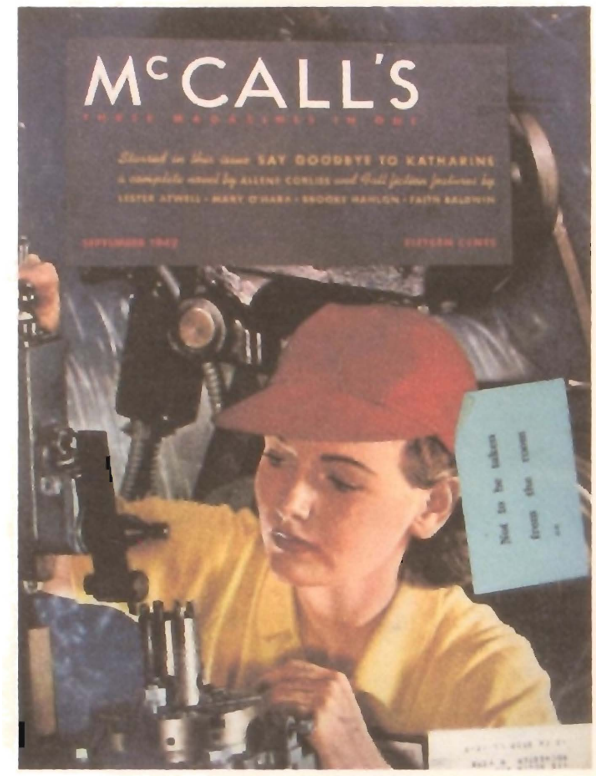

8.1. [frontispiece] September 1942 camera, she is working outside the home. She is now an economically productive member of society.

Furthermore, she is participating in an occupation that previously excluded women. In the past, women's employment opportunities were quite different from men's occupations. Women most often held positions in the white and pink-collar industries, such as nurses, secretaries, telephone operators, schoolteachers, hairdressers, and seamstresses. ${ }^{2}$ The United States' entrance into World War II resulted in a shortage of men on the home front available for the increased production needs for the war effort. Thus, women were encouraged by images such as this to join the workforce in areas such as construction and manufacturing.

To accommodate the changing times, the front-page layout altered slightly in 1942 and the price increased to fifteen cents an issue from ten. The text portion kept its location but shrank in size and now featured a full-bleed photographic image. The photographic image took on even more importance. In a sense, a complete reversal occurred over the previous half decade. Whereas in 1937 the illustration sat on the frontpage layout, by 1942 the photograph was the front page and the text sat on top of the

\footnotetext{
${ }^{2}$ For an elaboration on female occupations during the Depression and World War II see S. J. Kleinberg, "Female Occupation in the 1920s and 1930s" in Women in the United States, 1830-1945 (New Brunswick, New Jersey: Rutgers University Press, 1999). 226.
} 
image. As usual, the title portion states the name of the magazine, the price and the month of publication along with the names of some of the featured fiction authors.

This new attitude towards working women seemed almost in direct opposition to the Depression mentality and the prevailing societal expectations of women's participation. While women in the 1920s and 1930s were better educated than the previous generations and expected to work before marriage, once married, cultural expectations remained similar to those of previous generations and women were expected to leave their careers and become housewives. ${ }^{3}$ Because of the hardships of the Depression, there was increased pressure on women to leave their careers or remain at home so the few available jobs could be given to men. ${ }^{4}$ At times, working couples were accused of "double dipping" in the small pool of available jobs. ${ }^{5}$ Some believe that given the separate working spheres of men and women, men would not have been interested in female careers. ${ }^{6}$ Others argue that while need propelled some men to seek out these distinctly female careers, they soon realized that employers were reluctant to fire women to hire their more expensive male counterparts. ${ }^{7}$ Conversely, some historians point out that many employers were reluctant to hire professional women at all since they were expected to leave once married. ${ }^{8}$ All agreed however that there was a considerable shortage of employment for both men and women during the Depression. Working wives were particularly stigmatized and sometimes accused of taking employment away from

\footnotetext{
${ }^{3}$ Jean V. Matthews, The Rise of the New Woman: The Women's Movement in America, 1875-1930, The American Way Series (Chicago: Ivan R. Dee, 2003), 179, and Jennifer Scanlon, Inarticulate Longings: Ladies' Home Journal, Gender, and the Promises of Consumer Culture (New York and London: Routledge, 1995), 50 and 80.

${ }^{4}$ S. J. Kleinberg, "The Great Depression," in Women in the United States, 1830-1945, 217.

${ }^{5}$ Stephanie Coontz, Marriage, A History: From Obedience to Intimacy or How Love Conquered Marriage (New York: Viking, 2005), 219.

${ }^{6}$ S.J. Kleinbert, "The Great Depression," in Women in the United States, 1830-1945, 217.

${ }^{7}$ Ibid.

8 Jean V. Matthews, The Rise of the New Woman, 179.
} 
both men and unmarried women. ${ }^{9}$ Only dire need excused working wives and particularly working mothers. ${ }^{10}$ This general attitude towards women prevailed throughout the $1930 \mathrm{~s}$. McCall's, as well as most women's magazines, echoed these sentiments by decreasing the amount of imagery of women on the job in the 1930s compared to the number of images of women at work in the 1920s. Despite a marginal increase in the number of working women during the thirties, ${ }^{11}$ there was a gradual decrease in visual representation of these women in $M c$ Call's, to the point of near total absence by the end of the Depression. Moreover, when working women such as movie stars were photographed, they were usually situated in a domestic setting rather than on the job. Even the numerous articles and works of fiction written by women for women, advocated homemaking as a profession instead of encouraging women to pursue a career. As Jennifer Scanlon explains in "Advertising Women: The J. Walter Thompson Company Women's Editorial Department" the lives of the women writing and editing would have been radically different from the ones they were advocating to their readership. ${ }^{12}$

Attitudes in the 1940s shifted dramatically in spite of women's employment and liberation efforts rather than as a direct result of them. ${ }^{13}$ The most significant change was perhaps in the range of employment that became available. ${ }^{14}$ While these occupations were seen as temporary because men were away at war, they nevertheless planted a seed, which eventually led to the second wave of feminism in the 1960s. This movement

\footnotetext{
${ }^{9}$ S. J. Kleinberg, Women in the United States, 1830-1945, 219.

${ }^{10}$ Jean V. Matthews, The Rise of the New Woman, 179.

${ }^{11}$ S. J. Kleinberg, "Economic Activity during Boom, Bust, and War," in Women in the United States, 1830-1945, 219 and 232.

12 Jennifer Scanlon, “Advertising Women: The J. Walter Thompson Company Women's Editorial Department," The Gender and Consumer Culture Reader, Jennifer Scanlon ed. (New York: New York University Press, 2000), 216.

${ }^{13}$ Women joined the war effort not for liberation but as aids to alleviate the man power shortage, Jean $\mathrm{V}$. Matthews, The Rise of the New Woman, 166.

${ }^{14}$ S. J. Kleinberg, Women in the United States, 1830-1945, 228.
} 
emphasized equal work for equal pay and a breakdown of the gender discrimination walls that excluded women from the workforce, particularly in traditional male employment. ${ }^{15}$

While Muray's front covers depicted a combination of the magazine's identity and the reader's aspirations, as seen in the cover image for September 1942, they also illustrate the changing role of women in society. They were evidence of the radical shift in cultural expectations of women's participation. Whether government sponsored war propaganda or simply a reflection of the times, women during the war in $\mathrm{McC}$ all's were depicted suddenly as economic producers and not solely as consumers. However, these women were not a complete departure from previous depictions. Despite their active participation in economic production, their physical attributes remain similar to Muray's models in earlier covers; they were attractive, clean and well made up. Lipstick was applied neatly and matched the cap. As before, the absence of age and visible marital status markers positioned these women to appeal to the entire perceived readership demography.

During the war, many mothers and homemakers joined the workforce. As in previous times, working women had the dual responsibility of worker and homemaker. However, responsibilities increased during wartime since many lost the aid of their spouses at home. ${ }^{16}$ In addition, women faced the new challenge of dealing with rationing, war stamps and food lines. As did the cover, the content of the magazine also evolved to include advice appropriate for a changing society. For instance, $M c C a l l$ 's featured the government sponsored column "Washington Bureau: Your Guide to Daily Living," which enumerated tips on wartime consumer behavior. In the September 1942 issue, the

\footnotetext{
${ }^{15}$ Jean V. Matthews, The Rise of the New Woman, 183.

${ }^{16}$ Karen Anderson, Changing Woman: A History of Racial Ethnic women in Modern America (New York and Oxford: Oxford University Press, 1996), 110.
} 
first tip encouraged women to borrow eggs or flour instead of driving to the store for a few items and risk wearing out the car tires. Tip number seven predicted an increase in store nurseries so that working mothers could do their grocery shopping more conveniently. And tip number twenty-three encouraged buying Victory Specials which included surplus in-season foods such as tomatoes, apples, cabbage and chicken that would otherwise go to waste. ${ }^{17}$

McCall's, which still regarded its primary audience as the homemaker, though temporarily employed, included articles and depictions of working women. ${ }^{18}$ In the September 1942 issue, the McCall's dress patterns featured in the "Style and Beauty" section depicted dresses that were simpler, more practical and more conducive to

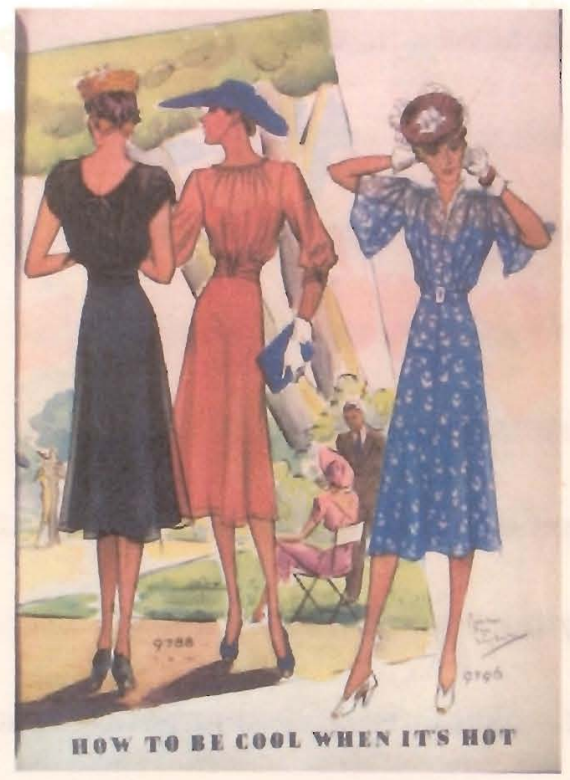

8.2. [McCall's Pattern Illustrations] July 1938

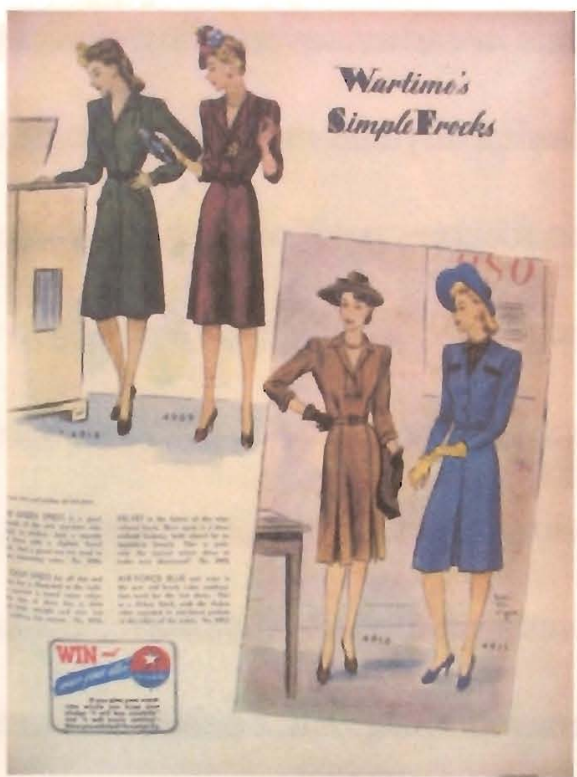

8.3. [McCall's Pattern Illustrations] September 1942

working women's lifestyle than those in the inter-war years as can be seen when comparing the dresses to those of July 1938. Given the simpler styles, the dresses may

\footnotetext{
${ }^{17}$ Mc Call's, "Washington Bureau: Your Guide to Daily Living," September 1942.

18 "Women's magazines envisioned jobs only for the duration." S. J. Kleinberg, Women in the United States, 1830-1945, 228.
} 
also have been less time consuming to sew. Additionally, because of rationing, they certainly involved less materials and decoration.

Advertising sections also saw an increase in the amount of workingwoman depictions, often featuring a woman at work by day and glamour girl by night. The verso of the September 1942 cover was an ad for Cannon towels and features a woman in uniform. The adjacent page depicts graphically the story of an aspiring model who cannot find work despite her good looks; that is, until a photographer tells her about "pink toothbrush." After having solved the problem by using Ipana toothpaste, she becomes a model and is depicted posing for a photographer as a factory worker in uniform and goggles. While Ipana toothpaste had used the threat of pink toothbrush as a scare tactic in the past, women were usually warned against loss of love and charm rather than the loss of potential employment. ${ }^{19}$

Muray and partner Ruzzi Green's split covers of the September 1943 "Homemaking" and "Style and Beauty" sections advocated women entering the workforce during the war yet equated this to performing one's patriotic duty rather than contributing to the economy. The first diptych, used for the issue's "Homemaking" cover, depicts women in factory uniform standing in front of a conveyor belt full of tomatoes. Below them is another image of a soldier pointing a gun amidst the wilderness. The text reads "BY DOING THIS They FREE Him TO DO THIS." The second image, used for the "Style and Beauty" cover, is similar in subject matter but features a woman repairing a toaster and a sailor looking through a telescope. The sign behind her confirms that she has taken over her husband's repair business while he is away at war. This cover reads, "BY DOING THIS She FREES Him TO DO THIS." Muray and Ruzzi’s images

\footnotetext{
${ }^{19}$ Ibid., 2.
} 
validated the importance of women's work and contribution to the war effort. Perhaps more subtle, they also confirm that women's participation was not seen as an economic endeavor but a patriotic one, and therefore necessary only for the length of the war.

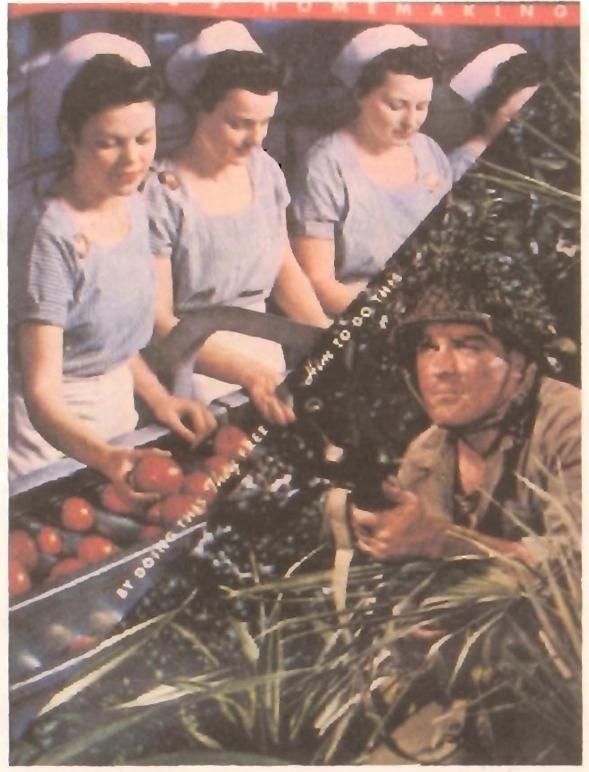

8.4. "BY DOING THIS They FREE Him TO DO THIS"

"Homemaking" September 1943

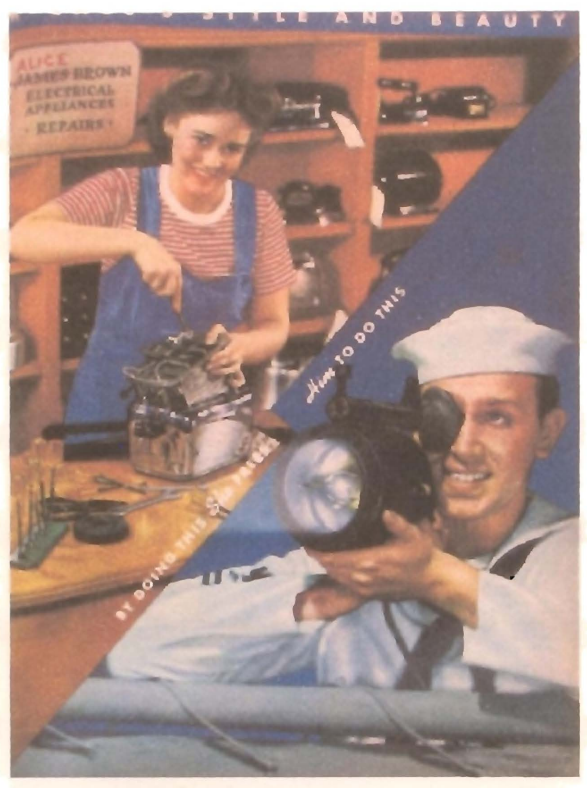

8.5. "BY DOING THIS She FREES Him TO DO THIS"

"Style and Beauty" September 1943

During the Depression, women were seldom photographed working in Muray's editorial photographs for McCall's. One known exception is an African American woman putting away linen in a closet behind a young Caucasian girl. ${ }^{20}$ This image certainly says more about race relations than it does about white women's presence in the workforce. Since homemaking was a cultural expectation, when a married woman did work, it was implied that it was out of necessity and not a lifestyle choice. In general, there was some consensus that the lack of employment opportunities during the Depression was at least in part caused by the fact that more women were working, despite the distinctly separate working spheres. This point was commonly raised instead of examining the system of

\footnotetext{
${ }^{20}$ Mc Call's "Homemaking," February 1937.
} 
over production, under consumption, and the overall inadequate distribution of wealth. ${ }^{21}$ As previously mentioned, married women were particularly stigmatized because they took employment away from both men and unmarried women who had no husbands to rely on for support. It is perhaps in part for these reasons that McCall's, a women's complete cultural resource, chose an uncontroversial and apolitical perspective. Muray's images for McCall's during the Depression visually excluded working women by promoting and preserving women's life in the home.

However, after the United States' entrance into the war, Muray's photographs encouraged women to help with the war effort and seek employment even in domains previously exclusive to men. Moreover, $M c C$ all' $s$ altered its content appropriately to include working women even if only for the duration of American participation, just as the repair woman in figure 8.5 was only there as a substitute while her husband was away at war. Muray's visual depictions of working women increased but did not surpass the number of his representations of women as homemakers. However, the two did continue to coexist for the length of the war. During the war, gender roles diversified and women were depicted as both economic producers and consumers. From a consumer perspective, the magazine offered its readers mixed messages about their role; advertisers sought to continue encouraging consumerism while the war effort encouraged frugality, simplicity, and condemned consumerism through scare tactics based on immoral overindulgences. Generally speaking, American society encouraged women to work as part of fulfilling a patriotic duty rather than an economic endeavor. Hence, once the war ended, images of working women vanished from $M c$ Call's magazine pages.

\footnotetext{
${ }^{21}$ Jackson Lears, Fables of Abundance: A Cultural History of Advertising in Modern America ((New York: Basic Books, 1994), 241.
} 


\section{Advertising in 'McCall's'}

Although it is possible that from production to reproduction, Nickolas Muray's images underwent the most amount of interpretive change when used for advertising in McCall's magazine, it is as difficult to ascertain as his advertising photographs are challenging to contextualize. Unlike editorial commissions, photographs used in advertising are not typically credited to the photographer. Perhaps this says as much about the authorship of the image as it does about the ownership of the image since "the editorial photographer is chosen for his or her personal style and interpretation with usually little, if any, direction from an art director. The traditional advertising photographer, on the other hand, is much more restricted." However, the presence of advertisements in McCall's cannot be disregarded since they shared a symbiotic relationship with the magazine. It is for these reasons that this chapter examines one of Muray's images in the context of advertisements in McCall's during the Depression and World War II.

\footnotetext{
${ }^{1}$ Robert Sobieszek, The Art of Persuasion: A History of Advertising Photography (New York: Harry N. Abrams, 1998), 99.
} 


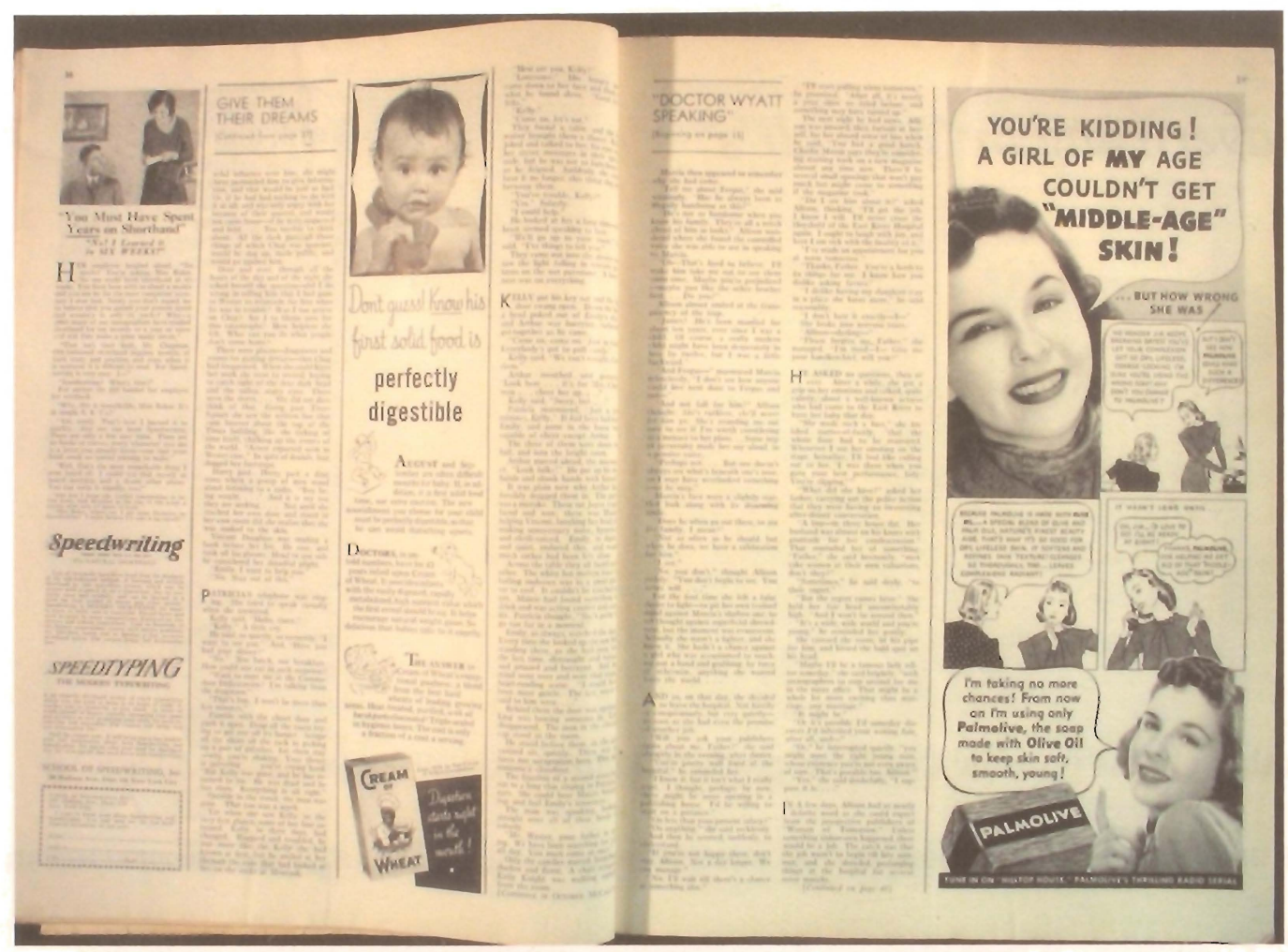

9.1. A Cream of Wheat advertisement in McCall's September 1938

The Cream of Wheat advertisement was photographed by Muray and published in the September 1938 issue of McCall's. The image was printed on page thirty-eight of the "News and Fiction" section, between story columns and above the accompanying copy. The photograph is a school-picture size headshot of an infant on a toy telephone who stars out at the viewer, mouth slightly open and looking quite adorable. Below the portrait of the child is the copy for the Cream of Wheat advertisement and an illustration of the cereal box. Although the original photograph was produced in colour, the advertisement is reproduced in black and white. Despite available colour technology, black and white photography was prominent in Depression advertising because it was less expensive to replicate. Thus, bold headlines and multiple fonts were used to grab the viewer's attention. 


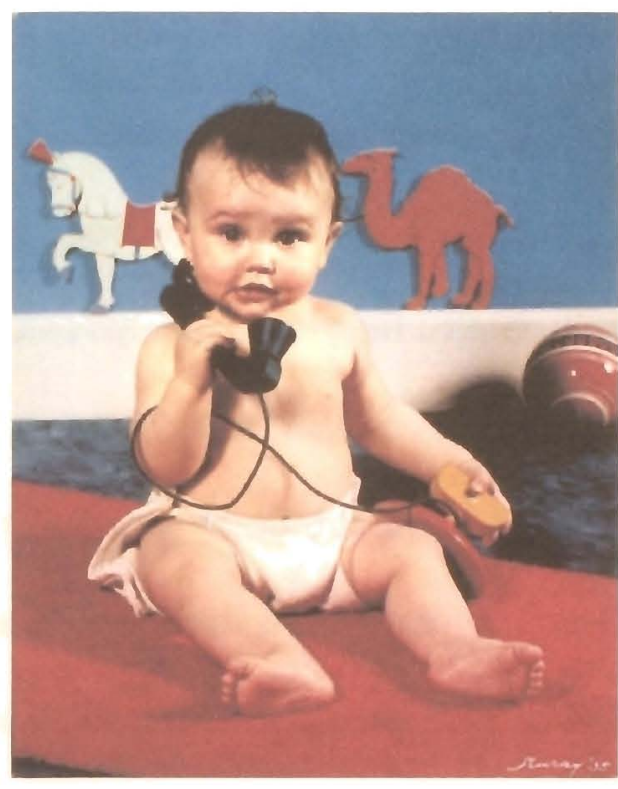

9.2. Cream of Wheat advertisement Courtesy of George Eastman House

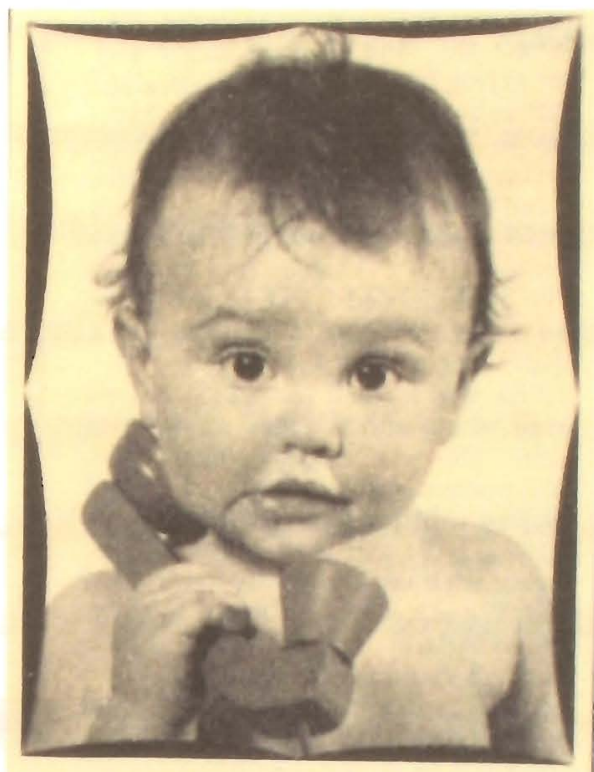

9.3. Cream of Wheat advertisement in McCall's September 1938

In Muray's original colour carbro composition, the infant is situated in the center of the scene. While there is no suggestion of gender in the infant's apparel, there is perhaps a clue in the composition; the colours are red and blue and there is a wooden camel and a horse in the background. The boy is white and has brown eyes and brown hair. His eyes and eyelashes have been slightly retouched and darkened. He is seated in his cloth diaper on a bright red area rug playing with a red, yellow and blue telephone. The cord wraps playfully around the baby's arm as he looks out at the viewer, mouth slightly open, appearing very healthy and content. Under the area rug lies a blue carpet of a slightly darker hue than the blue background wall. Between the wall and carpet is the white molding on which rest the wooden animals. In addition, there is a red ball behind and to the left of the child. The colour scheme is red, white and blue. These colours are particularly vivid even for a carbro.

Looking at the version that was published in the September 1942 issue of McCall's, it is clear that all non-essential details have been cropped out. What remains is 
a headshot of an infant on the telephone. When going from original to reproduction, the composition was altered in such a way as to remove any details remaining in the image. The background has been painted white. No longer visible are the cloth diaper, rubber ball, area rug and wooden animals. The cropped portrait, context free, is extremely versatile. This infant could be from any time or any class background and could have been used for a number of possible advertisements, including those for the new disposable diapers. Yet it was used for a Cream of Wheat advertisement and, according to the verso of the carbro print in the collection of the George Eastman House, was commissioned by the $J$. Walter Thompson advertising company.

The layout is typical of the editorial or tabloid style advertising of the Depression. $^{2}$ The copy makes use of four different fonts as well as bolding and underlining. The design layout is not a continuous style but a combination of ideas that are visually separated from each other by the use of illustration and font changes. The text adopts the problem/solution approach where the image of a happy child naturally represents the solution. The copy reads, “Don't guess! Know his first solid food is perfectly digestible" The font changes between the words "is" and "perfectly." The copy further states that choosing the right first food can prevent the problems of upset stomach. In addition to this, an unsubstantiated medical claim supports the choice of Cream of Wheat for the baby's first food. Finally, "THE ANSWER to Cream of Wheat's exceptional goodness: a blend from the best wheat of leading growing areas. Heattreated, purified, with all harsh parts eliminated! Triple-sealed in hygienic boxes. The cost is only a fraction of a cent a serving." In its original form, Muray's photograph is a

\footnotetext{
${ }^{2}$ Jackson Lears, Fables of Abundance: A Cultural History of Advertising in Modern America ((New York: Basic Books, 1994), 238.
} 
wholesome photograph of a happy baby playing with a toy. Yet within the context of the advertisement, it is commercial in nature. This consumerist intent only escalates when imbedded in the context of the magazine, which also contains advice on consumption and some one hundred and thirty other advertisements.

The copy for Cream of Wheat is only suggestive of the ruthless advertising usually so present during the Depression, yet still makes use of the "use this product or else" ${ }^{3}$ method. As just stated, the text uses a multitude of fonts, bold and underline, all with the intention of grabbing the reader's attention. Much more ruthless, and perhaps more typical, is the Palmolive advertisement on the adjacent pages. It relates the story of a woman whose beau "breaks dates" with her because of her early onset of "middle-aged skin;" a direct result of not using the right kind of soap. The problem of middle-aged skin is remedied at the end of the story when the heroine switches to Palmolive soap.

When discussing advertising during the Depression, historians and critics tend to exemplify the particularly exaggerated hard sell techniques that impudently used fear to sell, such as the Palmolive scenario described above. ${ }^{4}$ Yet also present--though much less critiqued - are those similar to the Cream of Wheat advertisement which focus on the positive benefits of choosing and consuming a given product. While also ruthless and potentially as deceiving, these two styles were different in their approach. One placed emphasis on the consequences of not choosing a product and the other advised on the benefits from using the product. ${ }^{5}$ The Cream of Wheat advertisement advises on the

\footnotetext{
${ }^{3}$ Roland Marchand, Advertising the American Dream: Making Way for Modernity, 1920-1940 (Berkeley, Los Angeles and London: University of California Press, 1985), 300 Jackson Lears, Fables of Abundance: A Cultural History of Advertising in Modern America (New York: Basic Books, 1994), 238, and Juliann Sivulka, Soap, Sex and Cigarettes: A Cultural History of American Advertising (New York: Wadsworth . Publishing Company, 1998), 198.

${ }^{4}$ lbid.

${ }^{5}$ Roland Marchand, "Advertising Advice and Added Value" in Advertising the American Dream, 347.
} 
health benefits of giving your child the cereal as her or his first solid food. Throughout Muray's time with McCall's advertising increasingly focused on the benefits of consumption, especially near the end of the Depression.

Nevertheless, during the Depression, advertising in McCall's seldom reflected the state of the nation. ${ }^{6}$ While the problems of over production and under consumption plagued the American economy, the magazine's pages were filled with threats of lost love, failure to find a husband, or keep a husband and raise healthy and intelligent children; problems that could be solved by purchasing the product in question. Dollars were scarce and advertising had turned merciless. Yet, near the end of the Depression and the beginning of World War II, there was a noticeable rise in positive advertising, much like the Cream of Wheat advertisement. This technique placed more emphasis on the promises of consumption than on immediate benefits or effects of improper consumption. For instance, Palmolive does not simply rid you of middle-aged skin; it allows you to keep the man of your dreams.

Photographs had an increasing presence in $M c$ Call's advertisements during this time. In the September 1938 issue, all but one full-page advertisement used photographic reproductions as did numerous smaller ads. The reasons for photography's rise in popularity were numerous. ${ }^{7}$ One important reason was simply that photographers were generally less expensive to commission than illustrators. Furthermore, the popularization of news as editorial photography increased the medium's visibility and potential in other areas. Not surprisingly, advertising often mimicked the aesthetics of photojournalism. In addition, there were several important technological advances in both colour

\footnotetext{
${ }^{6}$ This denial was true in women's magazine advertising as a whole, Jackson Lears, Fables of Abundance, 236.

${ }^{7}$ Ibid., 323.
} 
photographic and printing processes that facilitated reproduction. ${ }^{8}$ Yet perhaps the most important factor was the widespread acceptance of the photographic medium by the advertising companies and the general population. Whereas in the 1920s photographic advertising was often regarded as a step down in design by advertisers, by the 1930s it had become the universal language that related to the viewers "real life" experiences." The result was a prevailing consensus among advertisers that the innate truth in photography paired with ruthless copy could entice anyone into buying a product. ${ }^{10}$

Advertising was crucial to McCall's; the magazine depended on advertising revenue to supplement income since the price of an issue was below production cost. ${ }^{11}$ Advertisers also depended on the magazine since it offered them the great opportunity to reach millions of female consumers. Titles were created to emphasize the importance of women's economic activity in the marketplace. Referred to as "Mrs. Consumer," "Chief Consumption Officer" ${ }^{13}$ and "General Purchasing Agent,"14 the female consumer was the spender of the nation's wealth. She was responsible for the disbursement of at least eighty percent of the household income. ${ }^{15}$ Companies advertising in $M c$ Call's competed

${ }^{8}$ Robert Sobieszek, The Art of Persuasion, 69.

${ }^{9}$ Jackson Lears, Fables of Abundance, 322 and 324.

${ }^{10}$ Ibid.

${ }^{11}$ Mary Ellen Zuckerman, A History of Popular Women's Magazines in the United States, 1792-1995 (New York and Oxford: Oxford University Press, 1991), 25.

${ }^{12}$ This title was used periodically throughout the twentieth century in reference to the female consumer. For one example see Susan Strausser," Selling Mrs. Consumer," in Never Done: A History of American Housework (New York: Henry Holt, 2002), 242.

${ }^{13}$ Hine uses this title to acknowledge the importance of women's purchasing decisions and how the choices they make create an identity for household members. "Her purchases constitute a reality, a morality and an image for members of the household" Thomas Hine, "Why Women Shop," in I Want That: How We All Became Shoppers (New York: HarperCollins, 2002), 24.

${ }^{14}$ Here Marchand makes the connection between consumerism and business by demonstrating how much her spending dollars influenced advertisements. "The leading lady claimed the largest role in advertising tableaux. Her qualifications for stardom were scarcely debatable; everyone acknowledged that she made at least 80 percent of all consumer purchases. To foster identification and illustrate consumer satisfaction, . advertisers kept her in the limelight." Roland Marchand, "Modern Woman as Businesswoman: The Little Woman, G.P.A." in Advertising the American Dream, 167.

${ }^{15}$ Ibid., 167. 
for her purchasing dollars because she was responsible for what the family ate, wore and the overall appearance of the household. Through her purchases, she created her household's identity. ${ }^{16}$

In summary, advertisers shared a symbiotic relationship with $M c$ Call's during the Depression and World War II. Each depended on the other to generate income. Advertising revenue was vital to McCall's, and the presence of advertisements helped shape the identity of the magazine. Photographic images were placed prominently in advertisements as they were believed to relate better to the viewers' experiences. A photographic advertisement was a window into someone else's reality, someone whose life had been enhanced by the consumption of a given item. Using fear and the promise of a better life, advertisements educated, directed and misled female consumers towards purchases and product consumption.

\footnotetext{
16 "Her purchases constitute a reality, a morality, and an image for members of the household," Thomas Hine, I Want That, 24.
} 


\section{Conclusion}

This thesis project examined aspects of gender and consumer culture in Nickolas Muray's photographs for McCall's magazine from 1933 to 1945 . The study emphasized the fluidity of meaning from image content to magazine context. While photographing for McCall's, Muray's artistic abilities and technical mastery gave "magic" to the images without compromising the ideologies of the magazine. ${ }^{1}$ Described by Solomon Grimberg as a perfectionist, Muray was committed to giving his customers what they desired. ${ }^{2}$ His editorial photographs for $M c$ Call's had the mission of representing the magazine's identity and the readers' aspirations. Concurrently, they had to appeal to potential advertisers at a time when advertising dollars were scarce and competition was fierce.

McCall's magazine was designed for a broad female audience that included as many groups of women as it excluded. During the Depression, the magazine perceived its readership as white, middle class homemakers between the ages of twenty-five and fortyfive living in urban or suburban areas. Its perception excluded any variations of race, class, sexual orientation, marital status, parenthood and occupation, with the exception of World War II when working women were included. Further divisions were made within

\footnotetext{
${ }^{1}$ Salomon Grimberg, e-mail message to author, June 19, 2007.

${ }^{2}$ Ibid.
} 
the magazine to appeal to its various readership groups. The "Homemaking" section sought the attention of mothers and homemakers, while the "Style and Beauty" section often called attention to pre-marital romance and a younger audience. The "News and Fiction" section was designed for both the younger and older audiences, which combined was the entire perceived readership.

Nickolas Muray's editorial photographs for McCall's romanticized this multifaceted yet limited version of the American woman. In his depiction, the McCall's woman was glamorous and content with the simplicity of domesticity; she longed for love, spent time with her children and partook in consumer culture. These aspects of her role did not conflict; rather they complemented one another and characterized the diversity and limitations of her identity. Furthermore, her persona was affected by the context of a magazine which continuously amplified her identity as a consumer. Wants for products were advocated under such guises as wholesomeness and true womanhood. During the Second World War, her role expanded to include a contribution to economic activity as part of her patriotic duty. As a representative of a magazine with a readership in the millions, Muray's images for. McCall's reflected an expectation and perpetuated a stereotype of the American woman.

However, just as gender and consumer culture complemented one another in Muray's images in McCall's by portraying a diversified version of American women, they also depicted women as subordinate to men in the economic world. She may have been the spender of the nation but her depictions as well as her actions remain “depoliticized." As Jennifer Scanlon explains, "When men spend money, they commit a 
political act; when women spend money they commit a social or cultural act." Even during the war, images of working women were equated to fulfilling a patriotic duty. In Muray's images and in the magazine, the act of consumption is not emphasized as contributing to an economic system, instead it is the pleasure derived from consumption that is accentuated.

Nevertheless, Muray's images gave readers a vision of themselves where their work, contributions and sacrifices were validated. A woman may have spent her time cleaning, childrearing and spending, but these acts were so important that they justified a plethora of images, advice columns and advertisements to help her make the best decisions for herself and her family. The woman on the cover may have represented the American housewife, but this homemaker was confident, luxurious and captivating. Muray's cover images were the gateways to promises and escapes where the homemaker was the heroine and where her work mattered. His photographs for McCall's depicted a fluid and utopian vision of women's domestic life amidst the promises of consumer culture.

\footnotetext{
${ }^{3}$ Jennifer Scanlon, Inarticulate Longings: Ladies' Home Journal, Gender, and the Promises of Consumer Culture (New York and London: Routledge, 1995), 229.
} 
Appendix

Nickolas Muray's Production for 'McCall's, '1933-1945

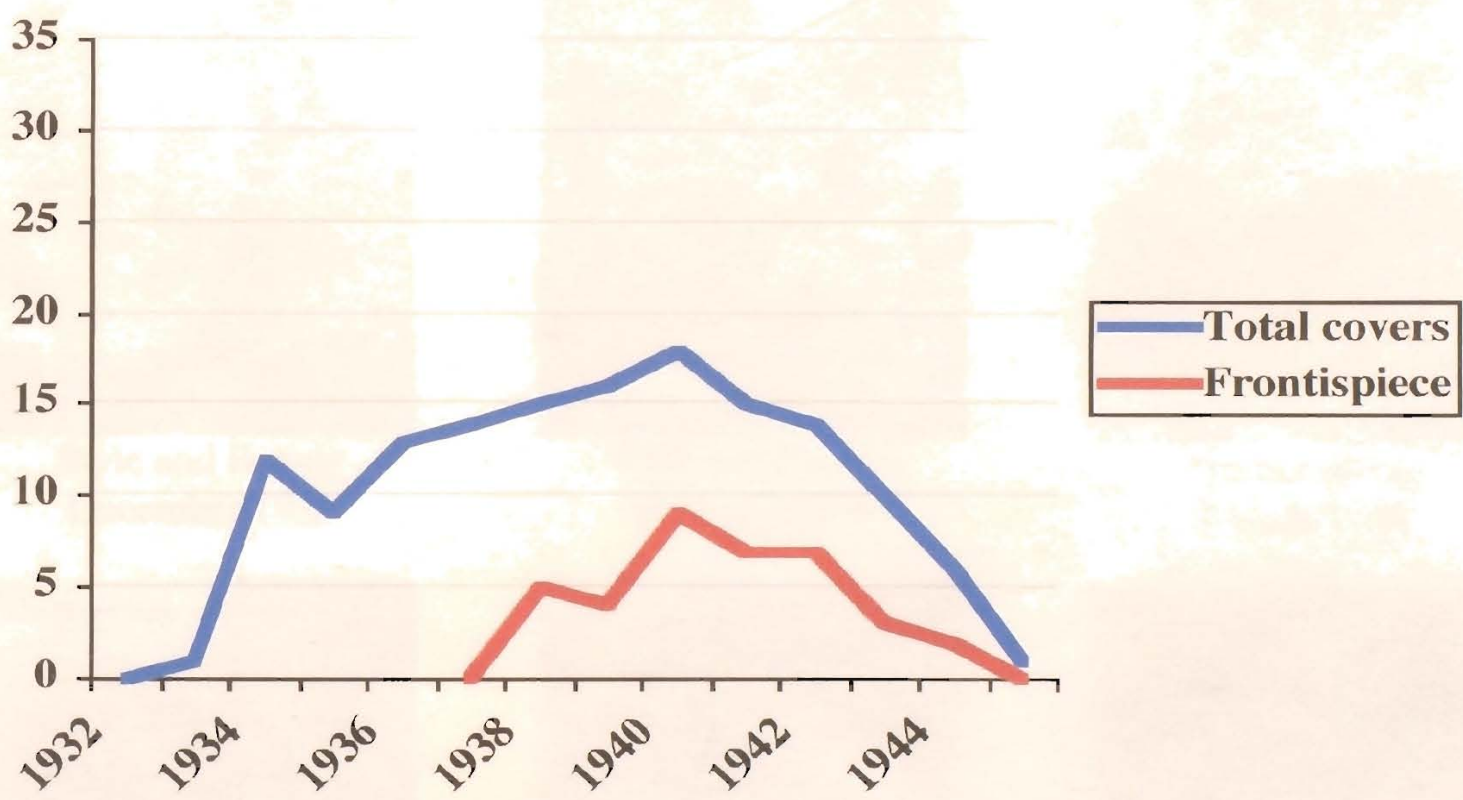

Date of publication 
Appendix

$B$

Known 'McCall's' Photographs by Nickolas Muray

1933-1945

1933-1934

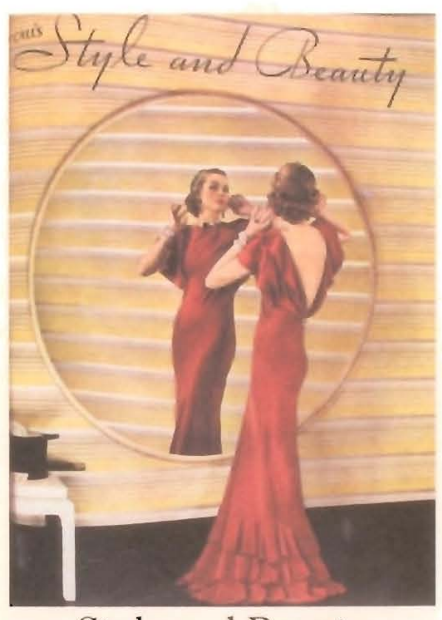

Style and Beauty

December 1933

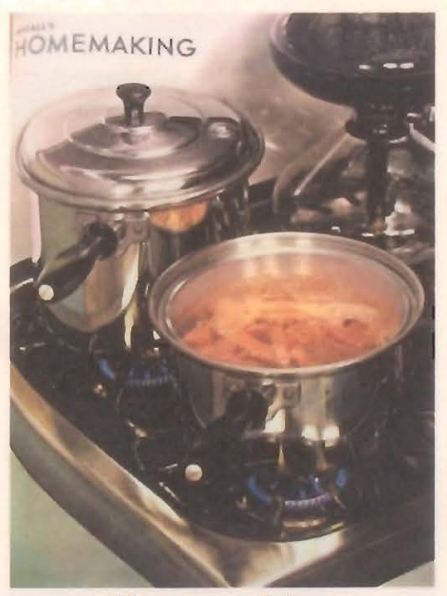

Homemaking

April 1934

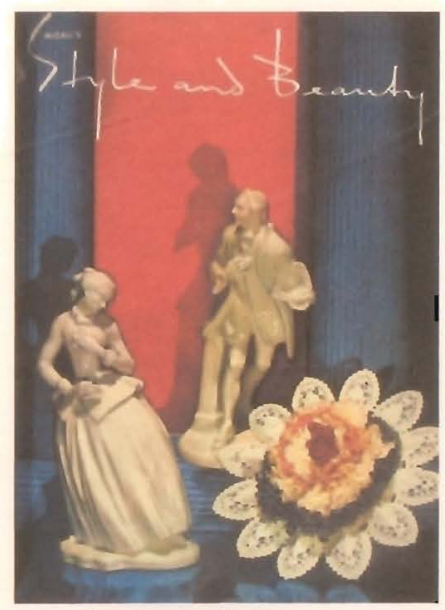

Style and Beauty February 1934

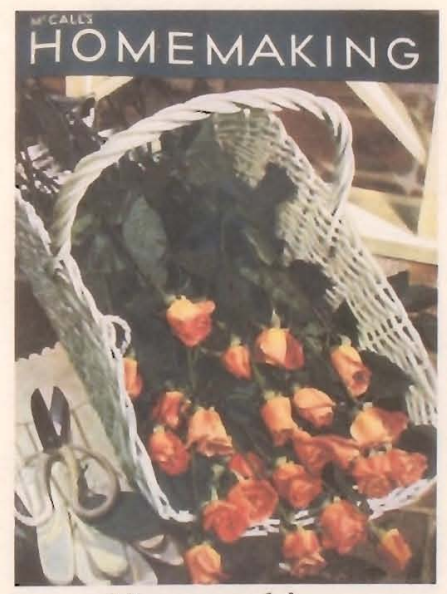

Homemaking May 1934

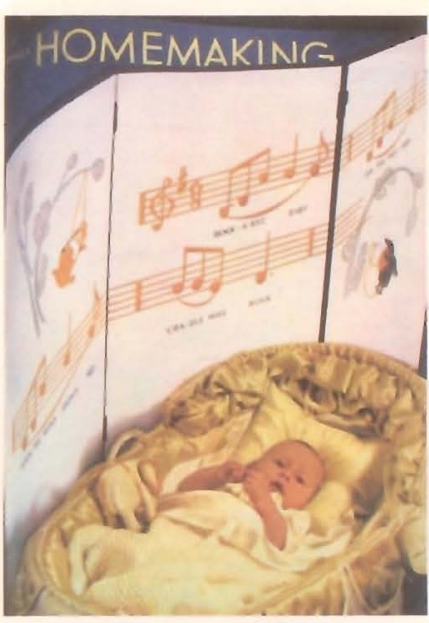

Homemaking March 1934

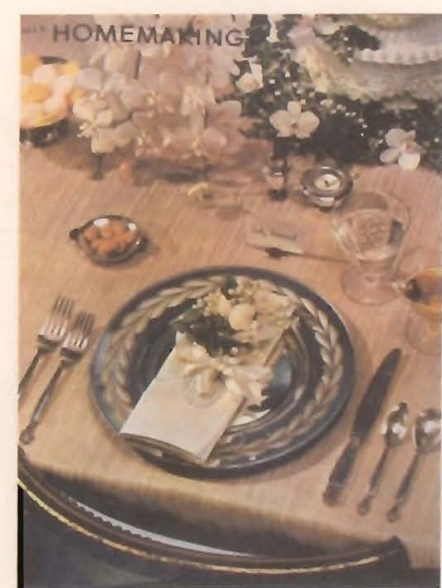

Homemaking. June 1934 


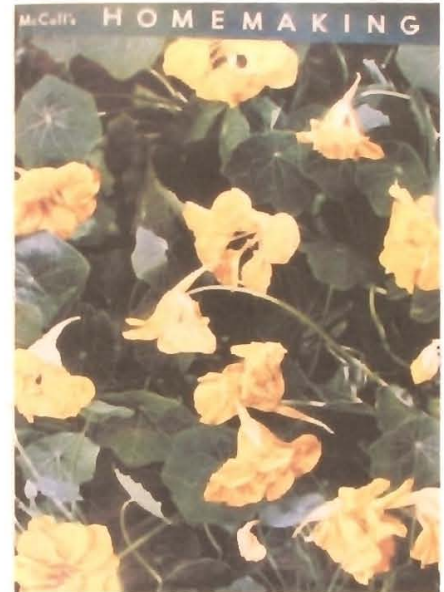

Homemaking July 1934

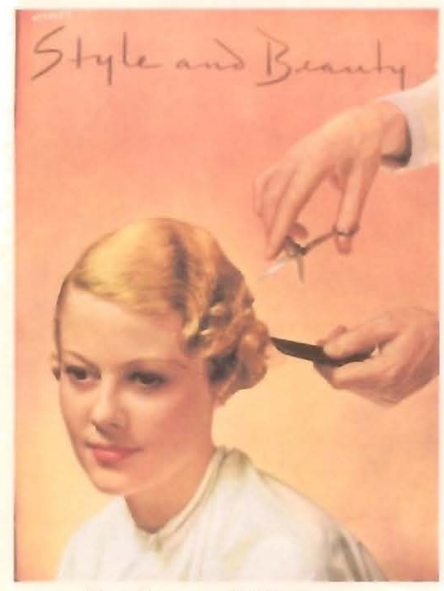

Style and Beauty October 1934

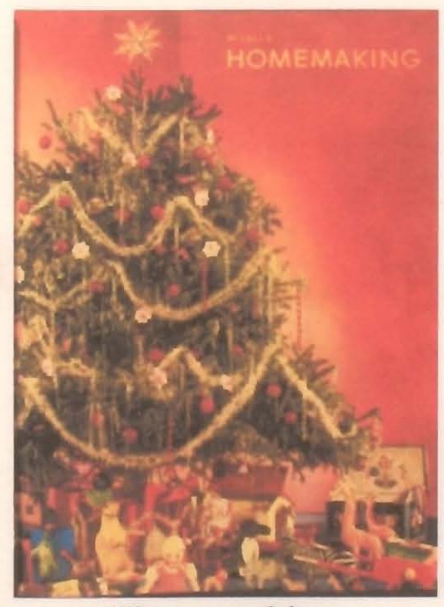

Homemaking January 1935

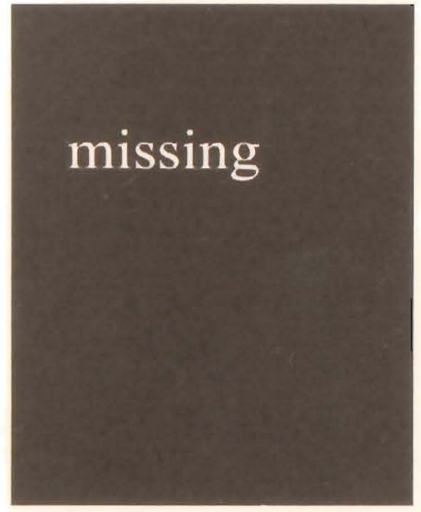

[woman by pool] Style and Beauty July 1934

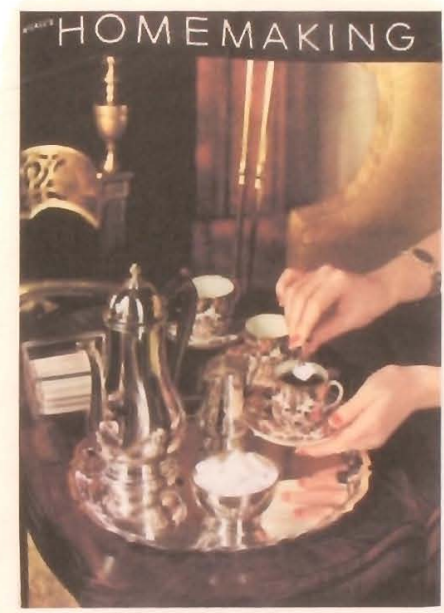

Homemaking

November 1934

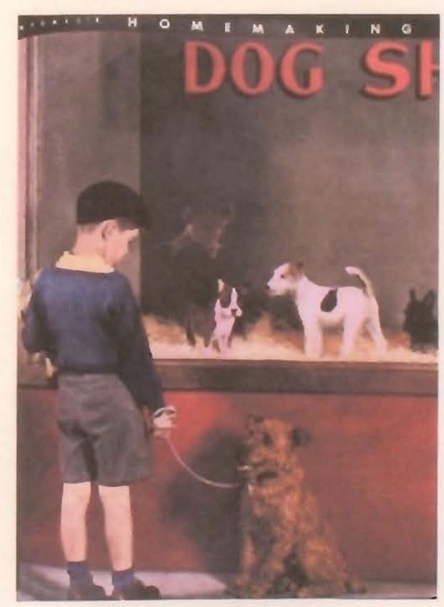

Homemaking

March 1935

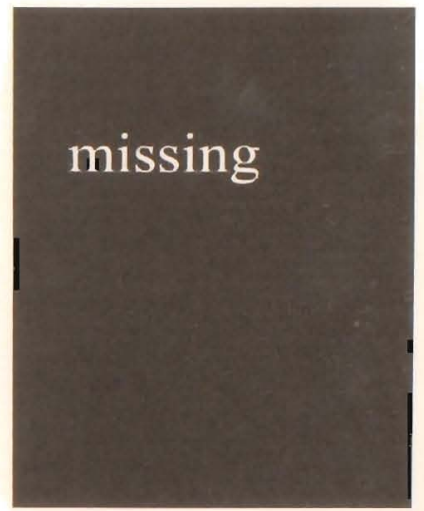

[summer drinks] Homemaking August 1934

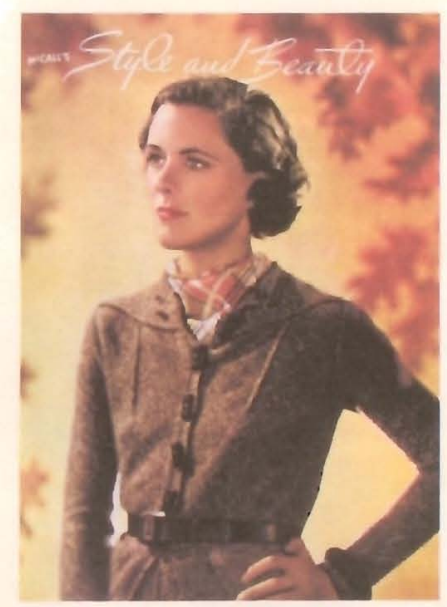

Style and Beauty November 1934

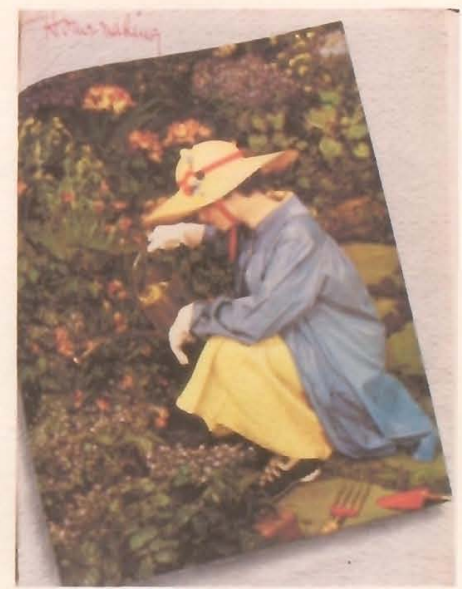

Homemaking June 1935 


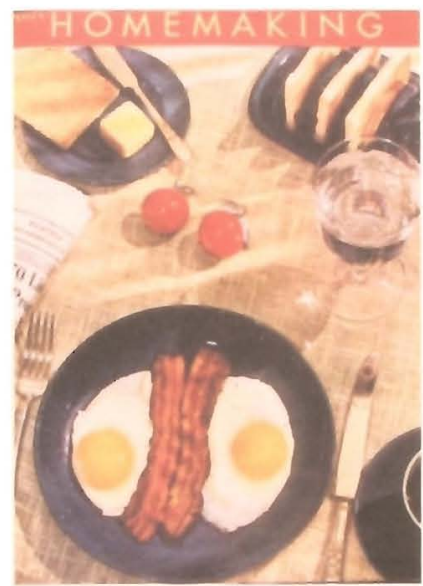

Homemaking

July 1935

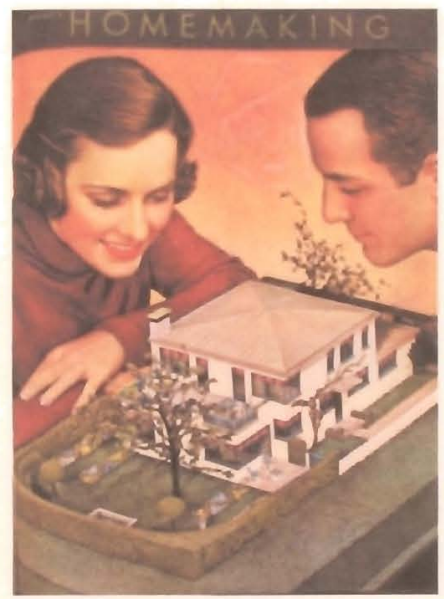

Homemaking

October 1935

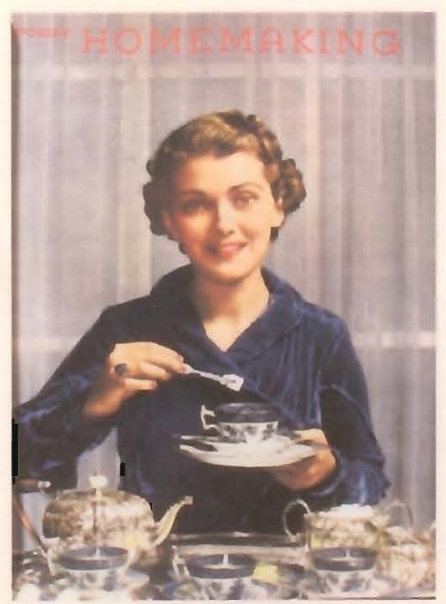

Homemaking

January 1936
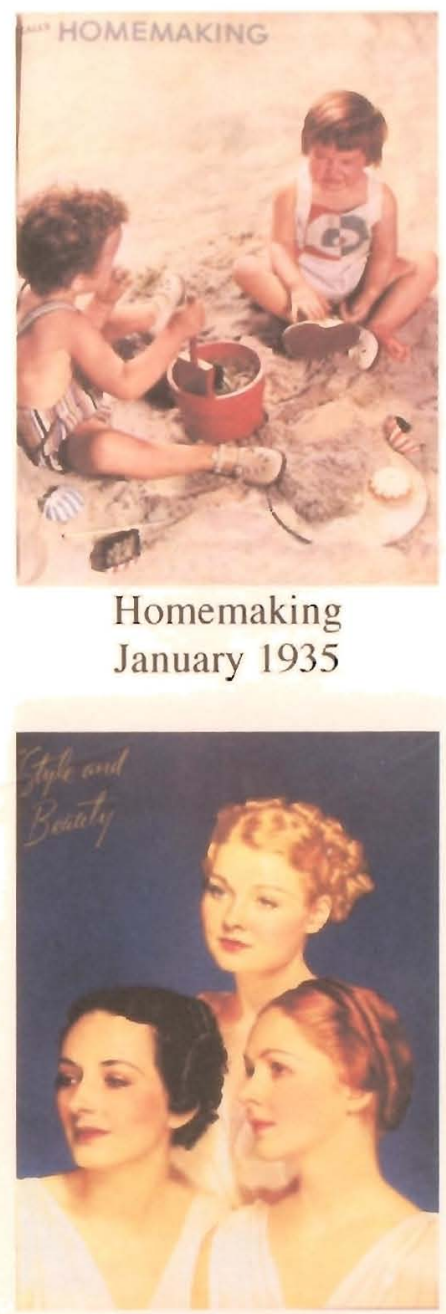

Style and Beauty

November 1935

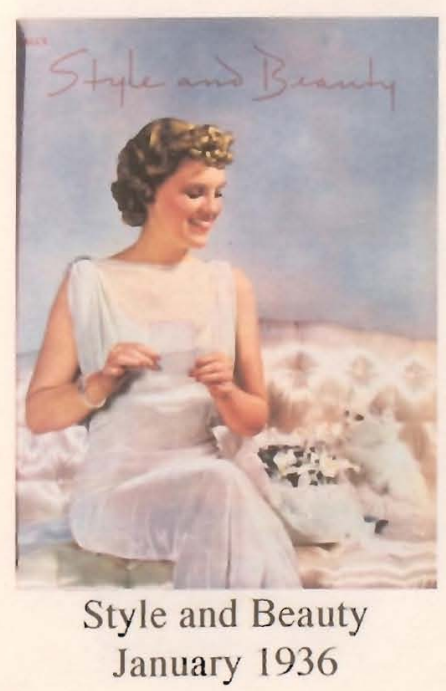

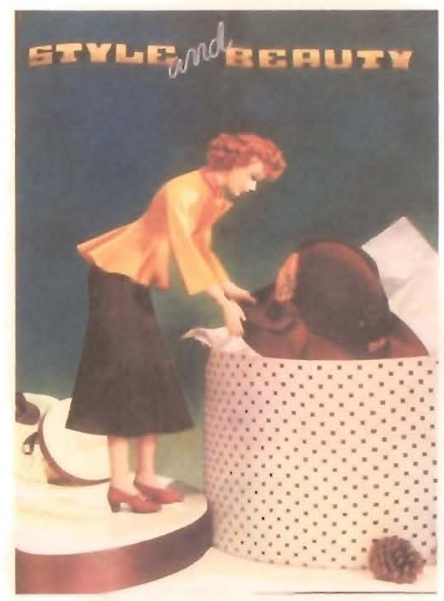

Style and Beauty

September 1935

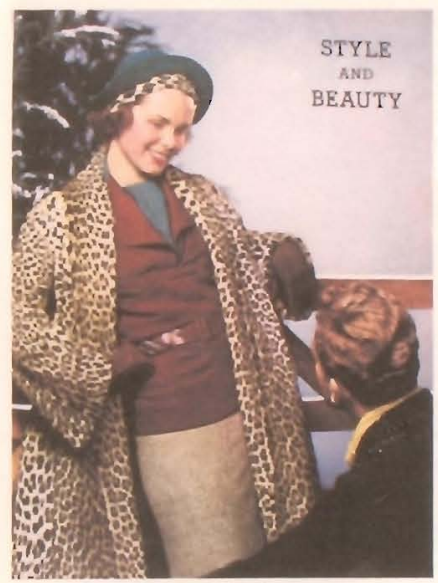

Style and Beauty

December 1935

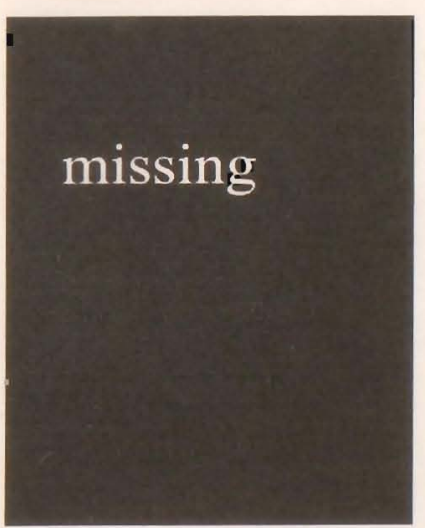

[woman and perfume] Style and Beauty February 1936 


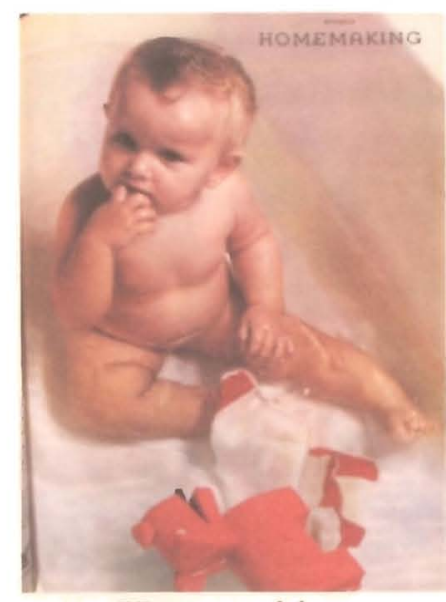

Homemaking

March 1936

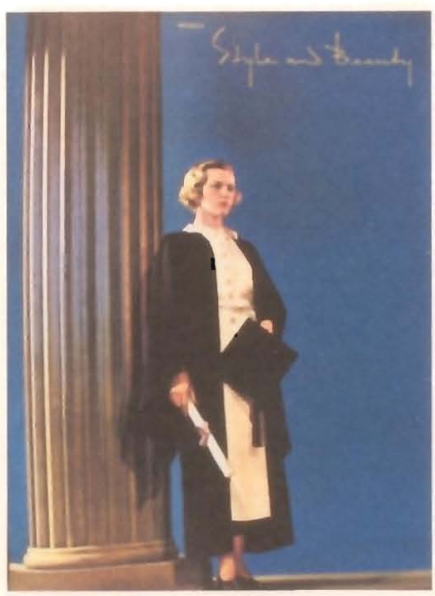

Style and Beauty

June 1936

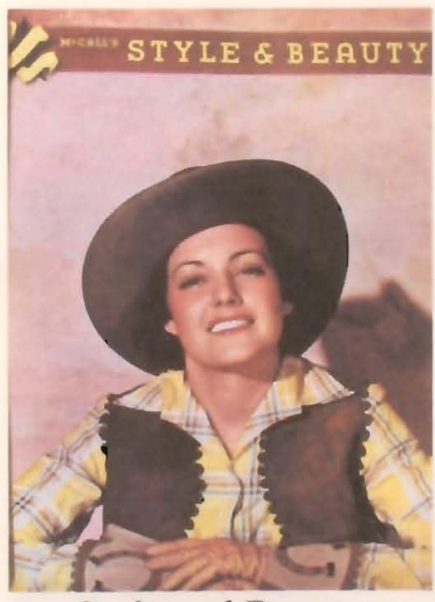

Style and Beauty

August 1936

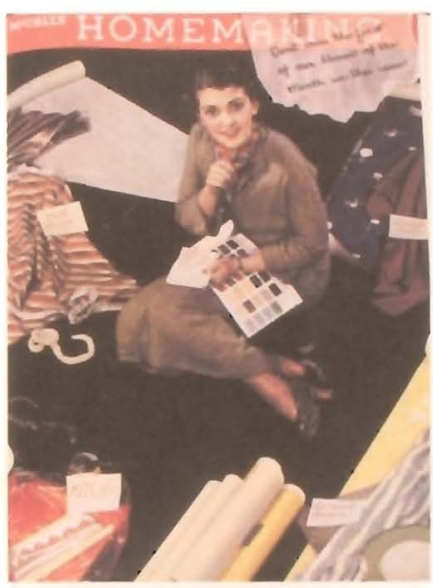

Homemaking

April 1936

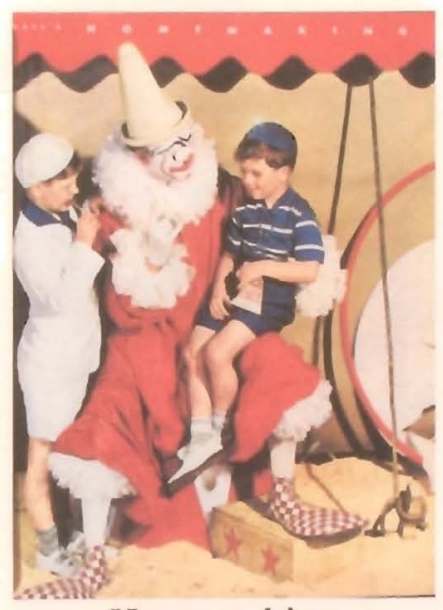

Homemaking July 1936

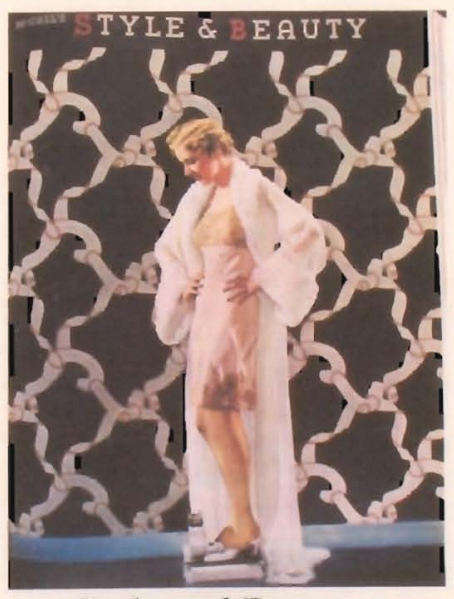

Style and Beauty

September 1936

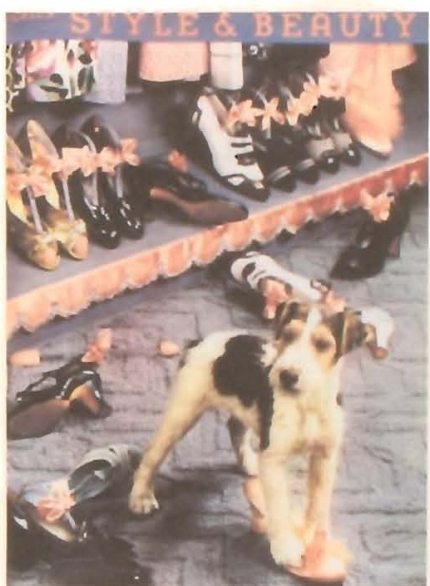

Style and Beauty April 1936

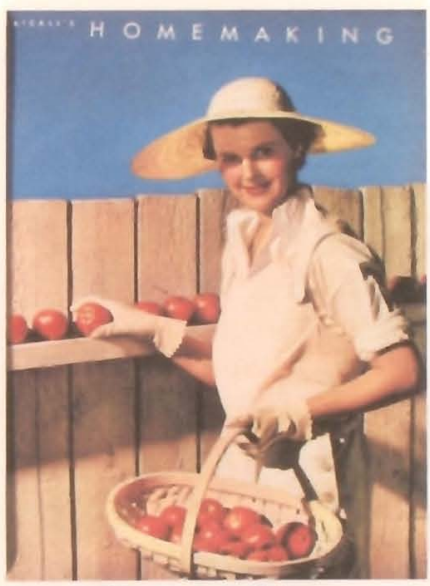

Homemaking

August 1936

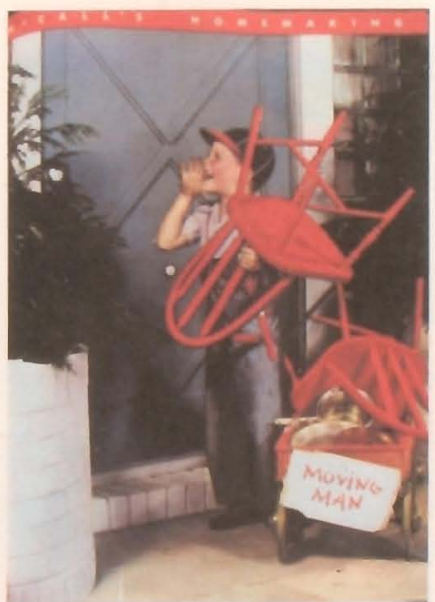

Homemaking

October 1936 


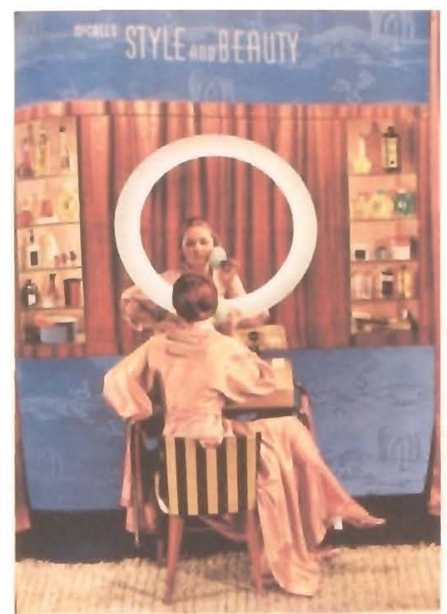

Style and Beauty

October 1936

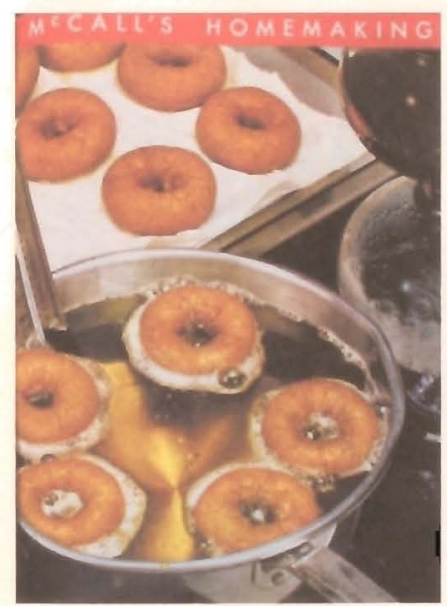

Homemaking

March 1937

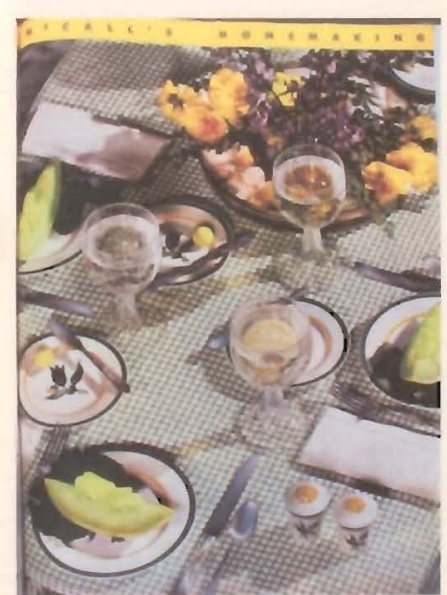

Homemaking June 1937

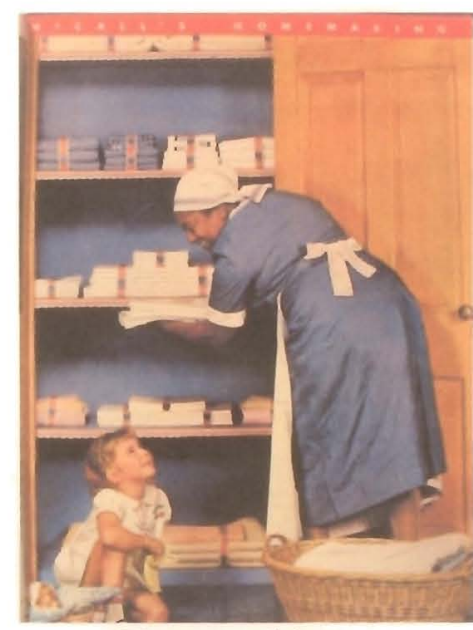

Homemaking

February 1937

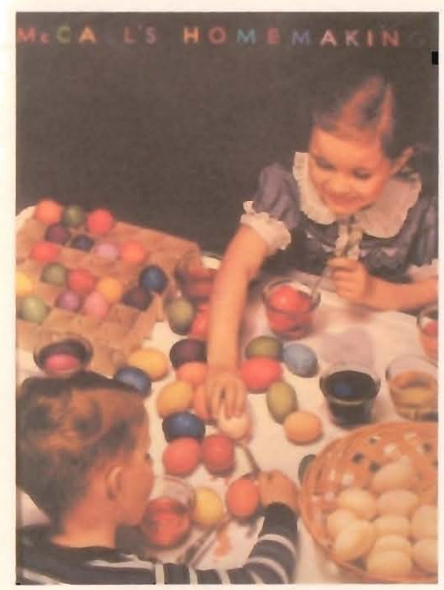

Homemaking

April 1937

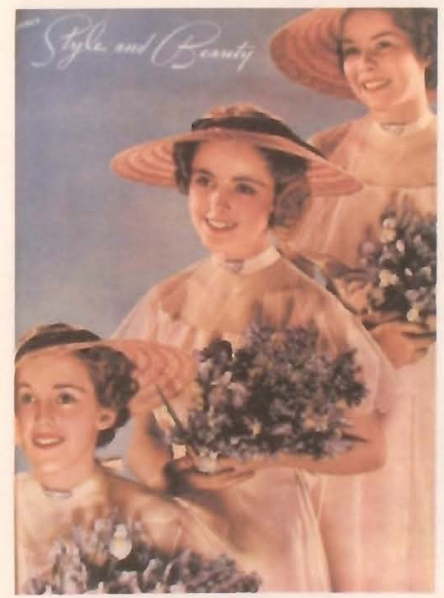

Style and Beauty

June 1937

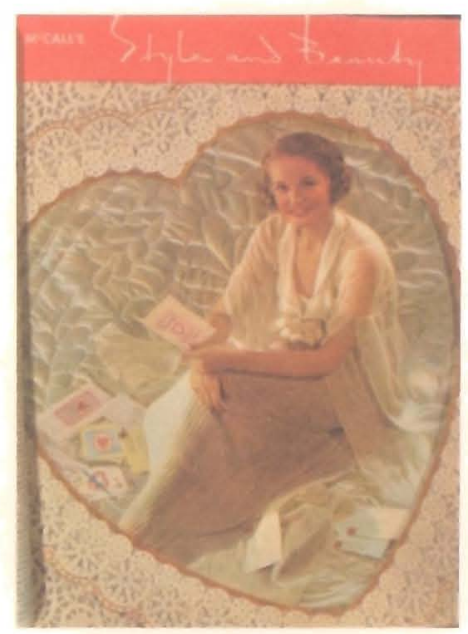

Style and Beauty

February 1937

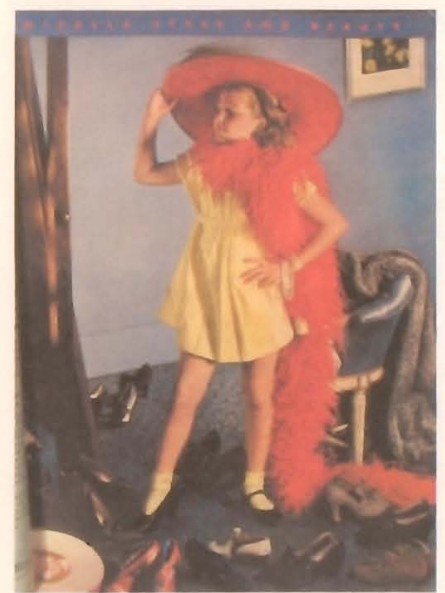

Style and Beauty

April 1937

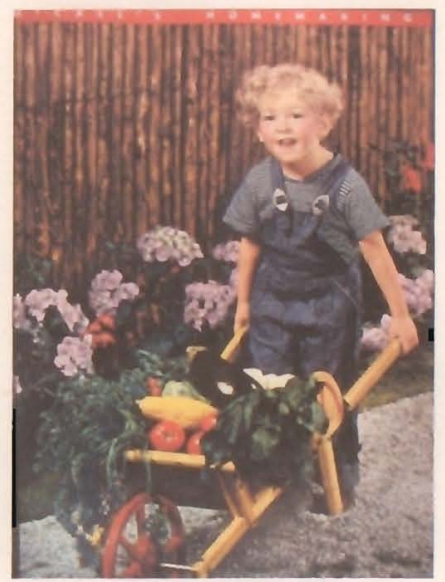

Homemaking

July 1937 


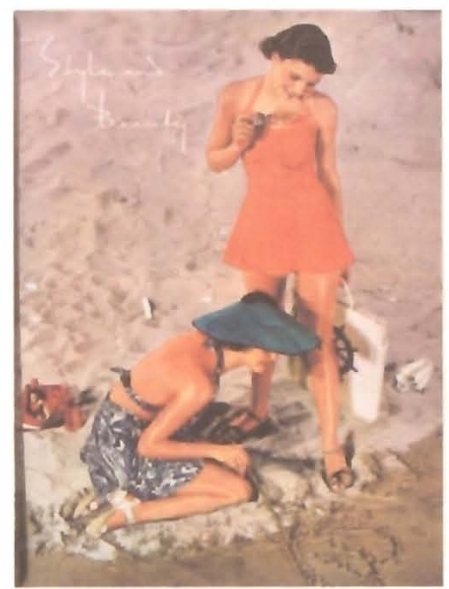

Style and Beauty July 1937

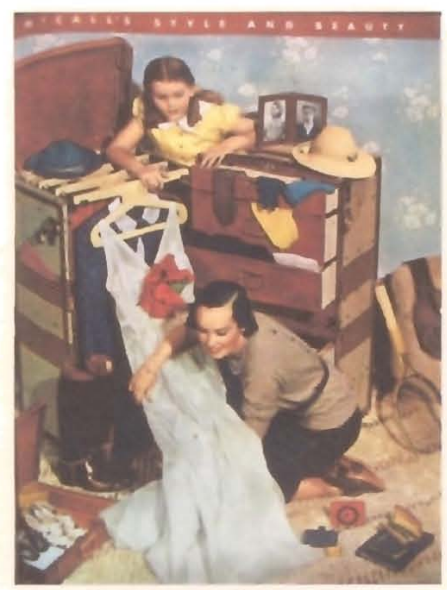

Style and Beauty

September 1937

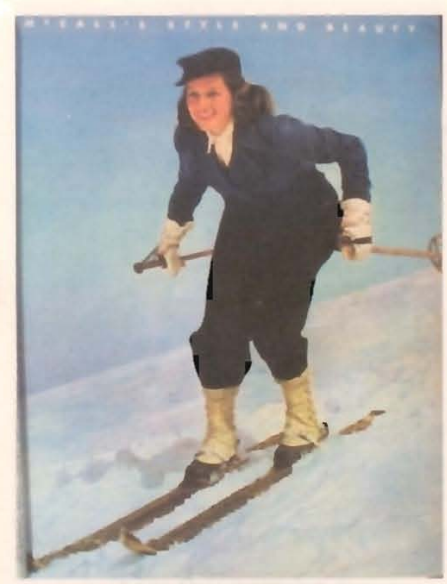

Style and Beauty January 1938

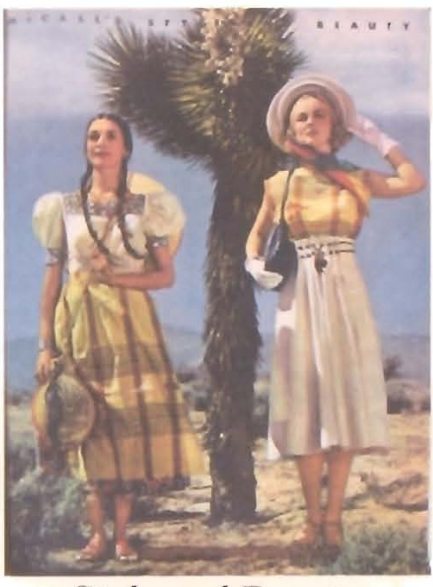

Style and Beauty

August 1937

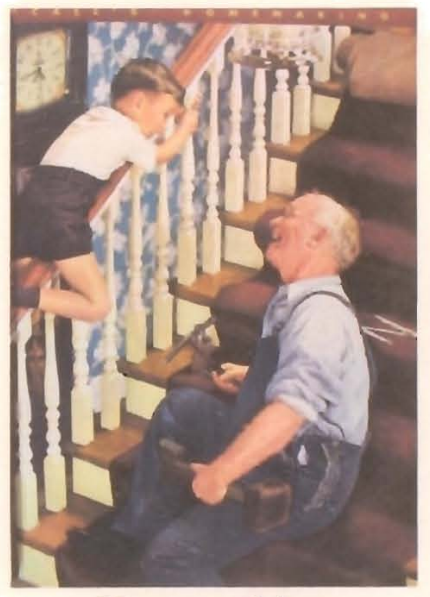

Homemaking

October 1937

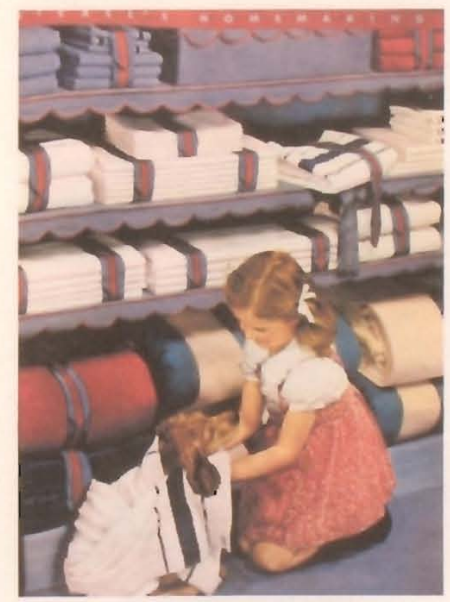

Homemaking February 1938

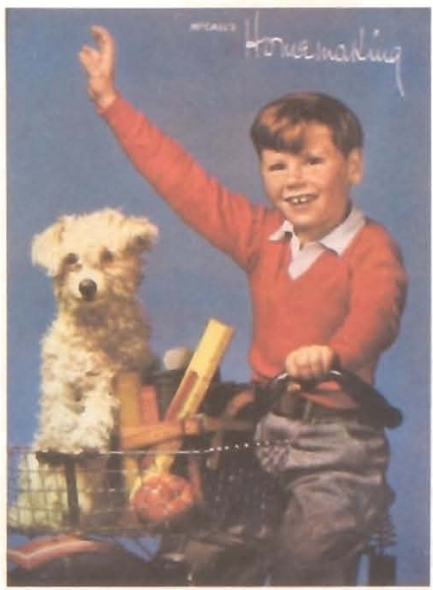

Homemaking

September 1937

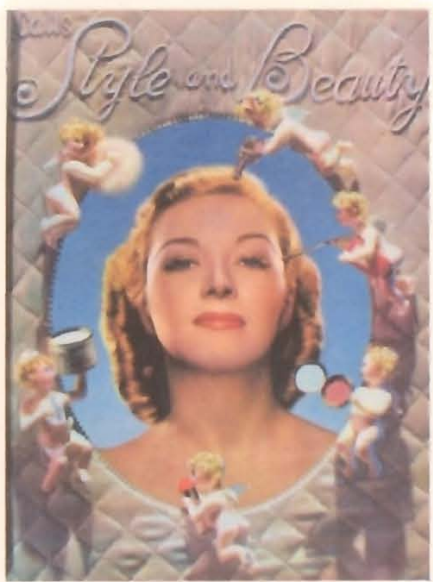

Style and Beauty

November 1938

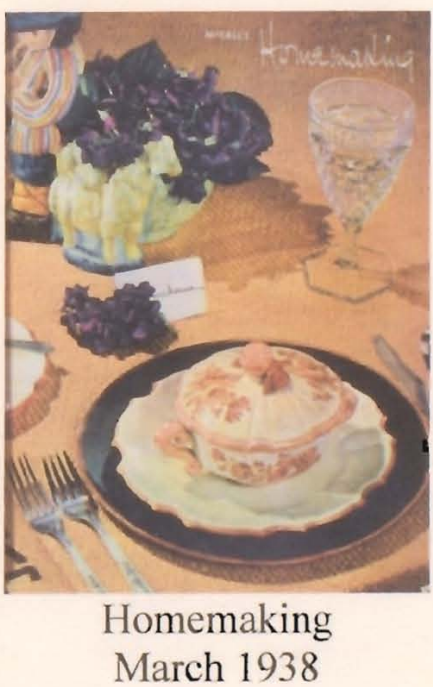




\section{8}

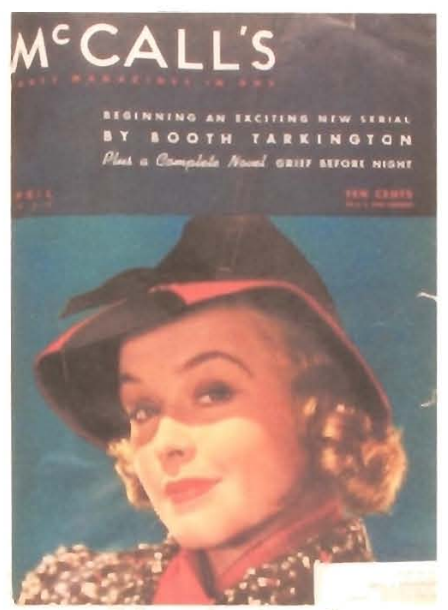

[frontispiece]

April 1938

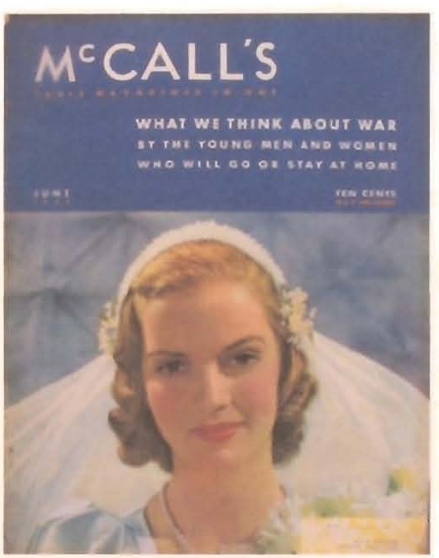

[fontispiece]

June 1938

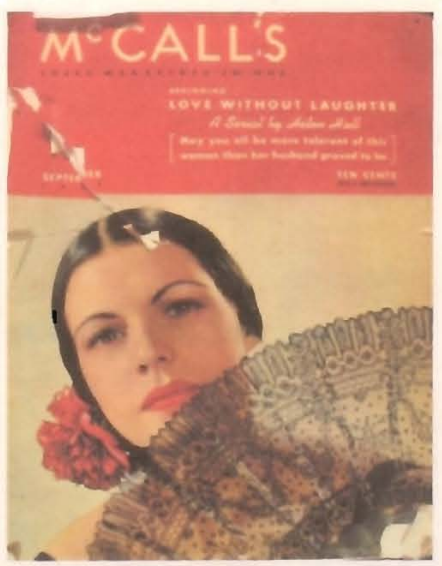

[frontispiece] September 1938

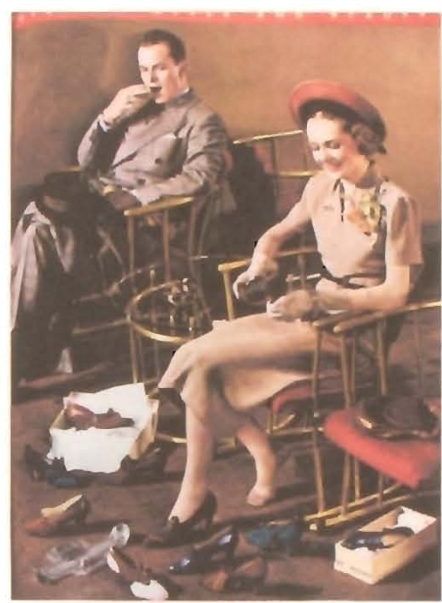

Style and Beauty April 1938

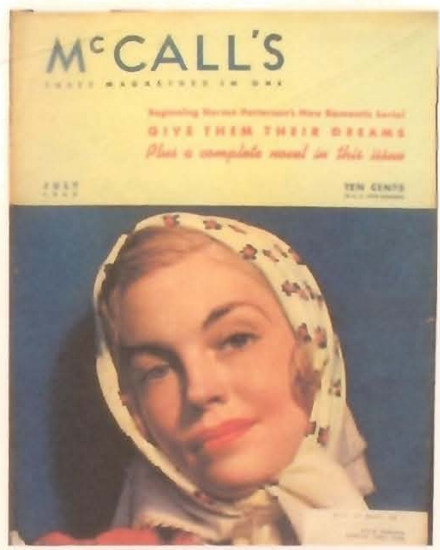

[frontispiece]

July 1938

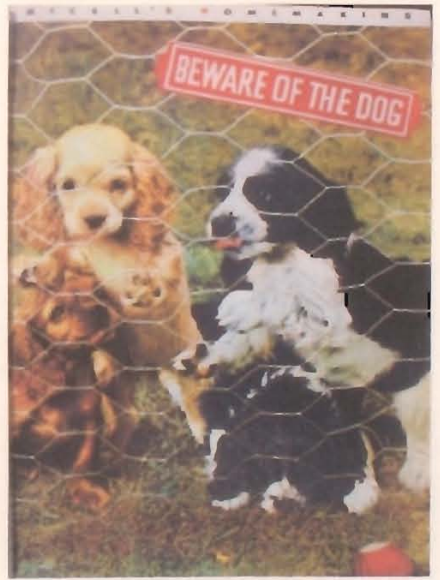

Homemaking

October 1938

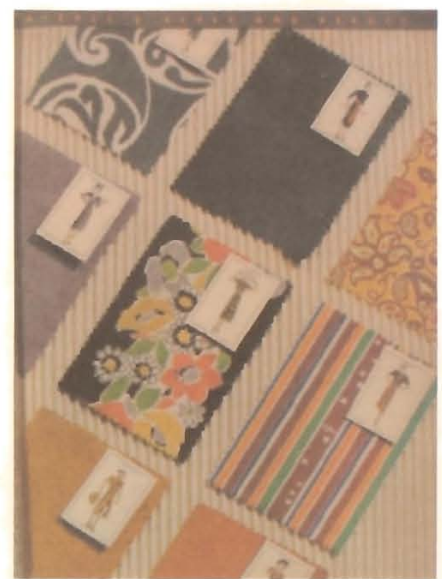

Style and Beauty May 1938

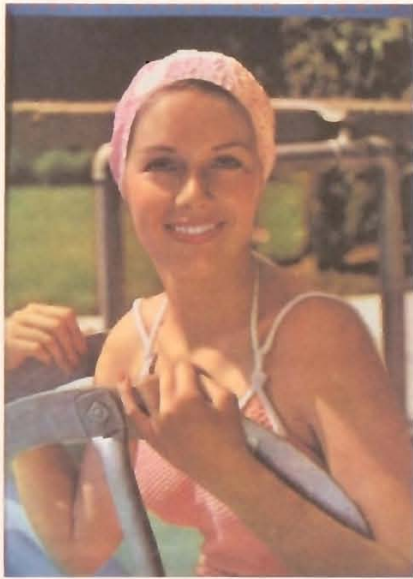

Style and Beauty July 1938

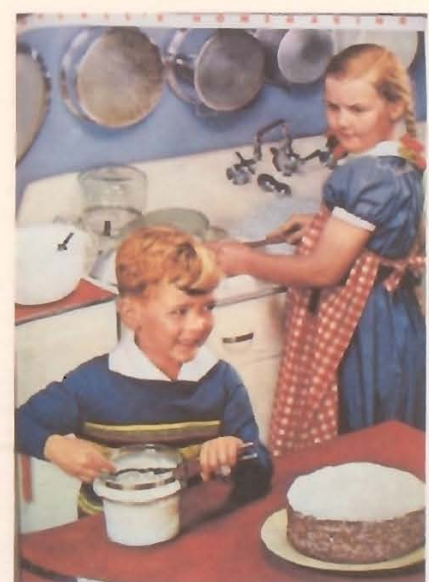

Homemaking October 1938 


\section{8-1939}

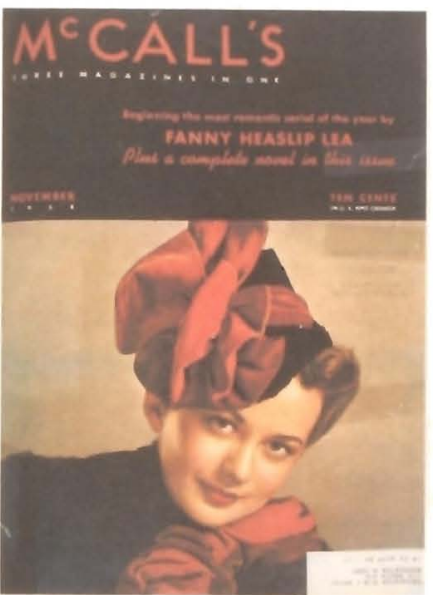

[frontispiece]

November 1938

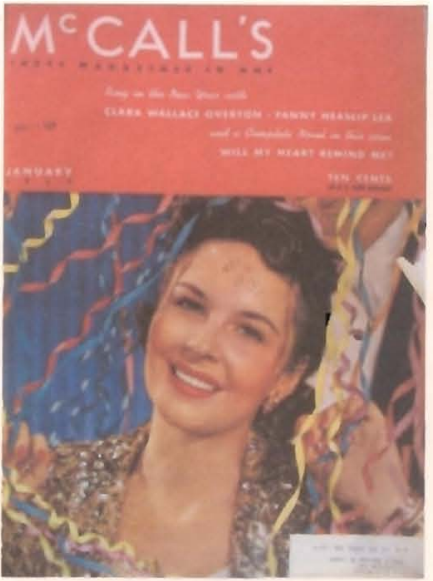

[frontispiece]

January 1939

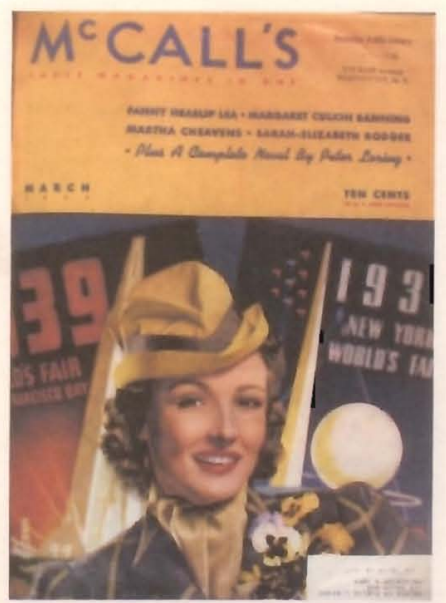

[frontispiece]

March 1939

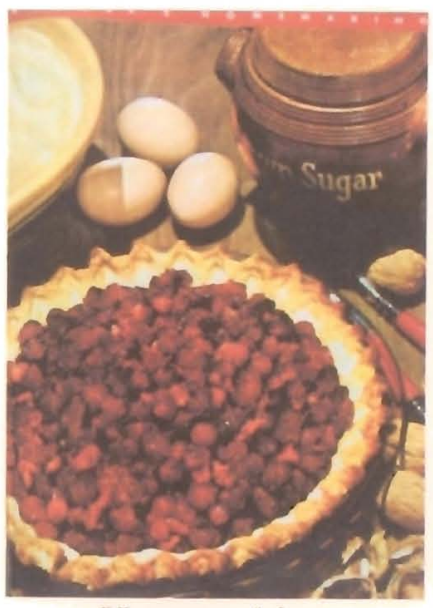

Homemaking

November 1938

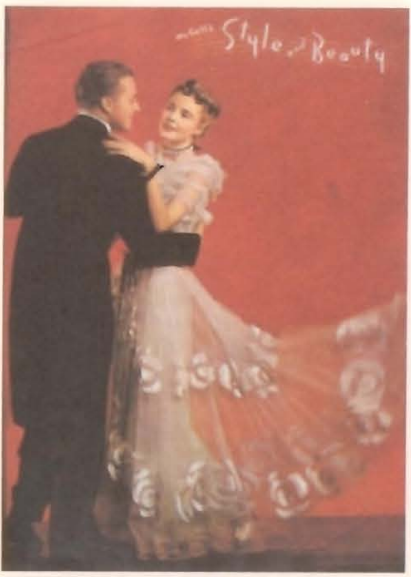

Style and Beauty January 1939

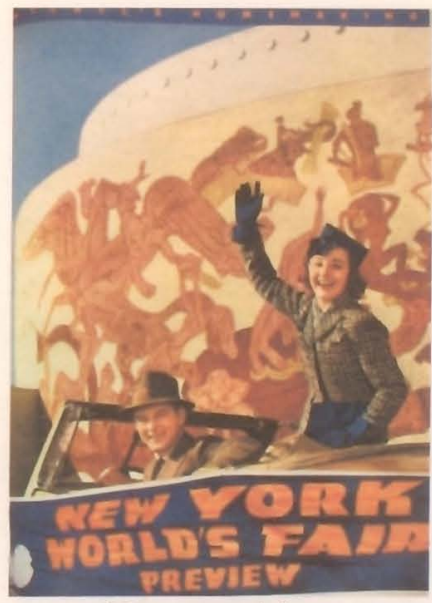

Homemaking March 1938

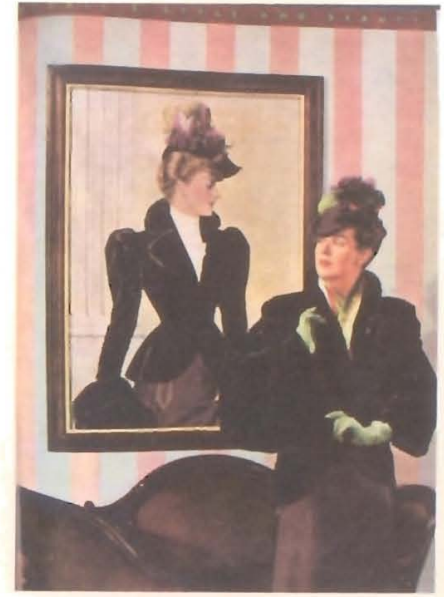

Style and Beauty

November 1938

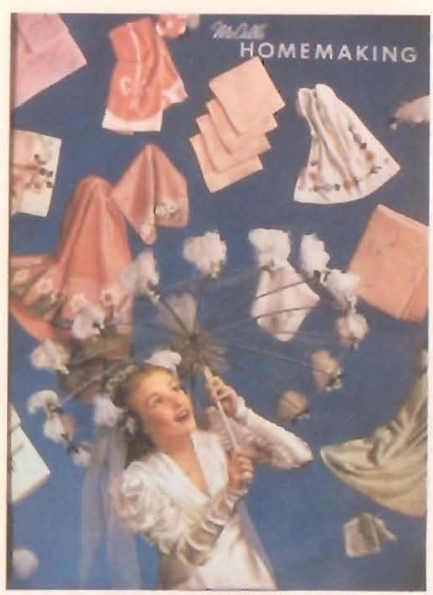

Homemaking

February 1939

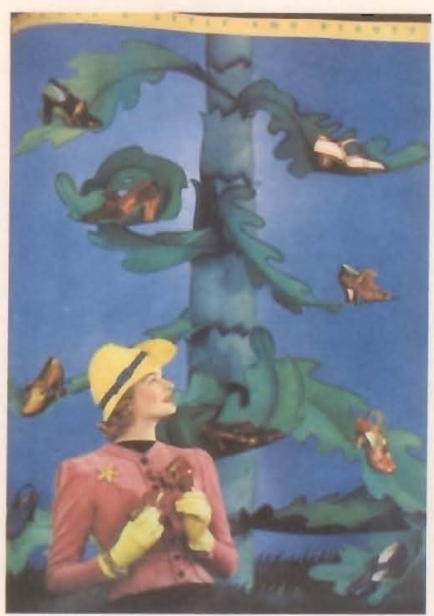

Style and Beauty

April 1939 


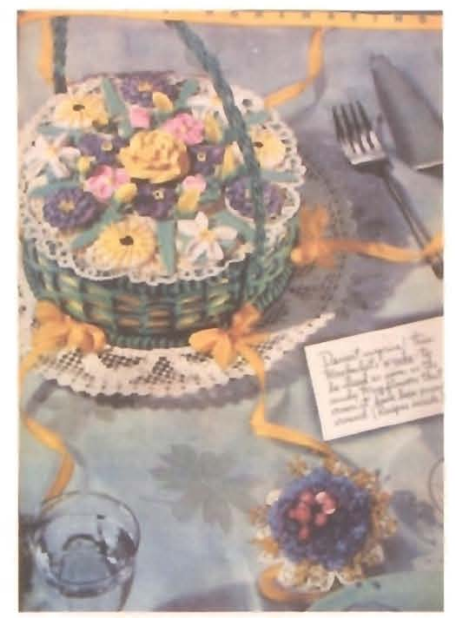

Homemaking May 1939

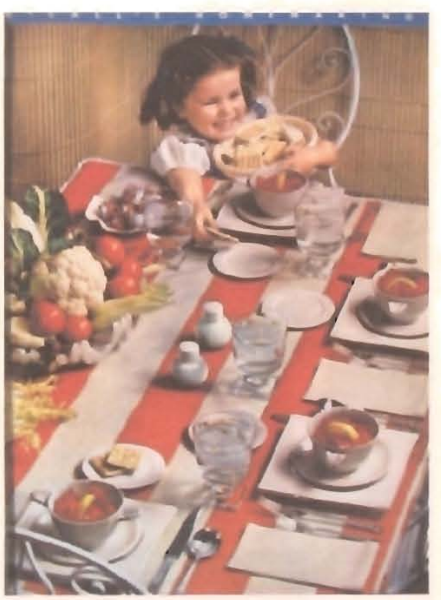

Homemaking July 1939

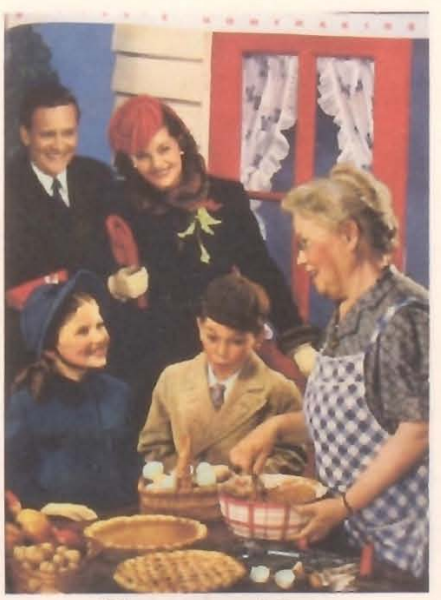

Homemaking

November 1939

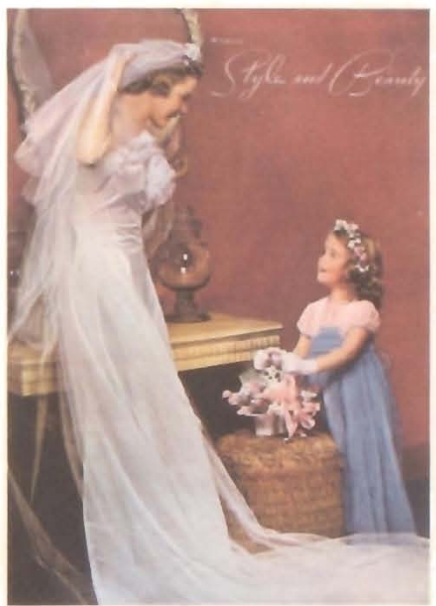

Style and Beauty June 1939

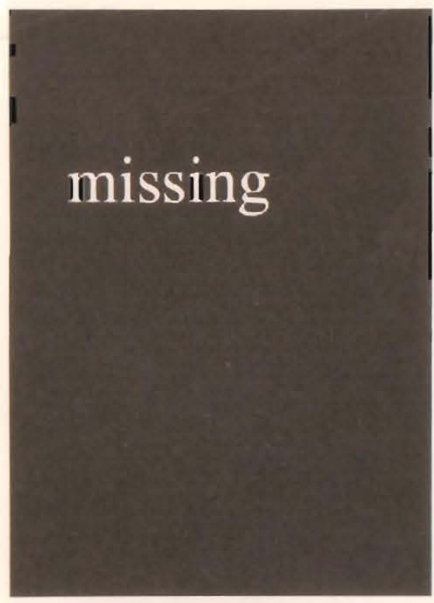

Style and Beauty July 1939

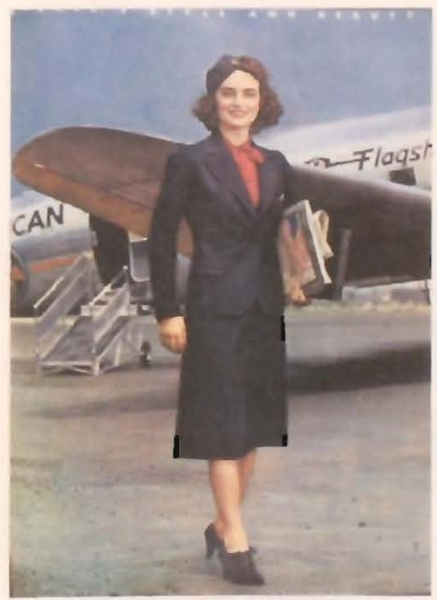

Style and Beauty

November 1939

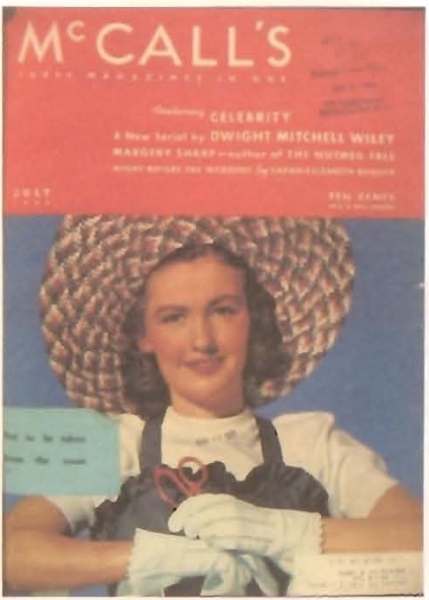

[frontispiece]

July 1939

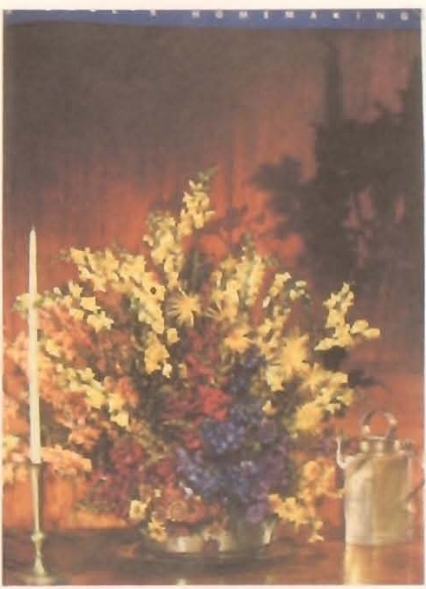

Homemaking

September 1939

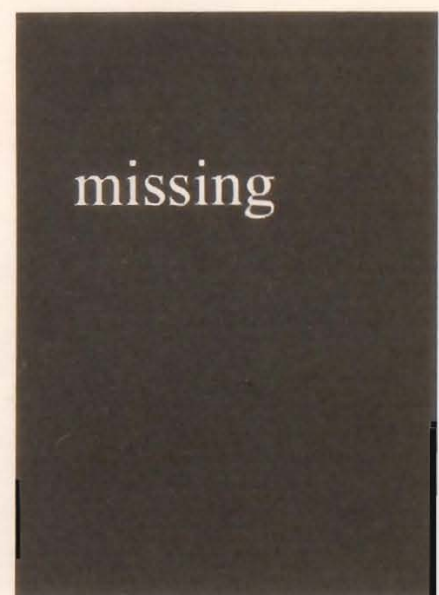

[frontispiece]

December 1939 


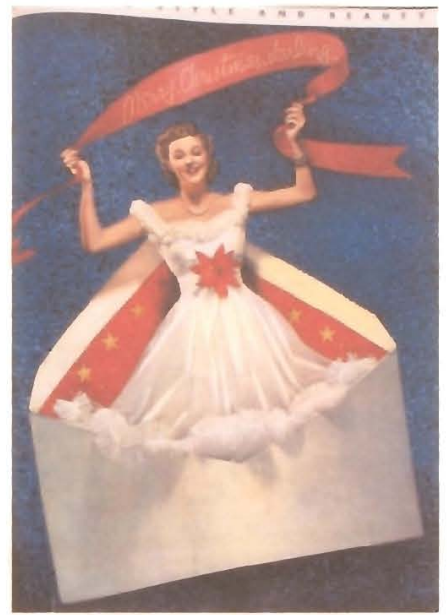

Style and Beauty

December 1939

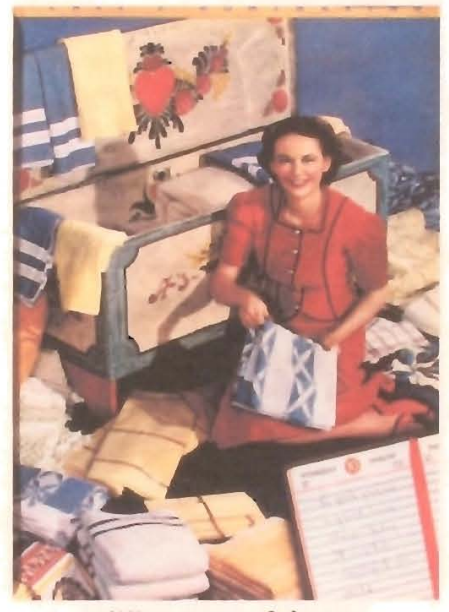

Homemaking February 1940

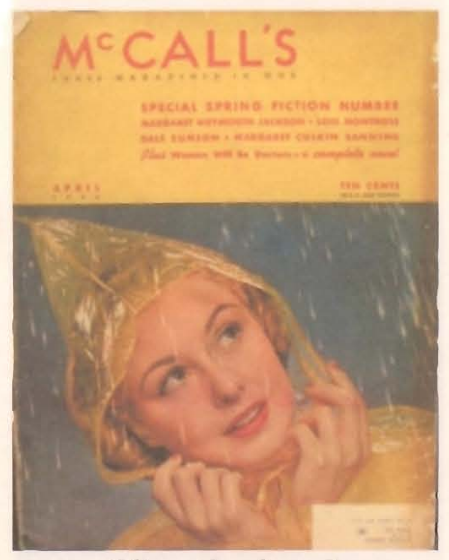

[frontispiece]

April 1940

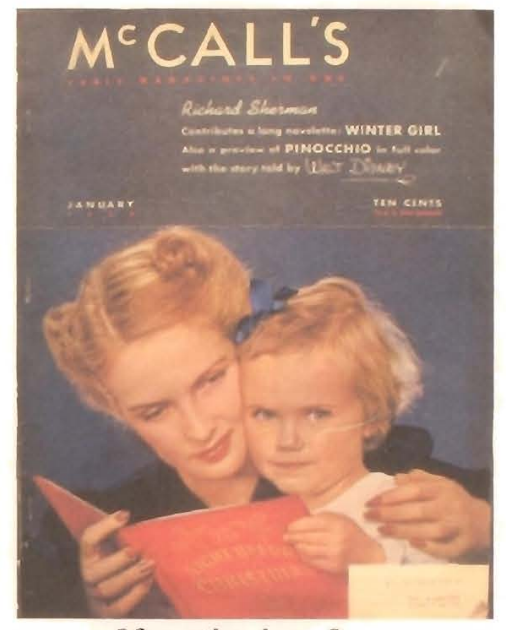

[frontispiece] January 1940

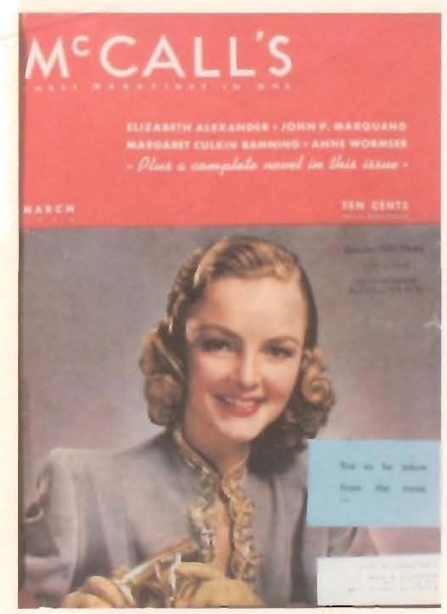

[frontispiece]

March 1940

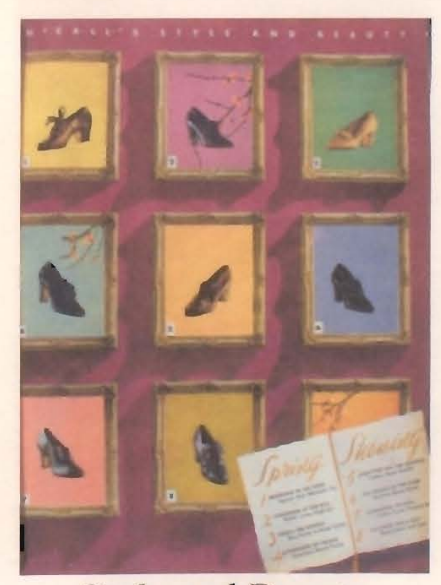

Style and Beauty

April 1940

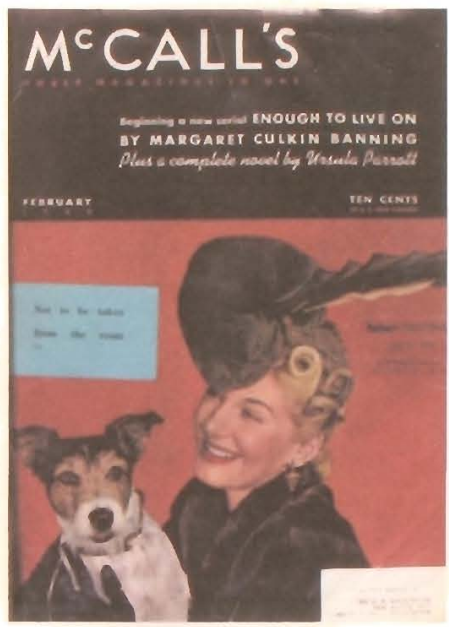

[frontispiece]

February 1940
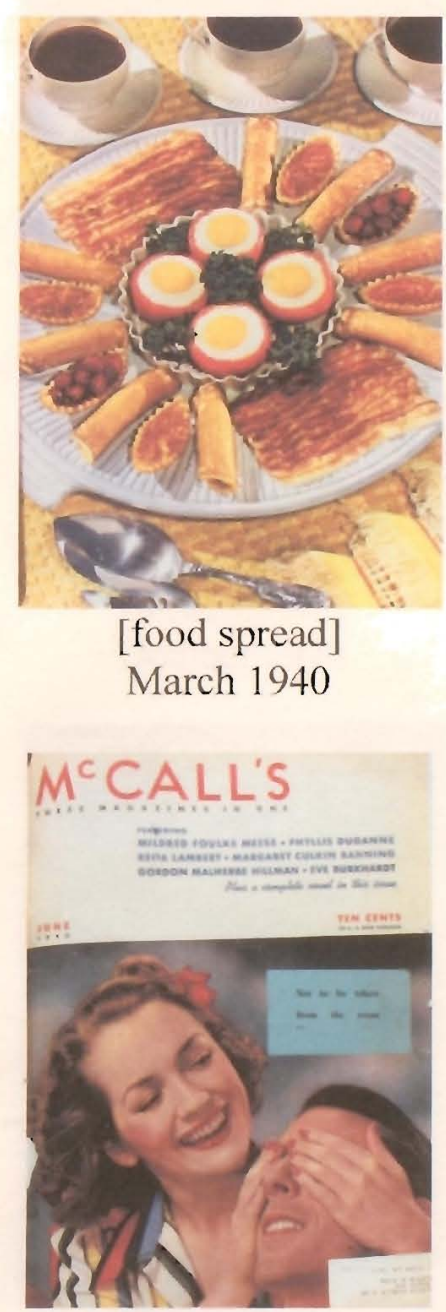

[frontispiece]

June 1940 


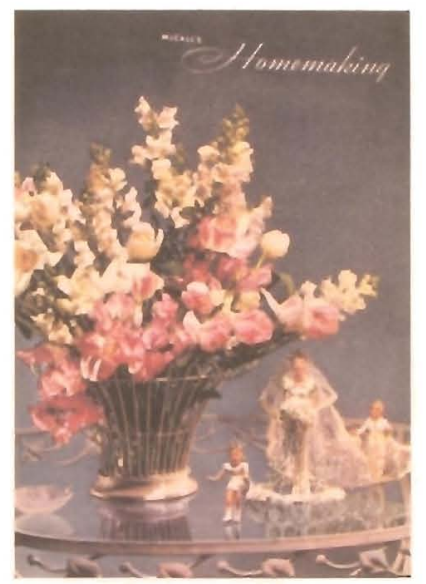

Homemaking June 1940

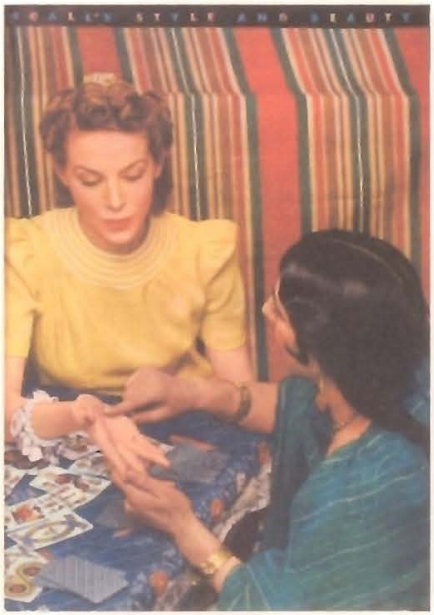

Style and Beauty August 1940

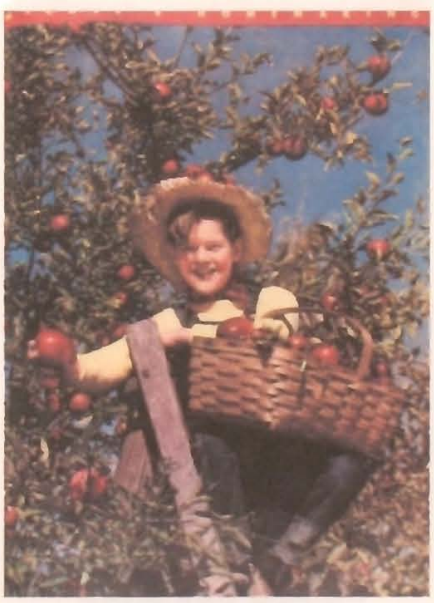

Homemaking October 1940

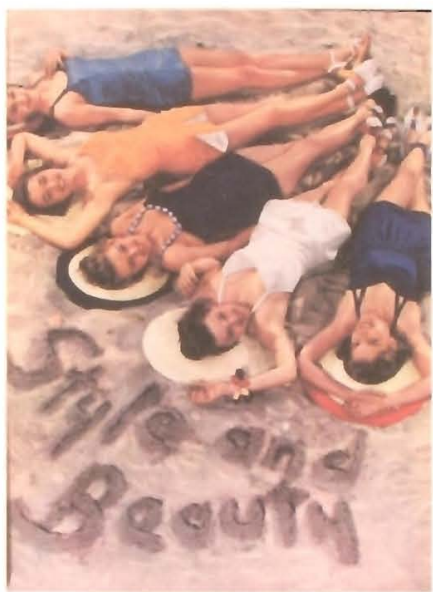

Style and Beauty July 1940

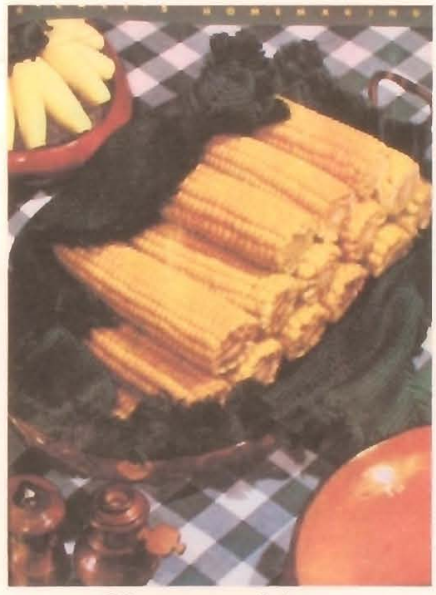

Homemaking

September 1940

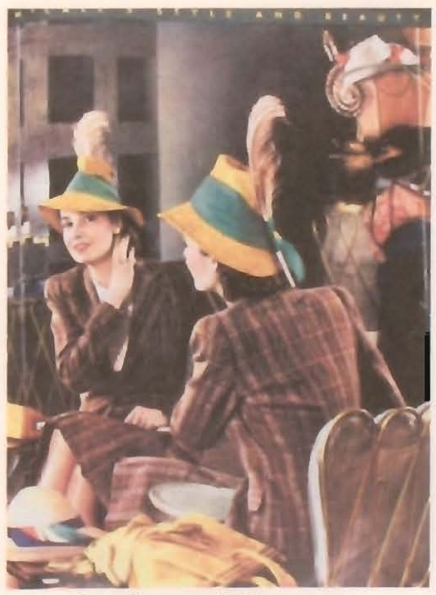

Style and Beauty October 1940

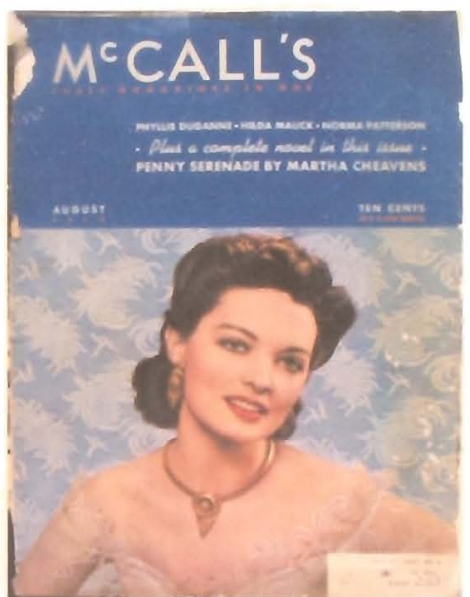

[frontispiece]

August 1940

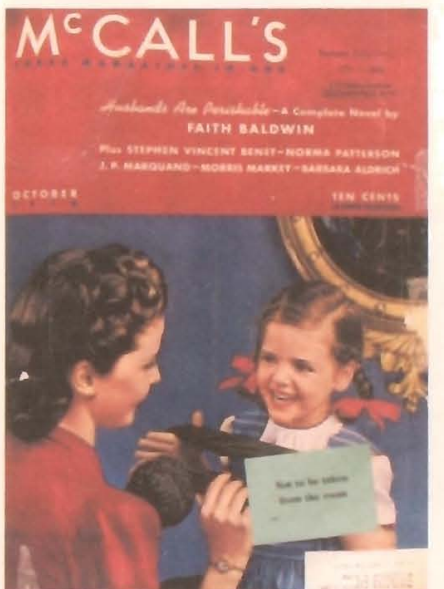

[frontispiece]

October 1940

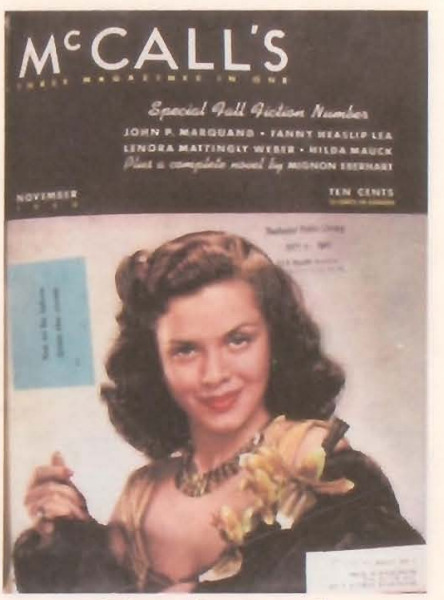

[frontispiece]

November 1940 


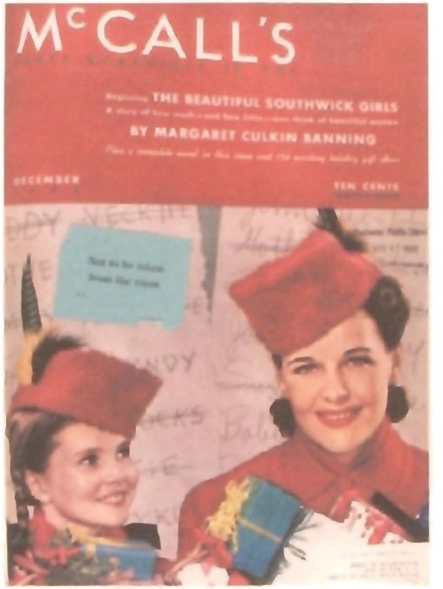

[frontispiece]

December 1940

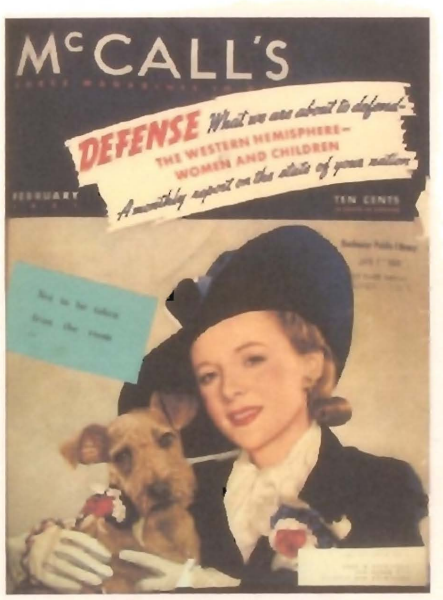

[frontispiece]

February 1941

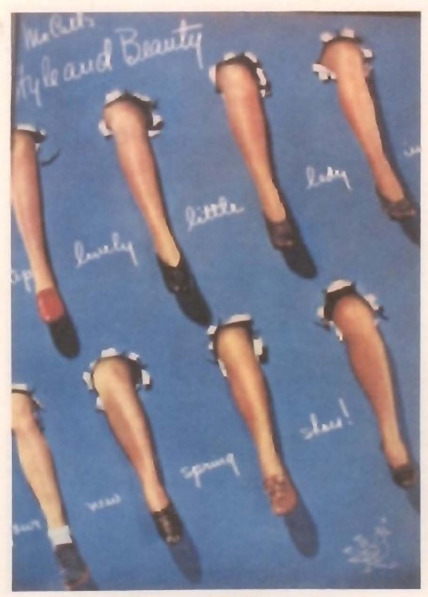

Style and Beauty April 1941

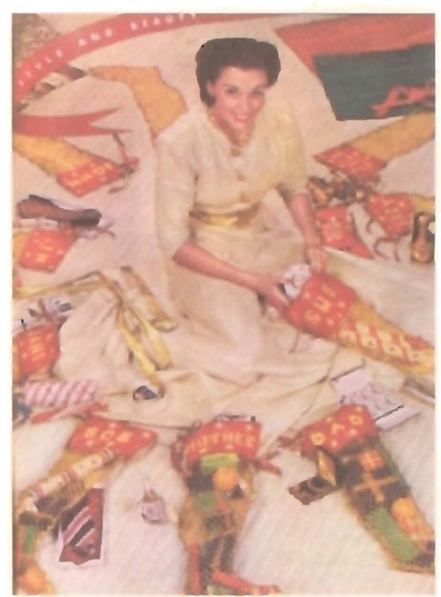

Style and Beauty

December 1940

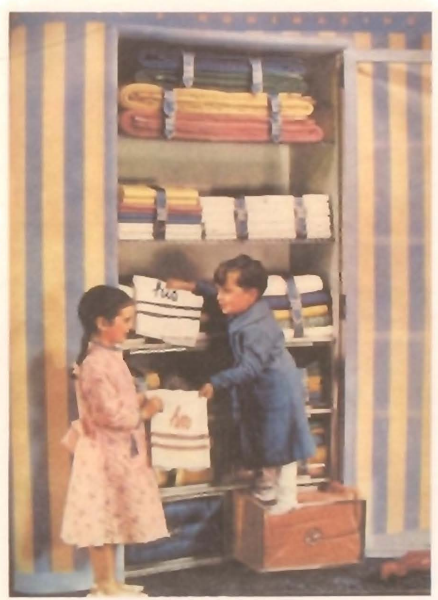

Homemaking

February 1941

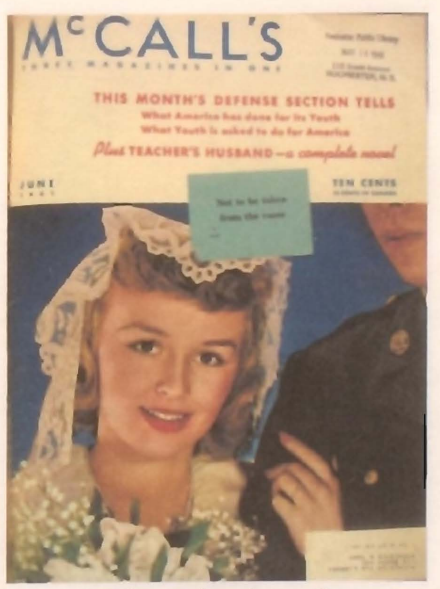

[frontispiece]

June 1941

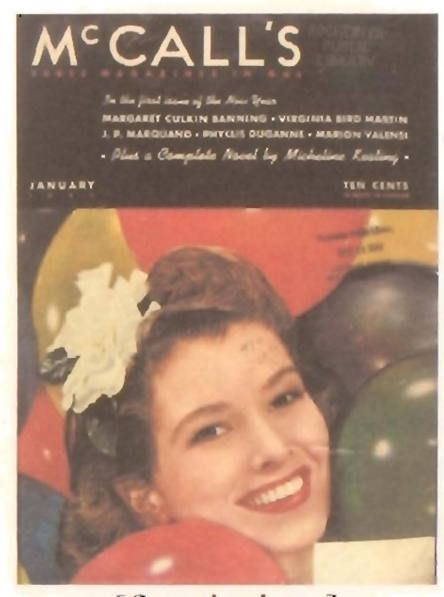

[frontispiece] January 1941

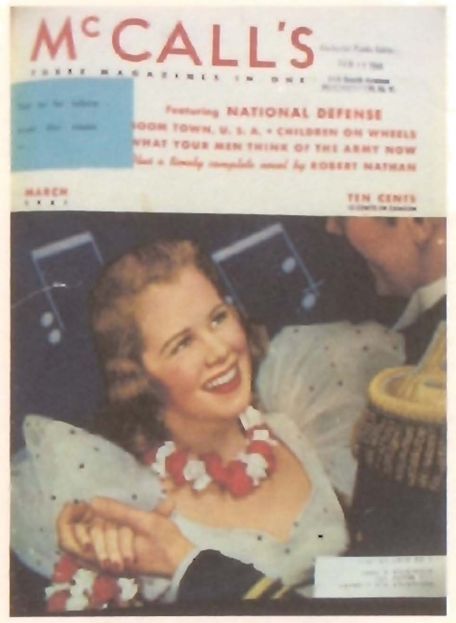

[frontispiece]

March 1941

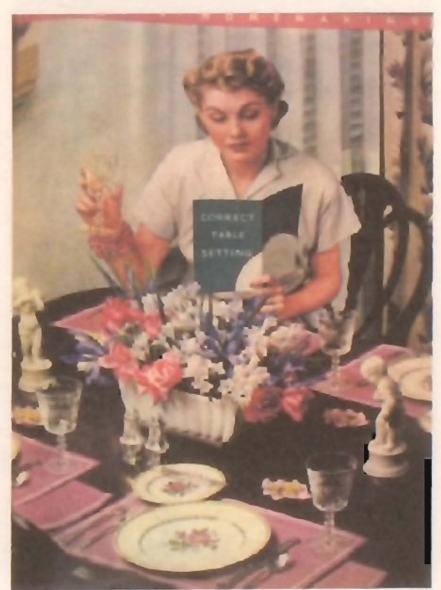

Homemaking

June 1941 


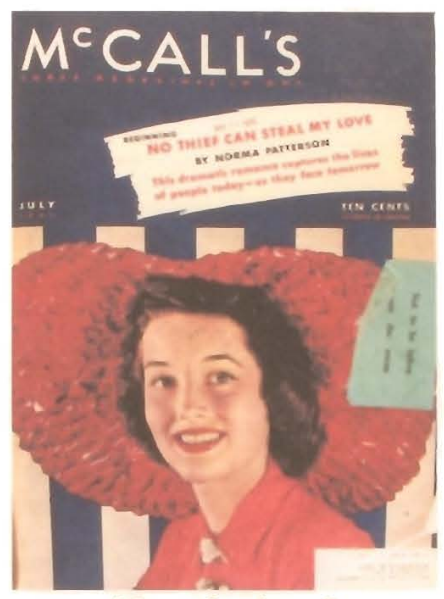

[frontispiece] July 1941

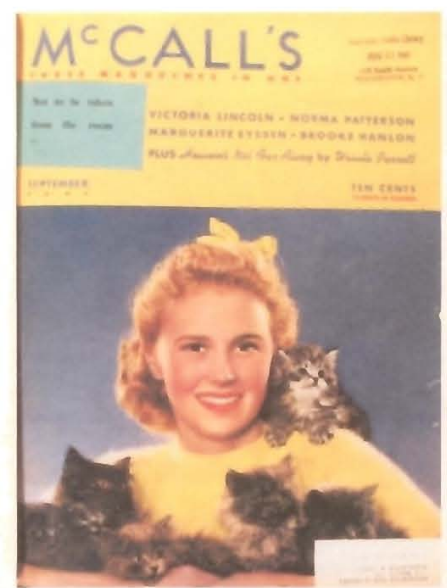

[frontispiece]

September 1941

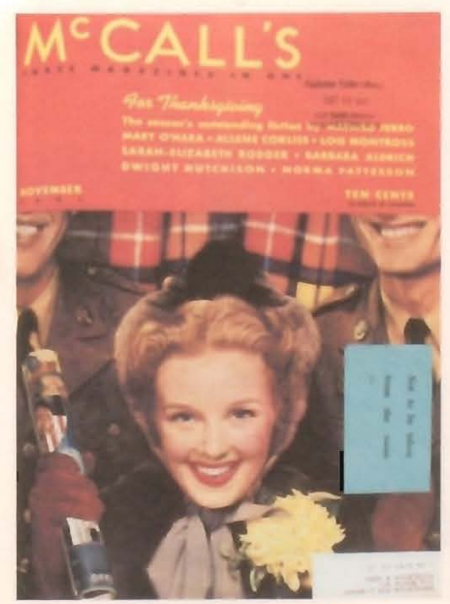

[frontispiece]

November 1941

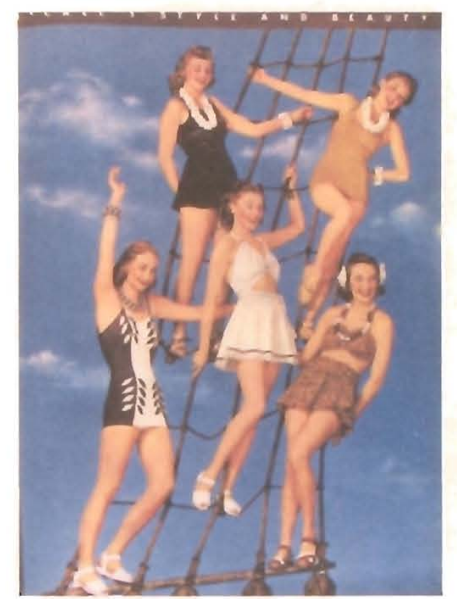

Style and Beauty July 1941

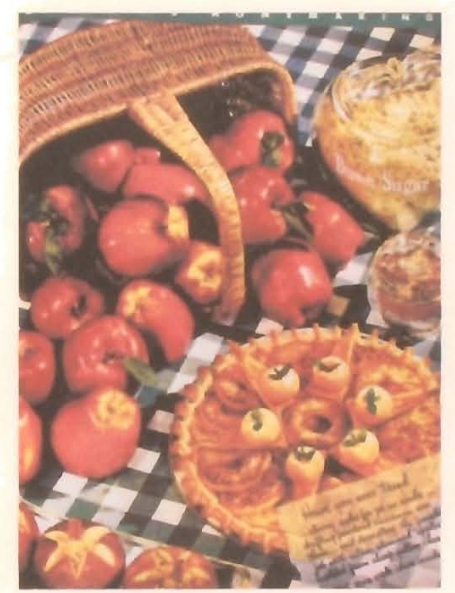

Homemaking

September 1941

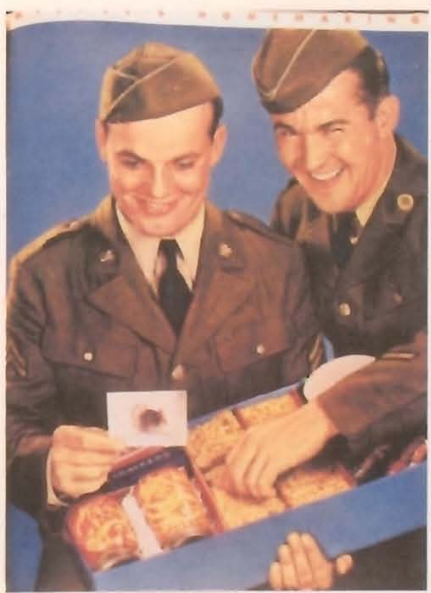

Homemaking

November 1941

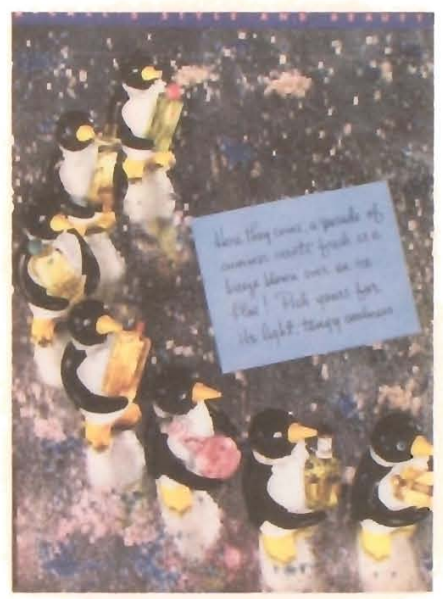

Style and Beauty

August 1941

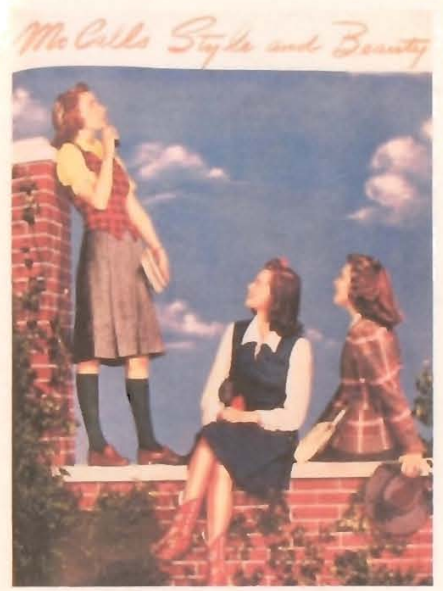

Style and Beauty

September 1941

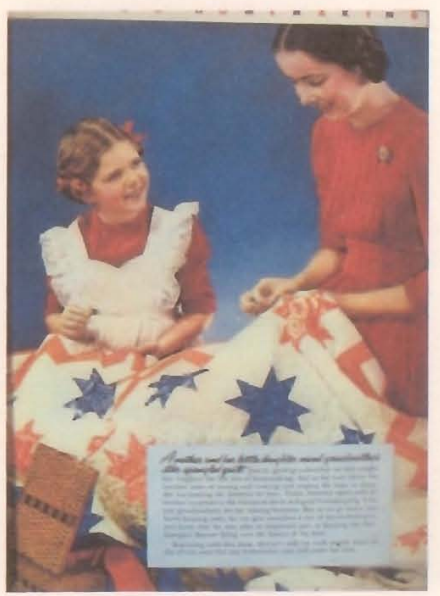

Homemaking January 1942 


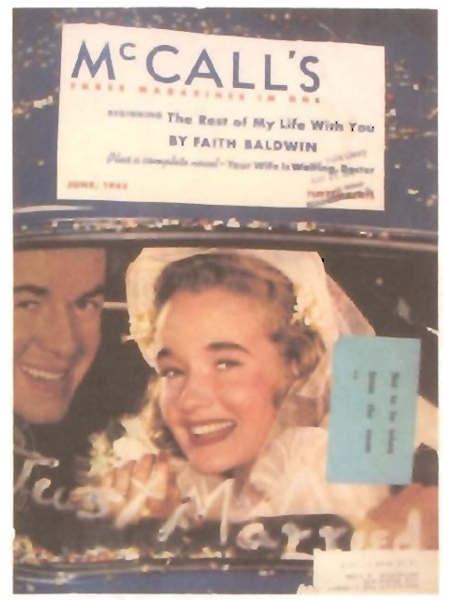

[frontispiece] June 1942

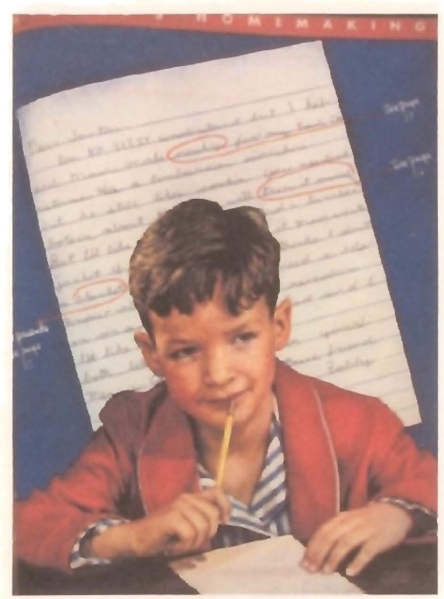

Homemaking December 1942

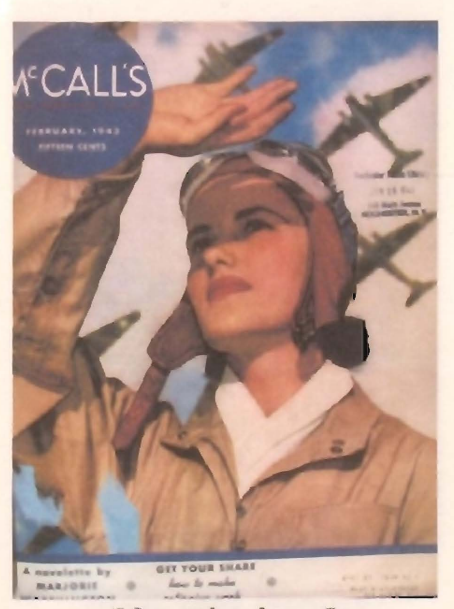

[frontispiece] February 1943

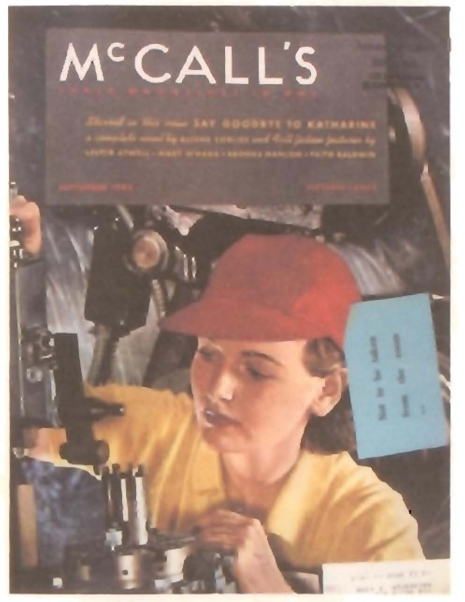

[frontispiece]

September 1942

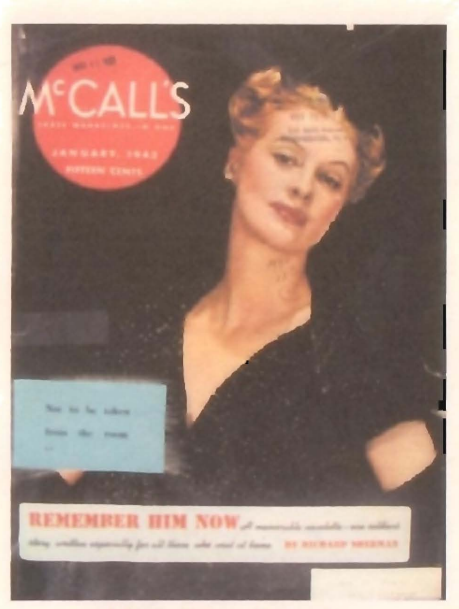

[frontispiece] January 1943

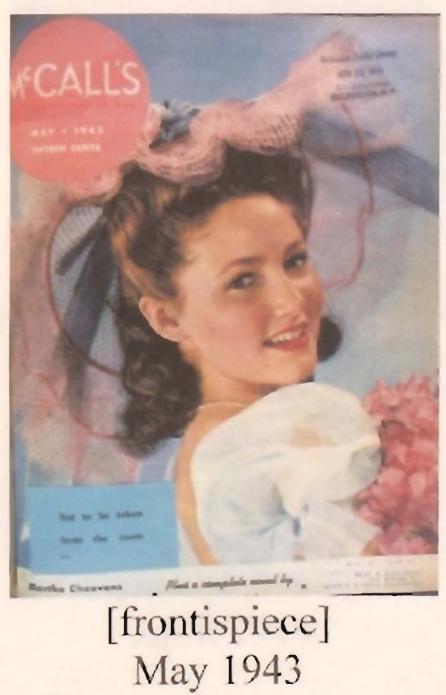

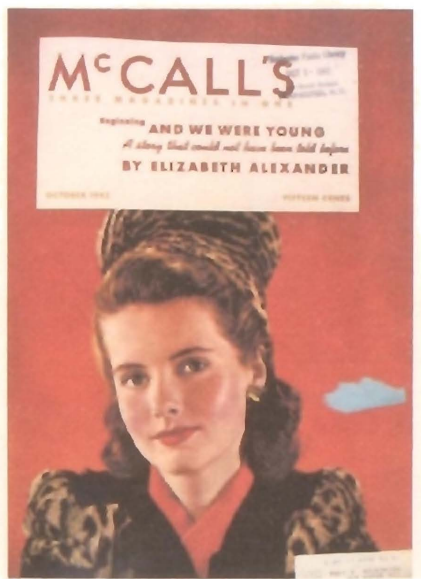

[frontispiece]

October 1942

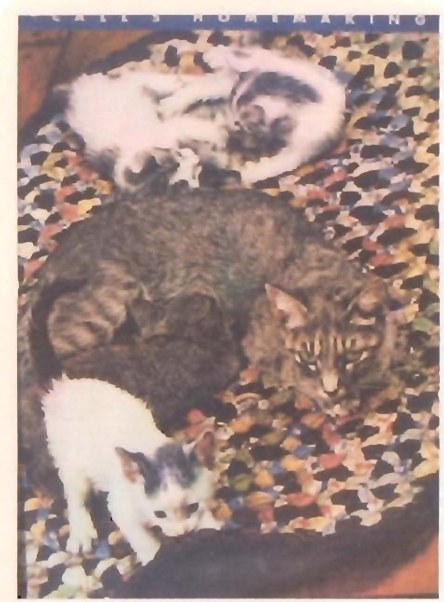

Homemaking January 1941

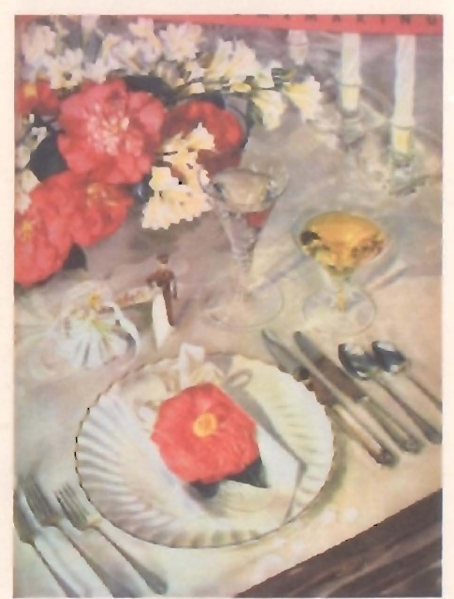

Homemaking June 1943 


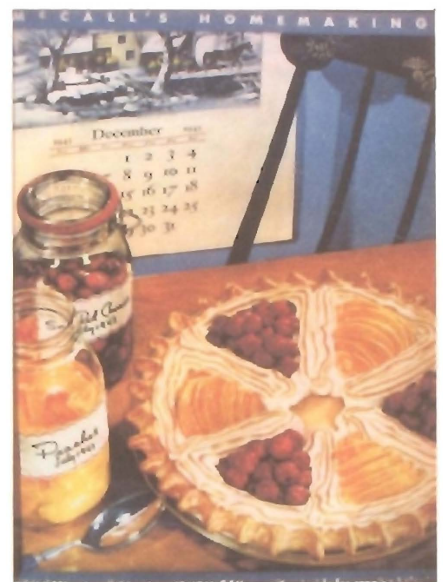

Homemaking

July 1943

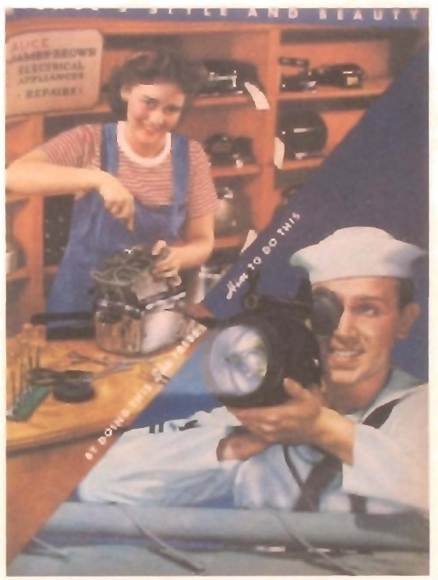

Ruzzi Green and Muray

Style and Beauty

September 1943

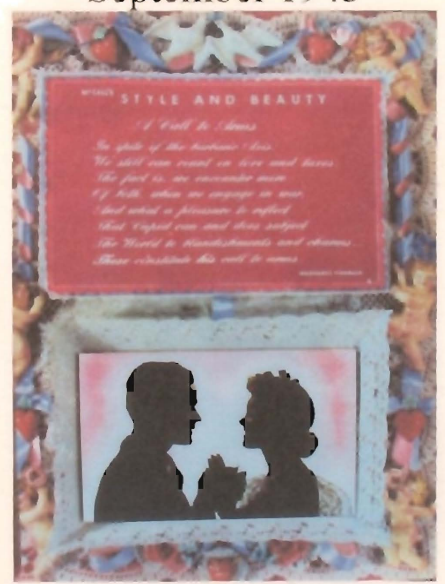

Style and Beauty

February 1944

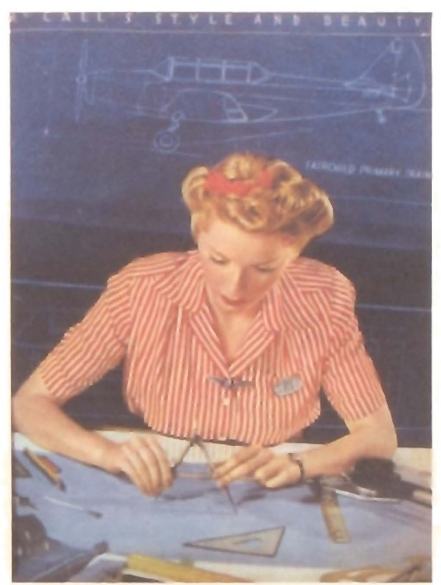

Style and Beauty July 1943

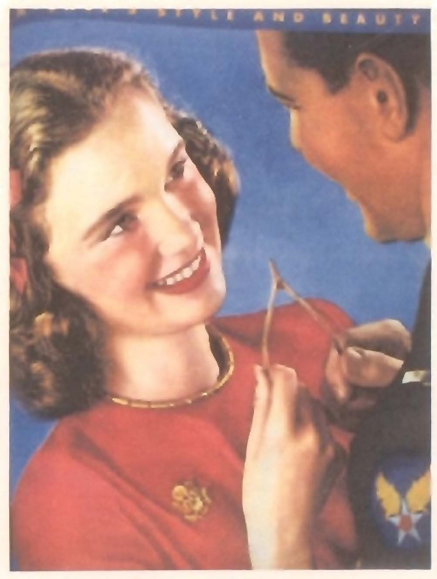

Style and Beauty

November 1943

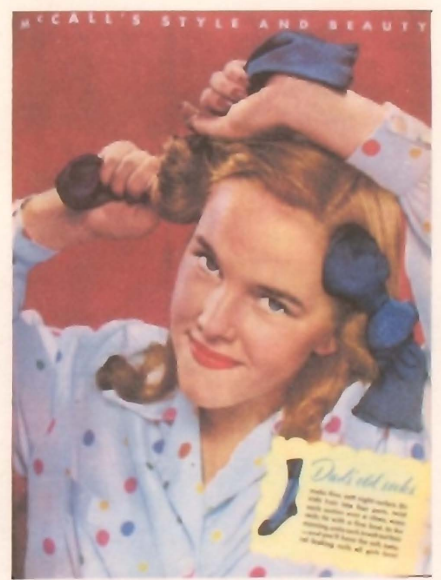

Style and Beauty April 1944

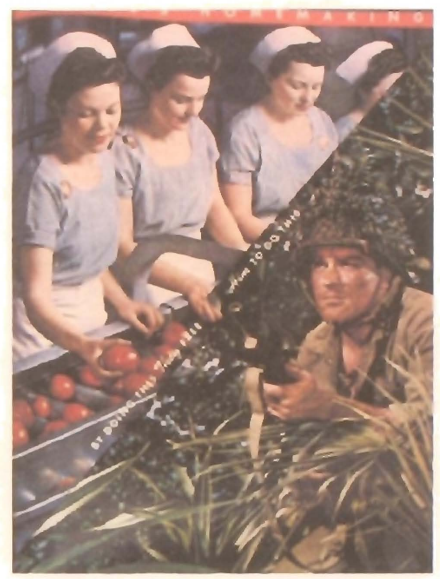

Ruzzi Green and Muray Homemaking

September 1943
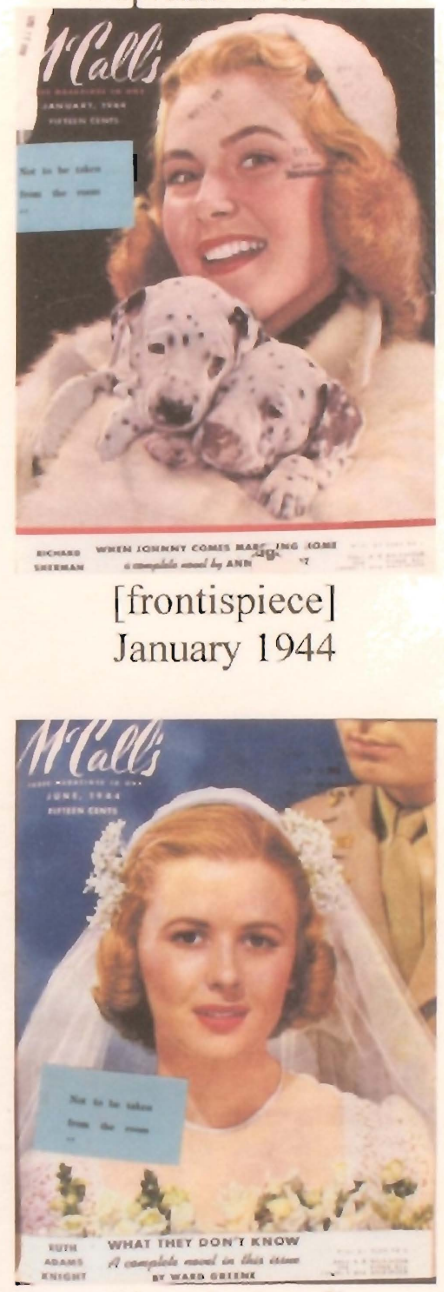

[frontispiece]

June 1944 
1944-1945

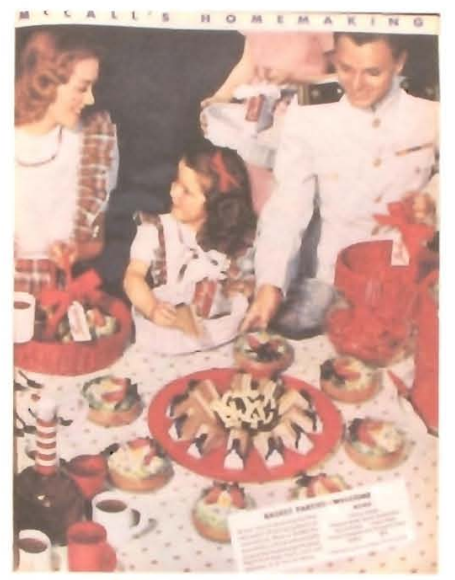

Homemaking August 1944

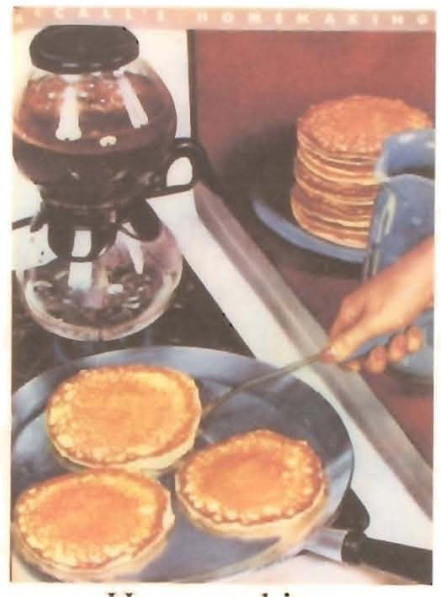

Homemaking October 1944

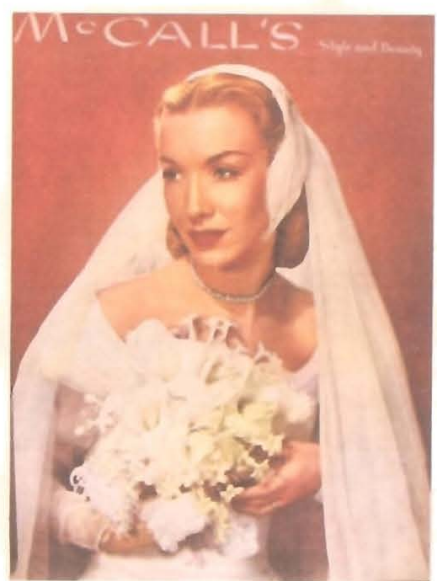

Style and Beauty January 1945 
Appendix

Nickolas Muray Carbro Prints for 'McCall's' at

George Eastman House International Museum of

Photography and Film, 1933-1945

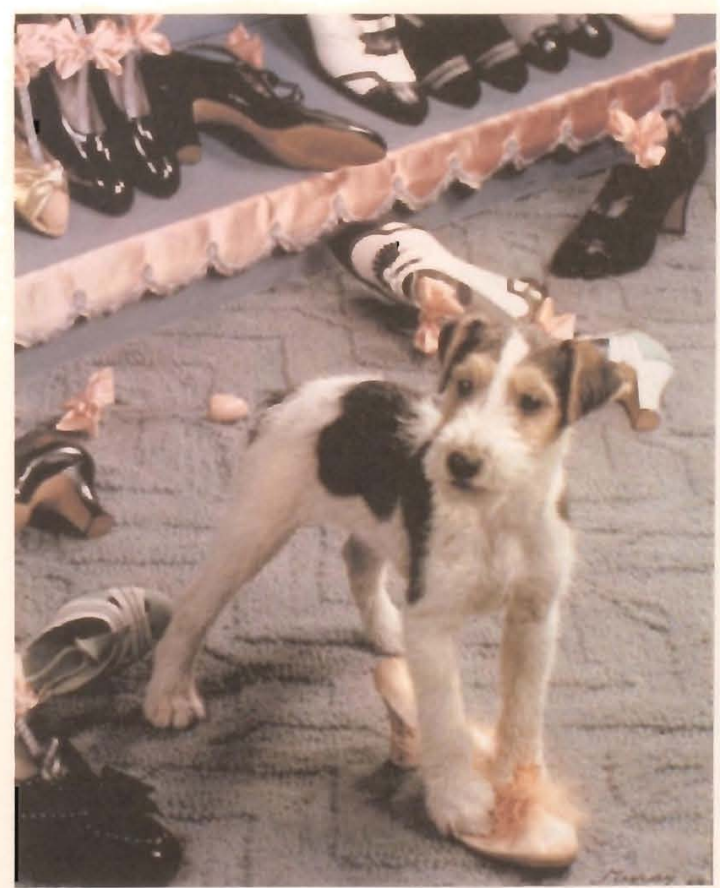

Style and Beauty

Published April 1936

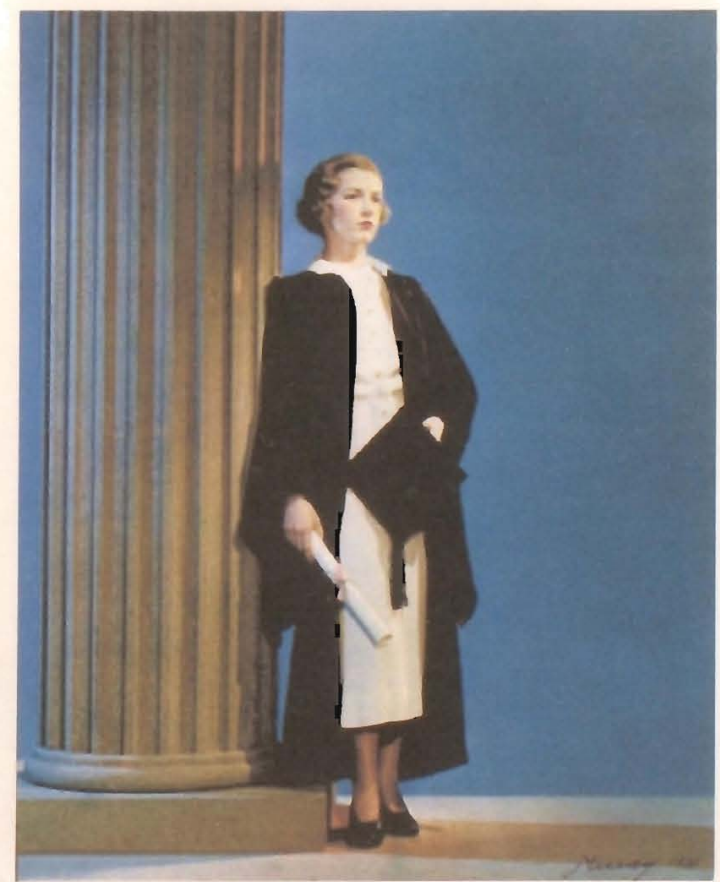

Style and Beauty

Published June 1936 


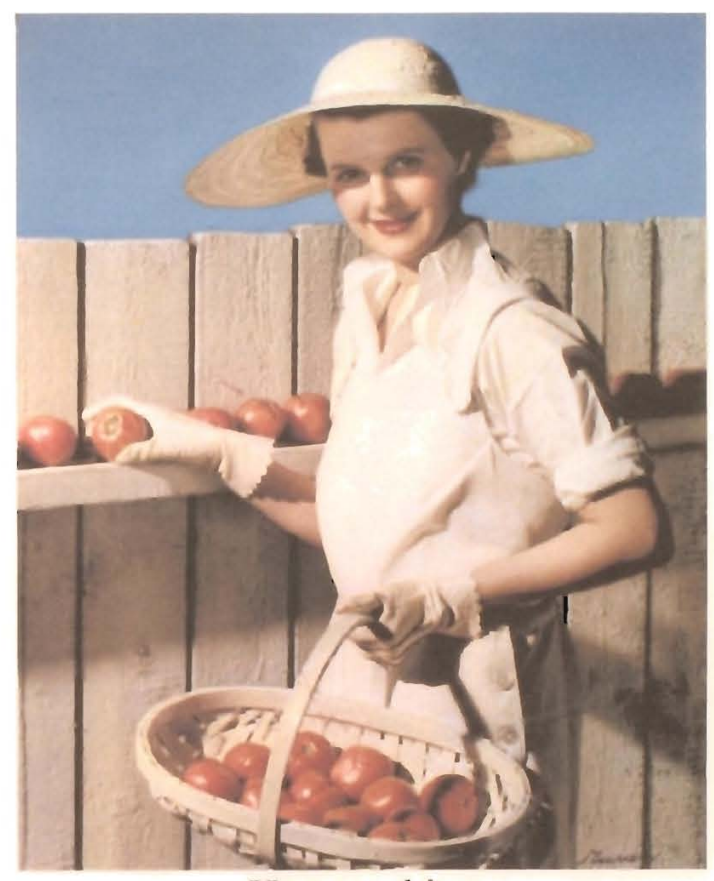

Homemaking

Published August 1936

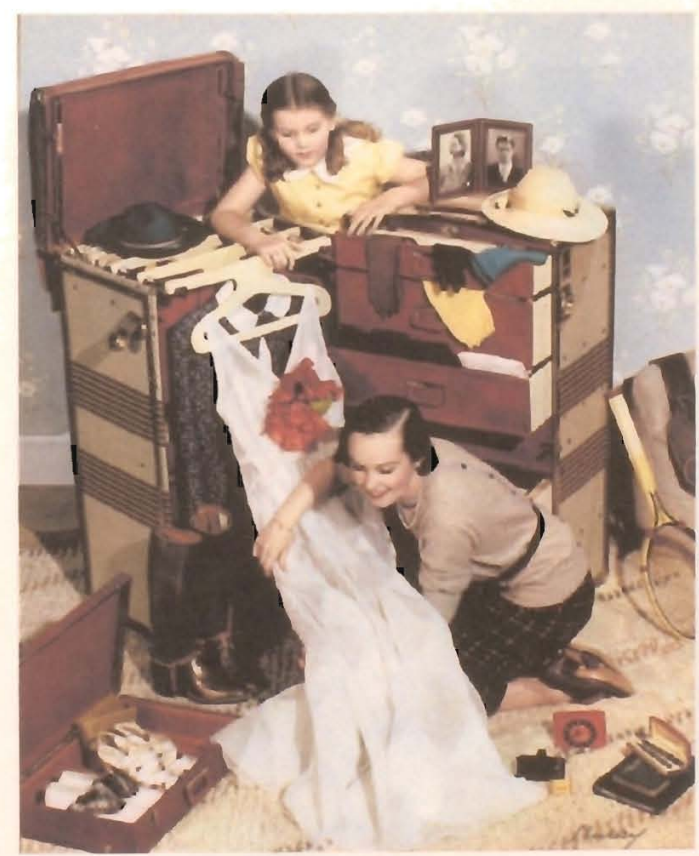

Style and Beauty

Published September 1937

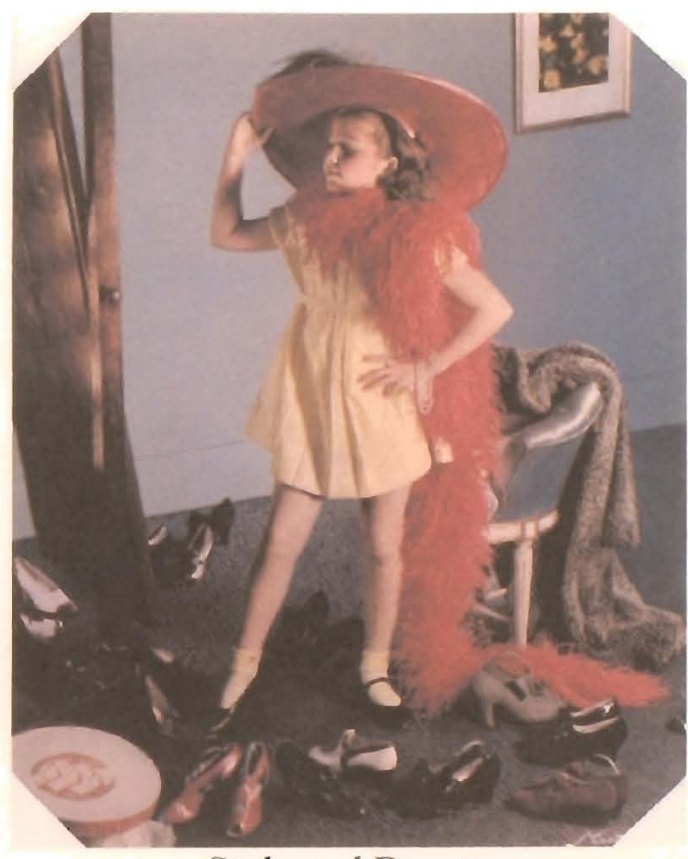

Style and Beauty

Published September 1937

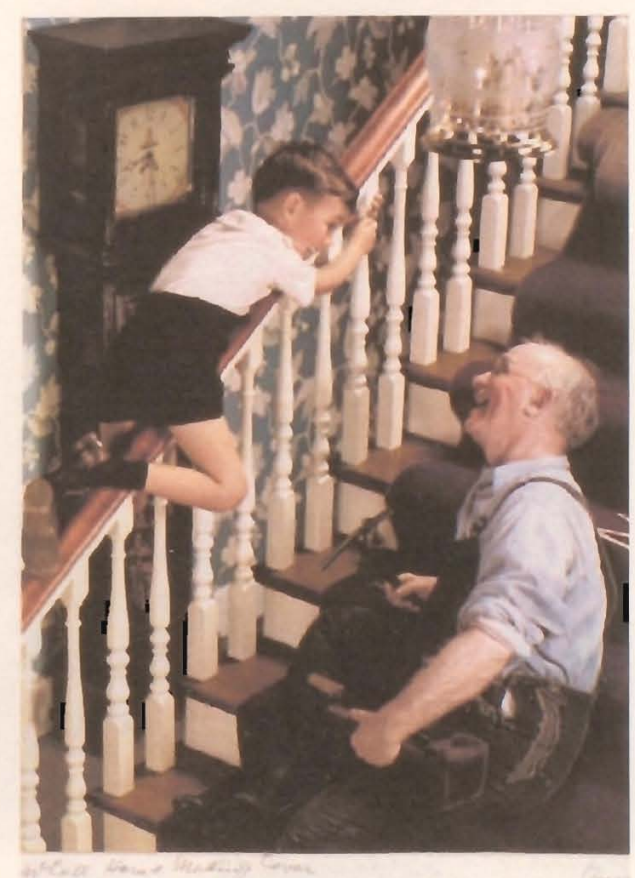

Homemaking

Published October 1937 

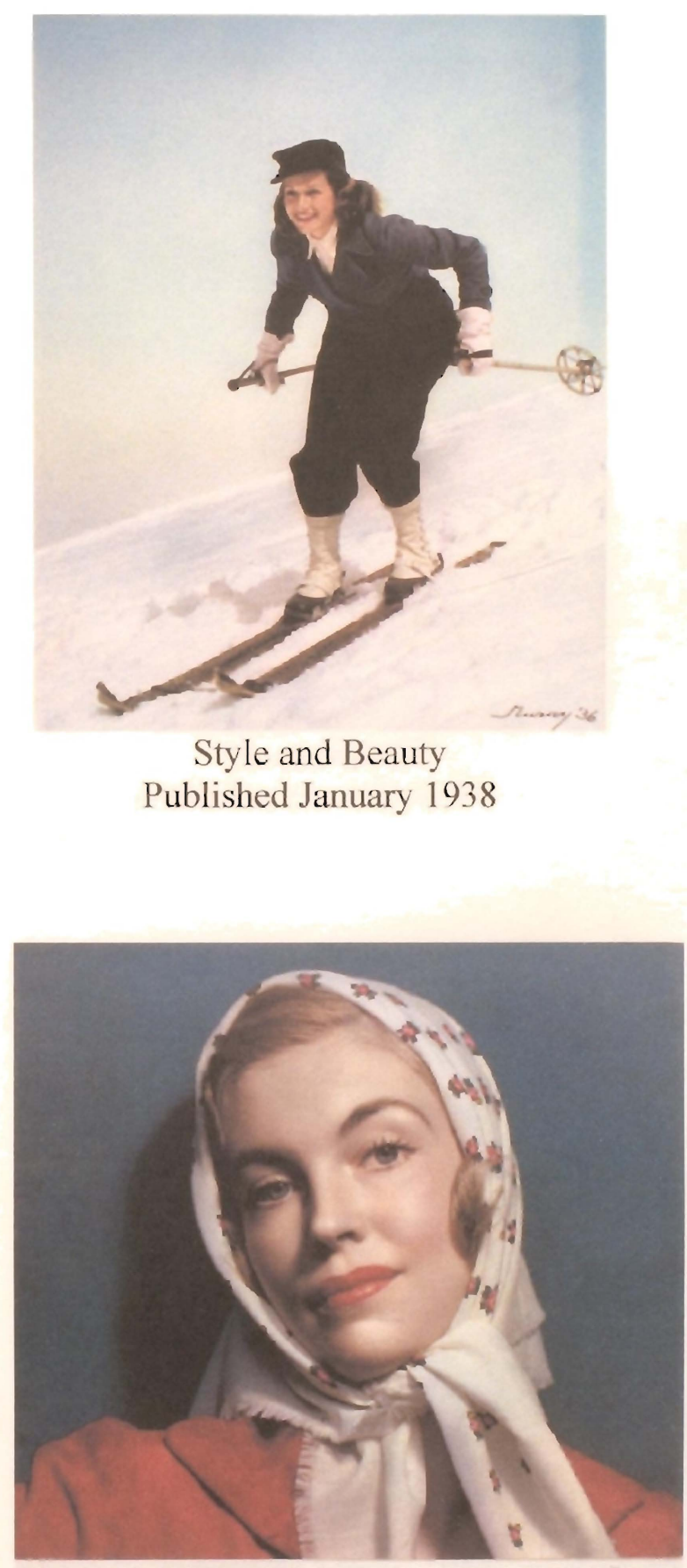

[frontispiece]

Published July 1938

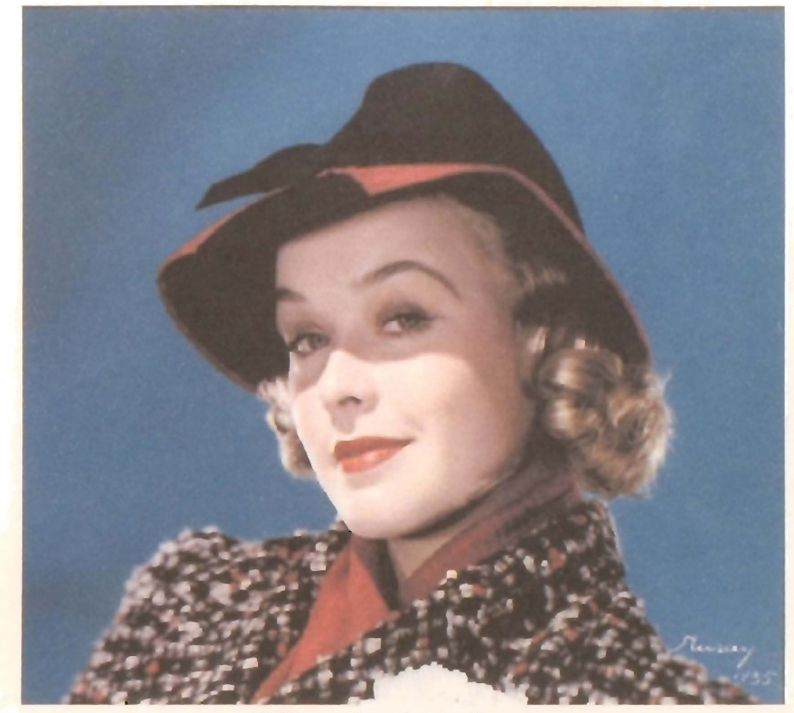

[frontispiece]

Published April 1938

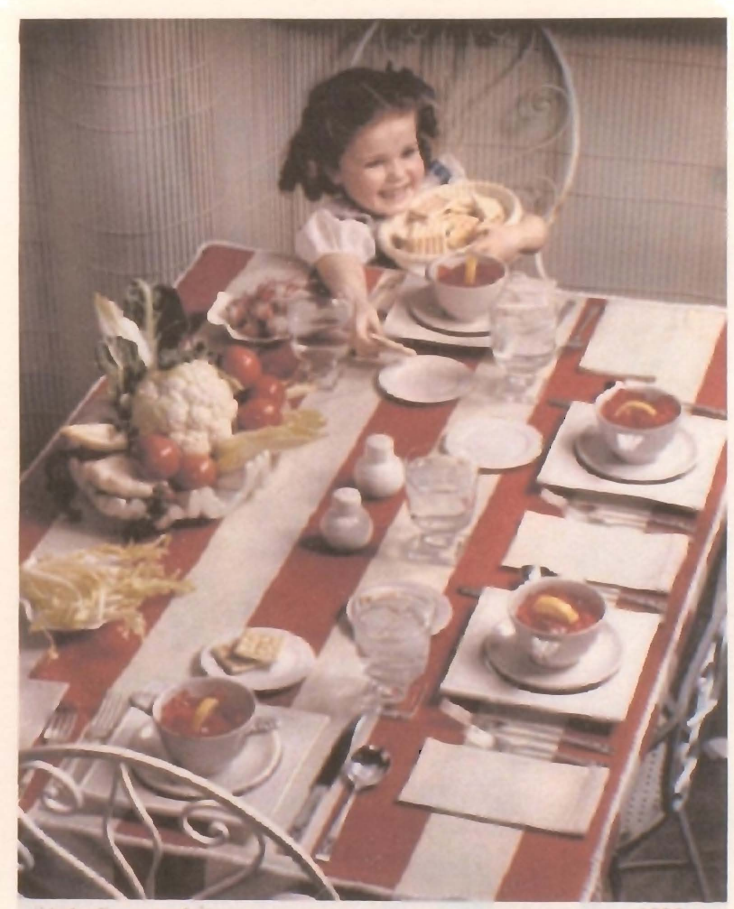

yot the wats

Homemaking

Published July 1939 


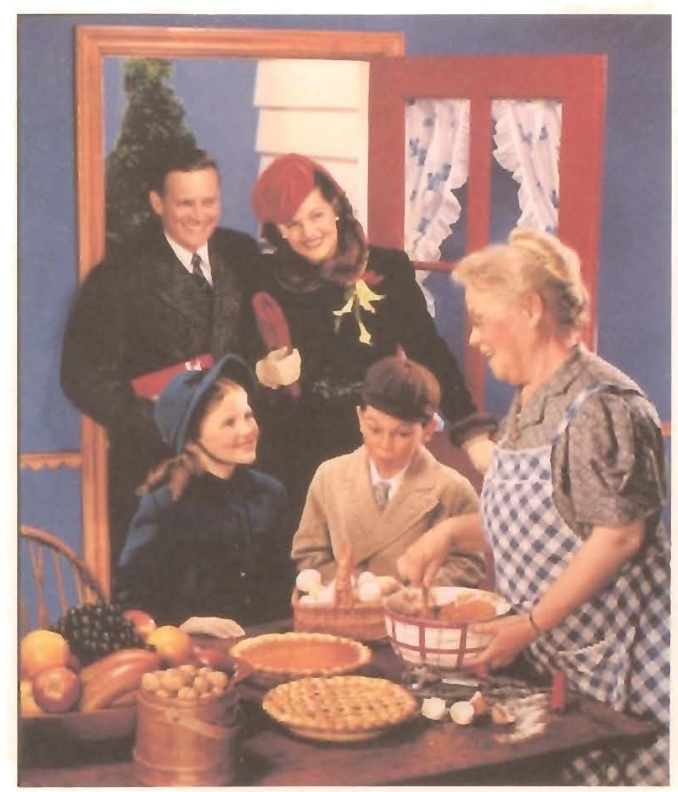

Homemaking

Published November 1939

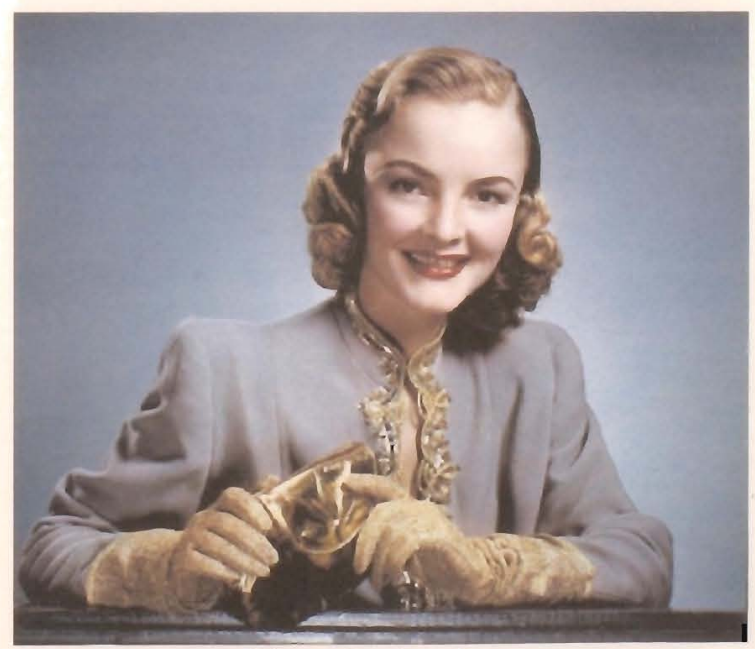

[frontispiece]

Published March 1940

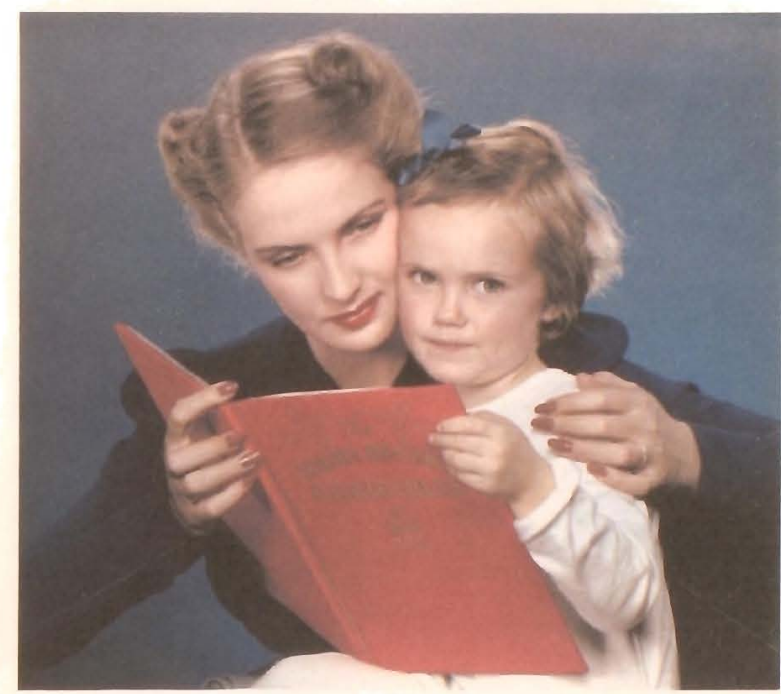

[frontispiece]

Published January 1940

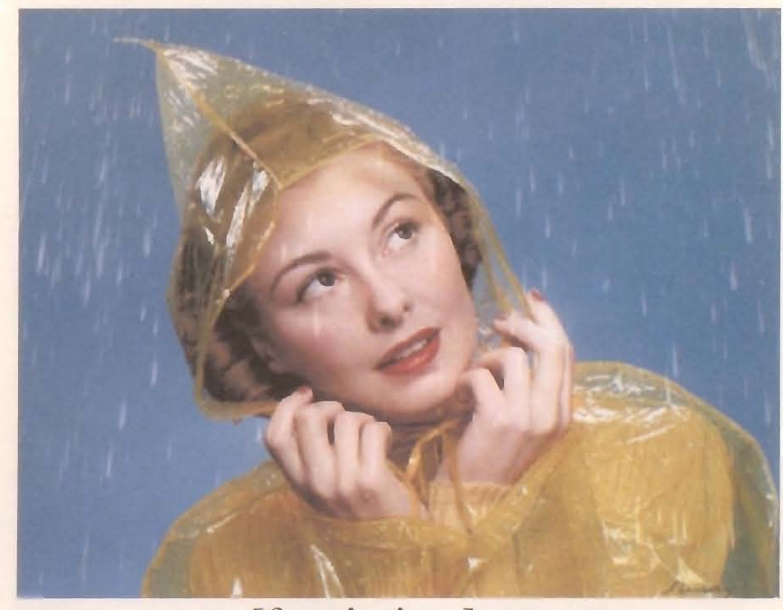

[frontispiece]

Published April 1940 


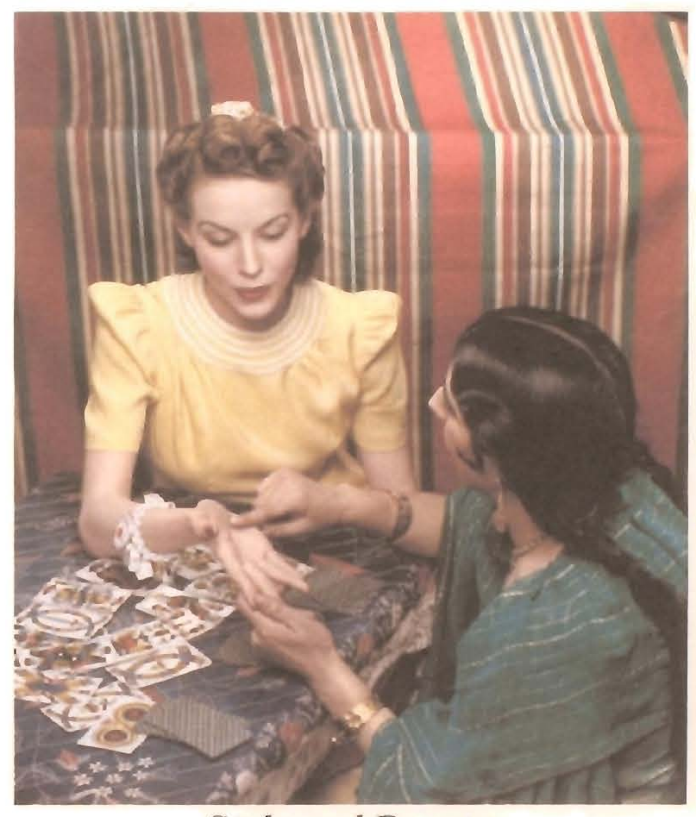

Style and Beauty

Published August 1940

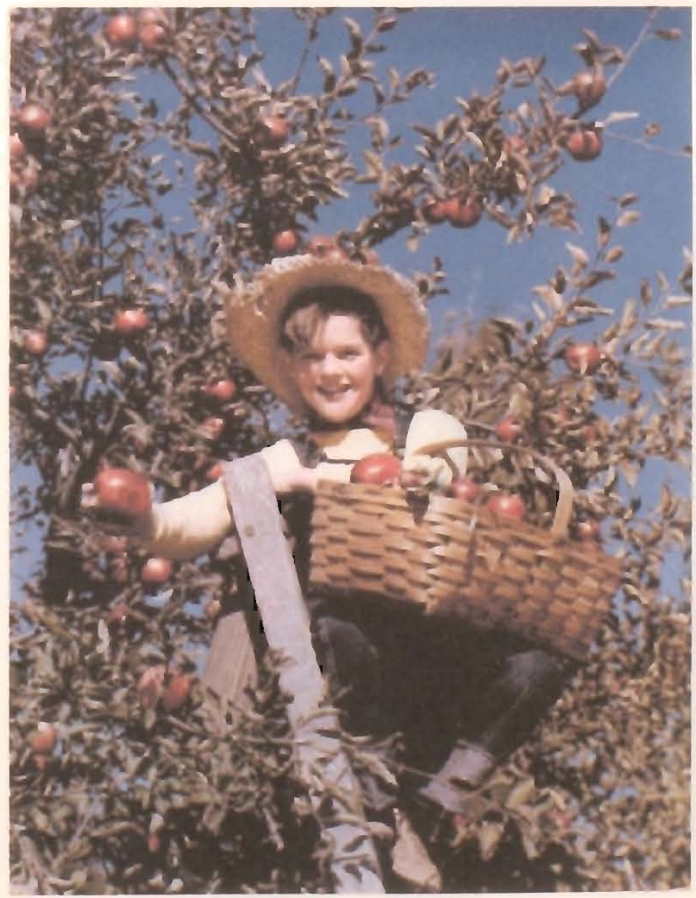

Homemaking

Published October 1940

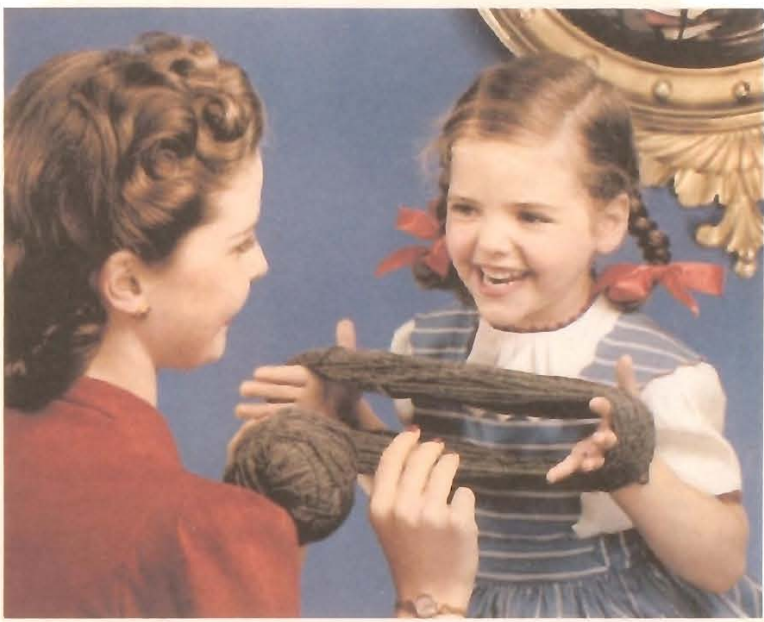

[frontispiece]

Published October 1940

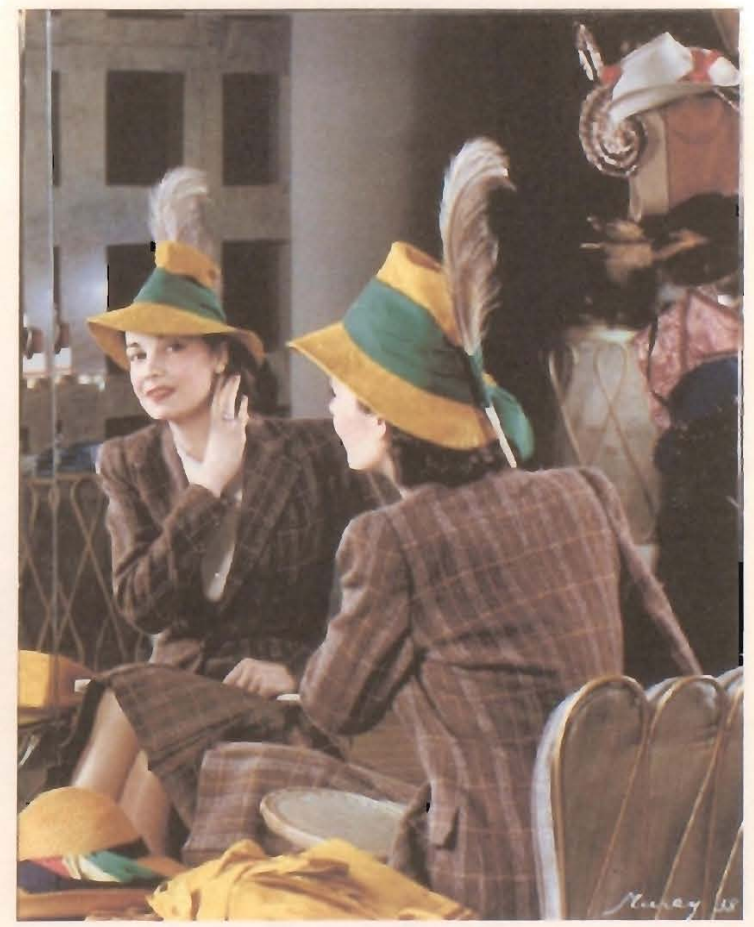

Style and Beauty

Published October 1940 


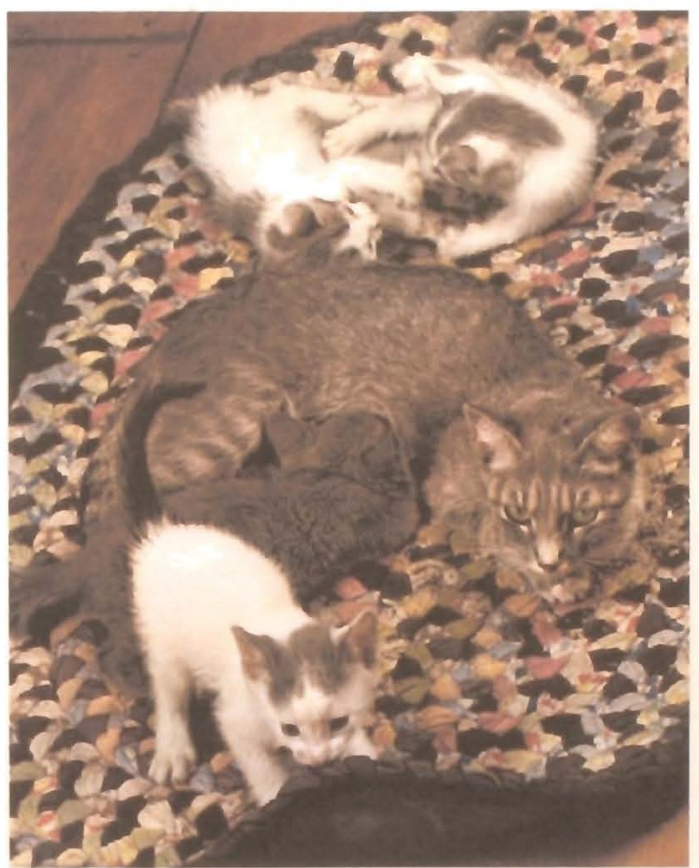

Homemaking

Published January 1941

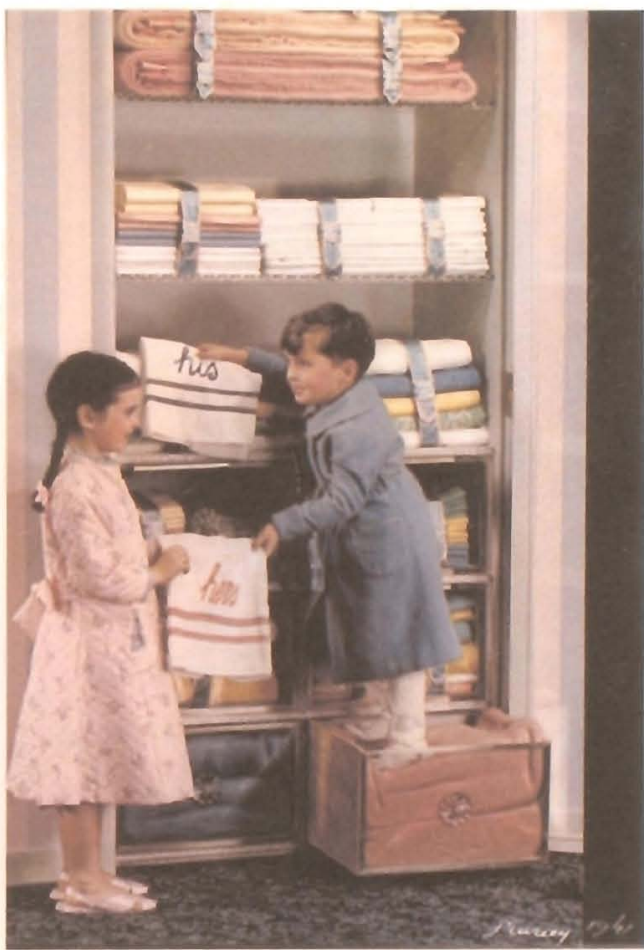

Homemaking

Published February 1941

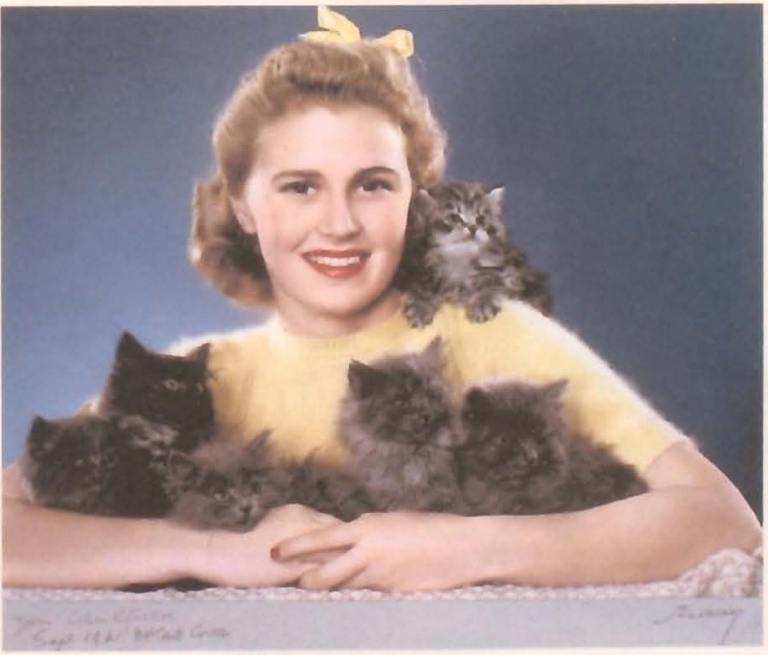

[frontispiece]

Published September 1941

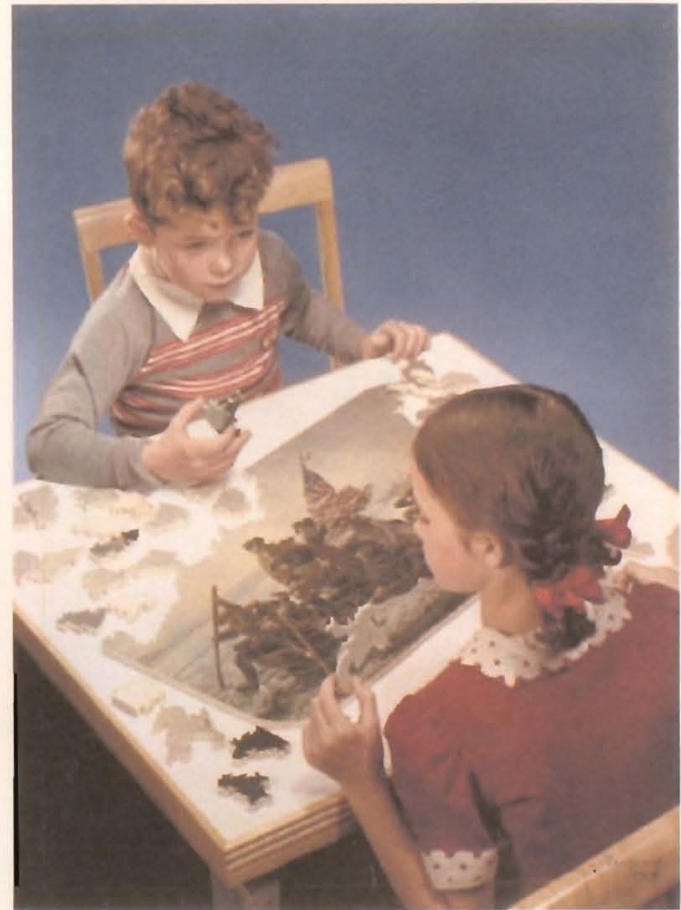

Homemaking

Published February 1942 


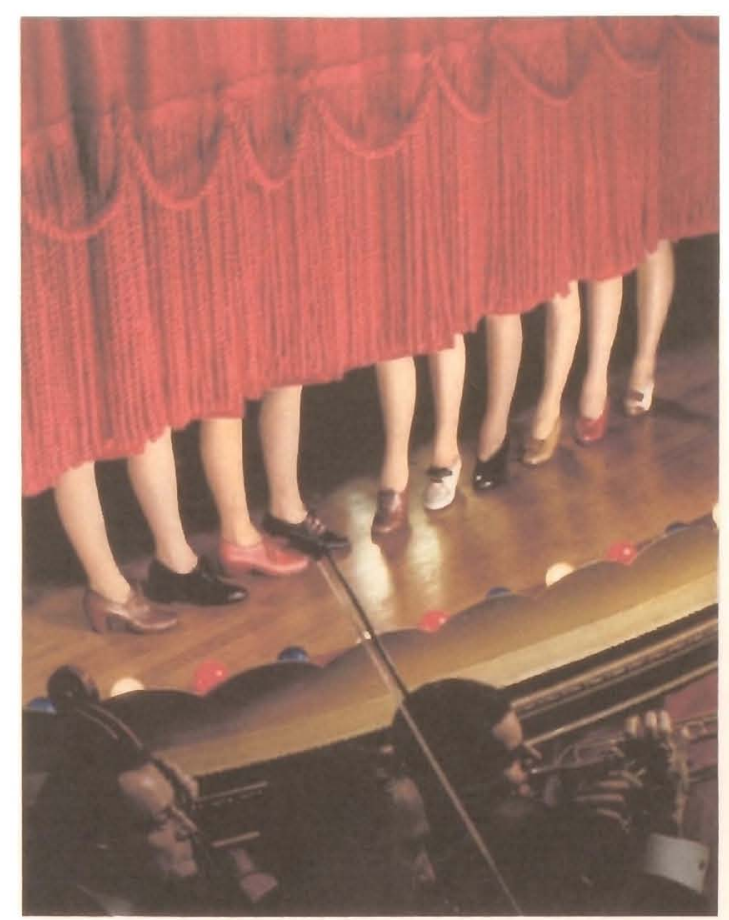

Style and Beauty

Published March 1942

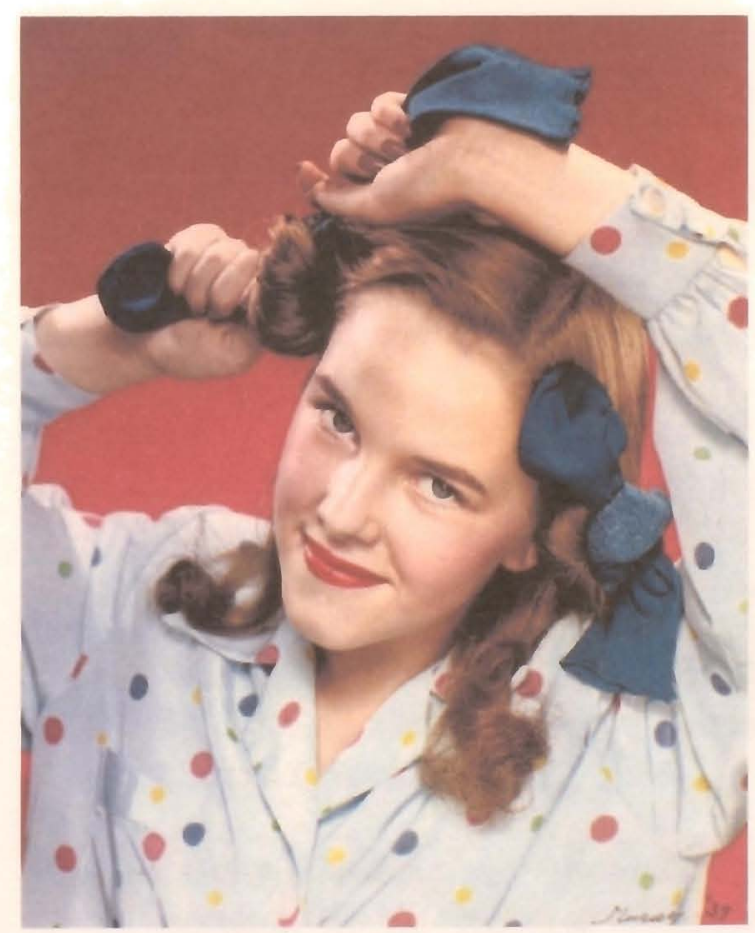

Style and Beauty

Published April 1944

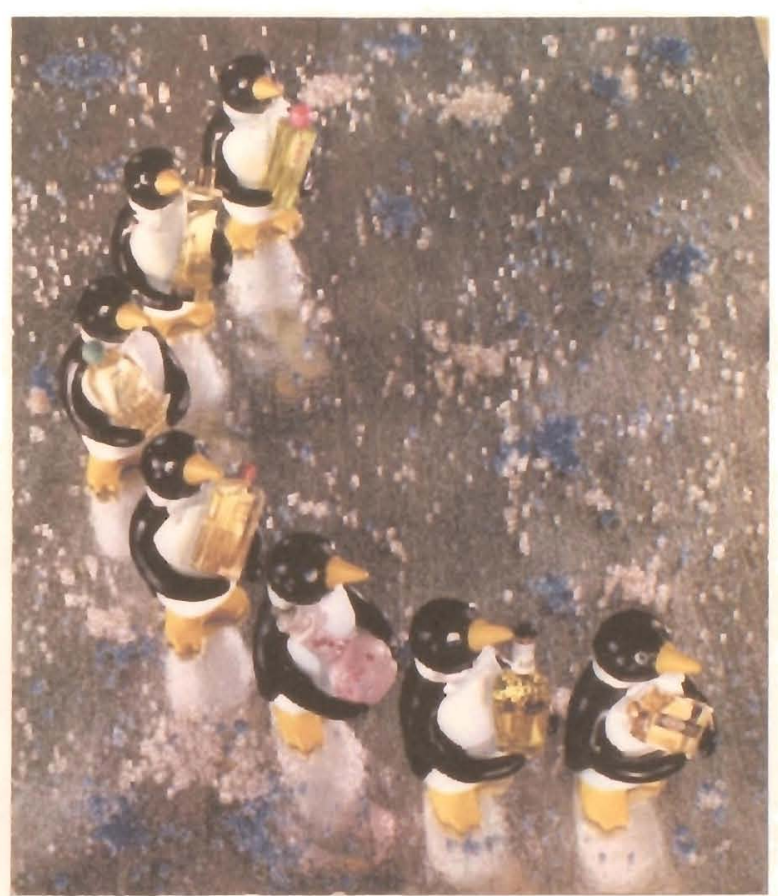

Style and Beauty

Published August 1943 


\section{Bibliography}

Anderson, Karen. Changing Woman: A History of Racial Ethnic women in Modern America. New York and Oxford: Oxford University Press, 1996.

Beekman, Daniel. The Mechanical Baby: A Popular History of the Theory and Practice of Child Raising. Westport: Connecticut: Lawrence Hill \& Company, 1977.

Bowlby Rachel. Carried Away: The Invention of Modern Shopping. New York: Columbia University Press, 2001.

Brumberg, Joan Jackobs. The Body Project: An Intimate History of American Girls. New York: Random House, 1997.

Coontz, Stephanie. Marriage, A History: From Obedience to Intimacy or How Love Conquered Marriage. New York: Viking, 2005.

- The Way We Never Were: American Families and the Nostalgia Trap. New York: BasicBooks, 1992.

Etcoff, Nancy. Survival of the Prettiest: The Science of Beauty. New York: Anchor Books, 1999.

Douglas, Susan J. Where the Girls Are: Growing Up Female with the Mass Media. New York: Three Rivers Press, 1995.

Ferguson, Marjorie. "Imagery and Ideology: The Cover Photographs of Traditional Women's Magazines," in Hearth and Home: Images of Women in the Mass Media. Eds. Gaye Tuchman, Arlene Kaplan Daniels and James Benét. New York: Oxford University Press, 1978.

Freidan, Betty. The Feminine Mystique. Introduction by Anna Quindlen. New York and London: W. W. Norton \& Company, 2001.

Grimberg, Salomon. I Will Never Forget You: Frida Kahlo and Nickolas Muray. San Francisco: Chronicle Books, 2004. 
Hine, Thomas. I Want That: How We All Became Shoppers. New York: HarperCollins, 2002.

Horowitz, Roger and Arwen Mohun. eds. His and Hers: Gender Consumption and Technology. Charlottesville and London: University of Virginia, 1998.

Illick, Joseph E. American Childhoods. Philadelphia: University of Pennsylvania Press, 2002.

Johnston, Patricia. Real Fantasies: Edward Steichen's Advertising Photography. Berkley: University of California Press, 1997.

Keppler, Victor. The Eighth Art: A Life of Color Photography. London: Chapman, 1939.

Klaffke, Pamela. Spree: A Cultural History of Shopping. Vancouver: Arsenal Pulp Press, 2003

Kitsch, Carolyn. The Girl on the Magazine Cover: The Origins of Visual Stereotypes in American Mass Media. Chapel Hill and London: University of North Carolina Press, 2001.

Kleinberg, S. J. Women in the United States, 1830-1945. New Brunswick, New Jersey: Rutgers University Press, 1999.

Lears, Jackson. Fables of Abundance: A Cultural History of Advertising in Modern America. New York: Basic Books, 1994.

Marchand, Roland. Advertising the American Dream: Making Way for Modernity, 19201940. Berkley, Los Angeles and London: University of California Press, 1985.

Mott, Frank Luther. A History of American Magazines. Cambridge, Massachusetts: Harvard University Press, 1970.

LaRossa, Ralphe. The Modernization of Fatherhood: A Social and Political History. Chicago and London: University of Chicago Press, 1997.

Mathews, Glenna. "Just a Housewife:" The Rise and Fall of Domesticity in America. New York and Oxford: Oxford University Press, 1987.

Matthews, Jean V. The Rise of the New Woman: The Women's Movement in America, 1875-1930. The American Way Series. Chicago: Ivan R. Dee, 2003.

Ohmann, Richard. Selling Culture: Magazines, Markets, and Class at the Turn of the Century. London and New York: Routledge, 1995, 
Reichert, Tom. The Erotic History of Advertising. Amherst, Yew York: Prometheus Books, 2003.

Scanlon Jennifer. Inarticulate Longings: Ladies' Home Journal, Gender, and the Promises of Consumer Culture. New York and London: Routledge, 1995.

Scanlon, Jennifer ed, The Gender and Consumer Culture Reader. New York: New York University Press, 2000.

Sivulka, Juliann. Soap, Sex and Cigarettes: A Cultural History of American Advertising. New York: Wadsworth Publishing Company, 1998.

Sobieszek, Robert. The Art of Persuasion: A History of Advertising Photography. New York: Harry N. Abrams, 1998.

Stein, Sally A. "The Rhetoric of the Colorful and the Colorless: American Photography and Material Culture between the Wars" PhD diss., Yale University, 1991.

Strausser, Susan. Never Done: A History of American Housework. New York: Henry Holt, 2002.

Schwartz, Ruth Cowan. More Work For Mother: The Ironies of Household Technology from the Open Hearth to the Microwave Oven. New York: Basic Books, 1983.

Walker, Nancy A. Shaping Our Mother's World: American Women's Magazines. Jackson, Mississippi: University of Mississippi, 2000.

Wolf, Naomi. The Beauty Myth: How Images of Beauty Are Used Against Women. New York: W. Morrow, 1991.

Zuckerman, Mary Ellen. A History of Popular Women's Magazines in the United States, 1792-1995. New York and Oxford: Oxford University Press, 1991. 